\title{
Dundrennan Abbey
}

\section{Archaeological investigation within the south range of a Cistercian house in Kirkcudbrightshire (Dumfries \& Galloway), Scotland}

\author{
by Gordon Ewart \\ Kirkdale Archaeology, 4 Western Terrace, Murrayfield, \\ Edinburgh EH12 5QF, Scotland
}

with contributions by S Carter, R Céron Carrasco, N Crowley, A Dunn, H Kenward, C Mills, T O'Sullivan, A Radley, D Rankin, B Will and GeoQuest Associates, and illustrations by D Connolly 
Published by the Society of Antiquaries of Scotland with Historic Scotland

Editor and the Council for British Archaeology

Internet version produced by

Archetype Information Technology Ltd, www.archetype-it.com

ISBN: 0903903709

ISSN: $1473-3803$ 


\section{Contents}

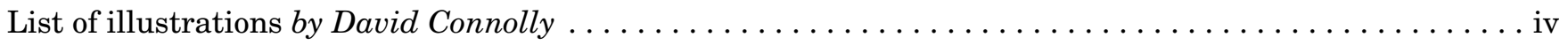

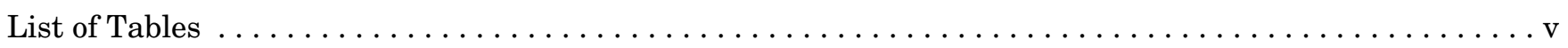

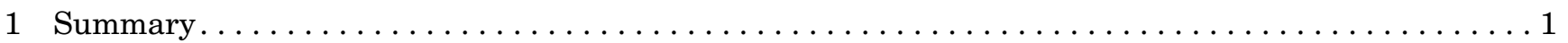

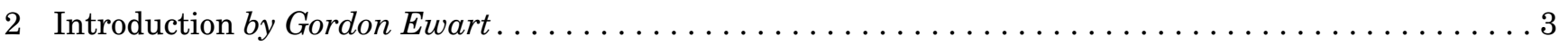

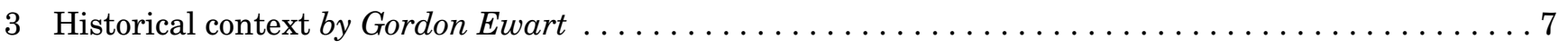

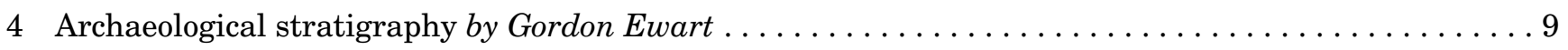

5 Geophysics and trial trenches by Gordon Ewart with GeoQuest . . . . . . . . . . . . . . . . 37

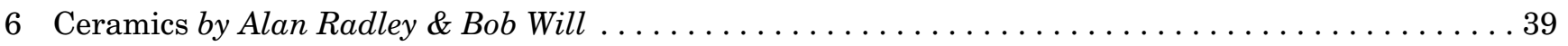

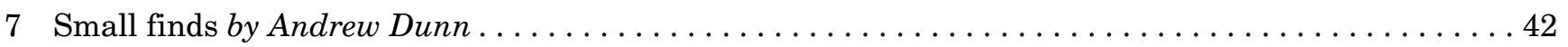

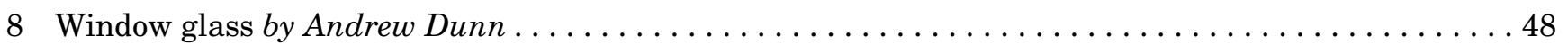

9 Architectural fragments by Andrew Dunn . . . . . . . . . . . . . . . . . . . . . . . . 50

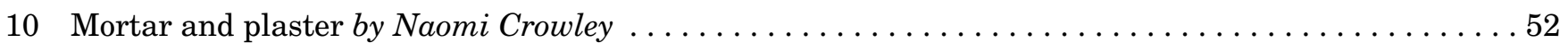

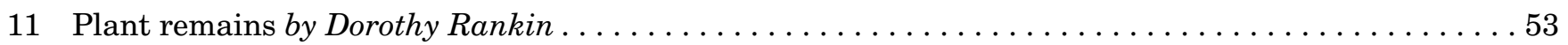

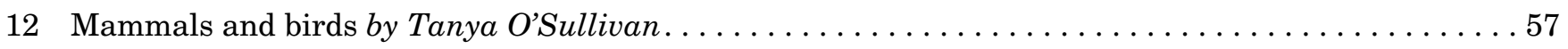

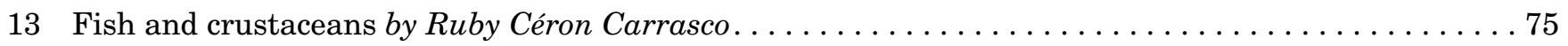

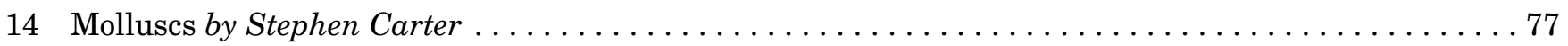

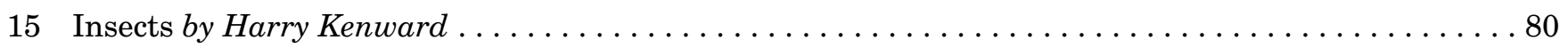

16 Burnt fuel remains by Ruby Céron Carrasco \& Coralie Mills . . . . . . . . . . . . . . . . . . . . . 81

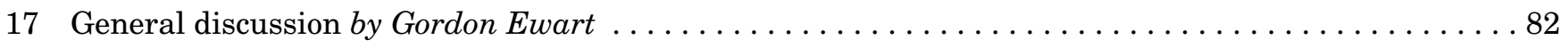

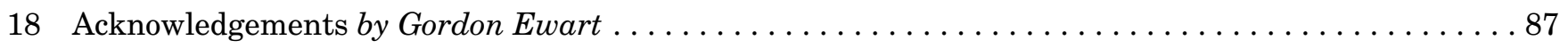

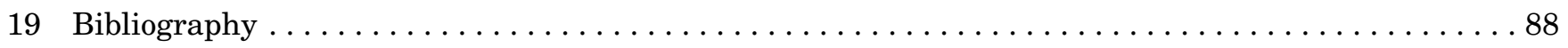

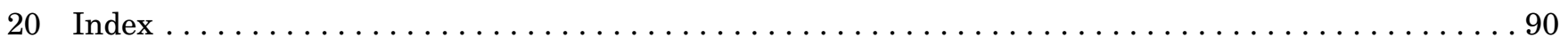




\section{List of illustrations}

Site location map (Based on the Ordnance Survey map (c) Crown copyright). . . . . . . . . . . 2

View of the site from south-east . . . . . . . . . . . . . . . . . . 3

Dundrennan Abbey and environs (Based on the Ordnance Survey of 1908) . . . . . . . . . . . 4

Room 4 under excavation, from west. . . . . . . . . . . . . . . . . 5

Principal rooms of the abbey and the area of excavation $\ldots \ldots \ldots$

Periods I and II . . . . . . . . . . . . . . . . . . . . . . 10

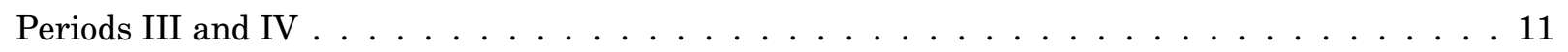

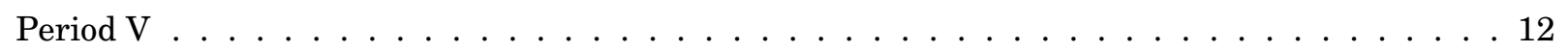

The excavation area, all periods, showing doorways mentioned in the text $\ldots \ldots \ldots$

Period I features . . . . . . . . . . . . . . . . . . . . . . . . . . 14

The great drain below a buttress (context 056 ), from east. . . . . . . . . . . . 15

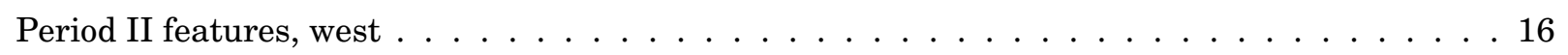

Period II features, east $\ldots \ldots \ldots \ldots \ldots \ldots \ldots \ldots \ldots \ldots$

Elevations of the west door room $5 / 6 \ldots \ldots \ldots \ldots \ldots$

Period III features, west. . . . . . . . . . . . . . . . . . . . . 21

Period III features, east . . . . . . . . . . . . . . . . . . . . . . 22

Elevation of the south façade of the room 4 and room $5 / 6$ complex $\ldots \ldots \ldots \ldots$

The south wall of room $5 / 6$, showing Period II and III buttresses. . . . . . . . . . . . . . 24

Elevation of the east-facing end-wall of Room $6 \ldots \ldots \ldots \ldots$

Period IV features, west. . . . . . . . . . . . . . . . . . . . . . . 27

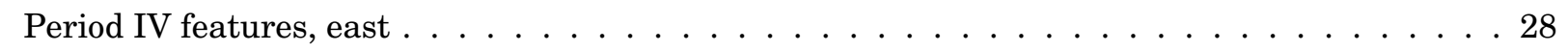

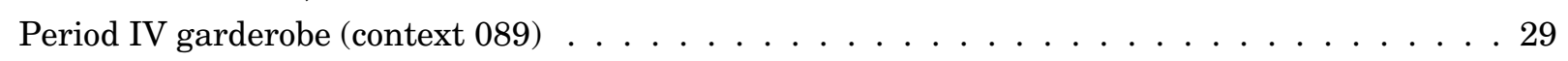

Period IV garderobe (context 090$) \ldots \ldots \ldots \ldots$

Re-used grave slabs over the great drain . . . . . . . . . . . . . . . . . 30

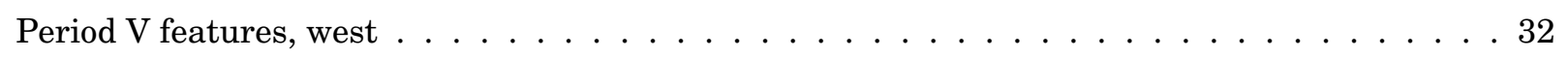

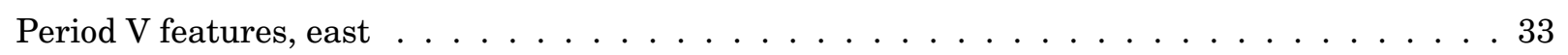

Midden group, plans and section . . . . . . . . . . . . . . . . . $\ldots 34$

Great drain fills . . . . . . . . . . . . . . . . . . . . . . 35

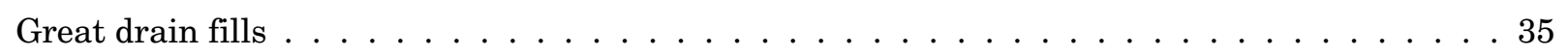

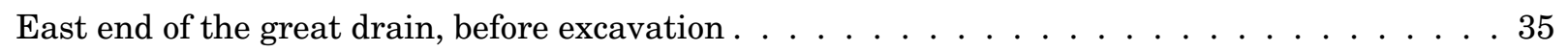

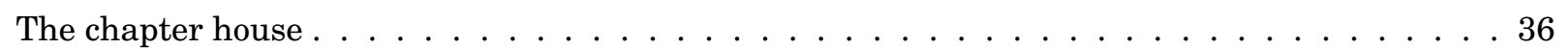

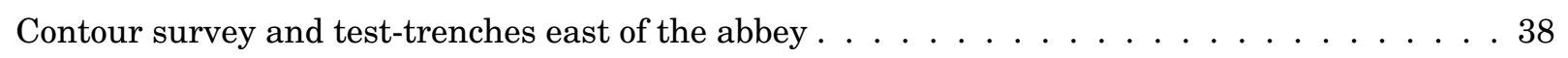

Pie-chart of ceramic sherds by period. . . . . . . . . . . . . . . . 40

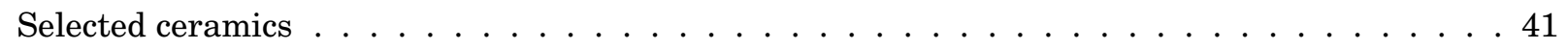

Silver spoon; copper-alloy fish-hook, needle \& pin . . . . . . . . . . . . . . . . . . 43

Compound ingot and iron belt loop . . . . . . . . . . . . . . . . . . . . . . . . . . .

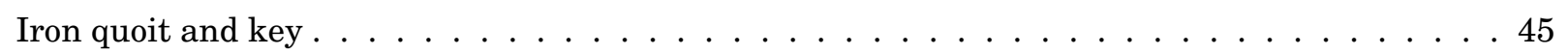

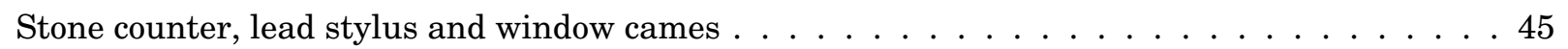

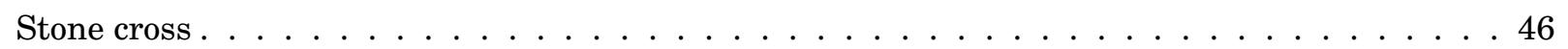

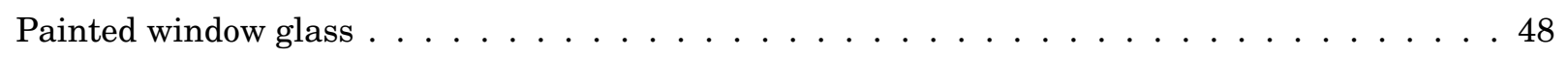

Masons' marks . . . . . . . . . . . . . . . . . . . . . . . . . . . . . . . . . . . 


\section{List of tables}

1 Architectural fragments: frequency of different elements in the assemblage . . . . . . . . 50

2 Type and frequency of masons' marks . . . . . . . . . . . . . . . . . . . . 50

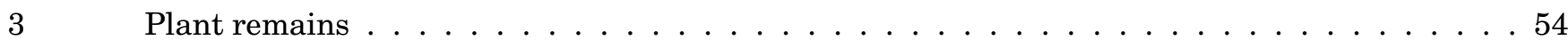

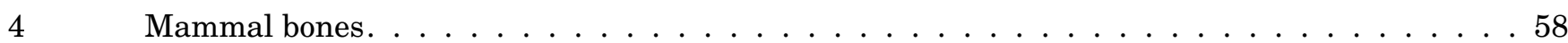

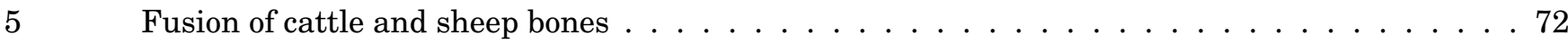

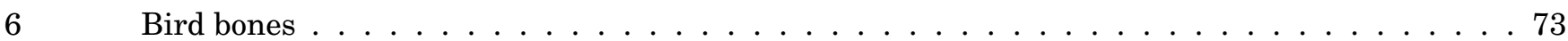

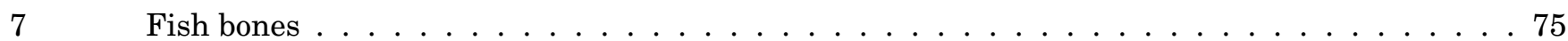

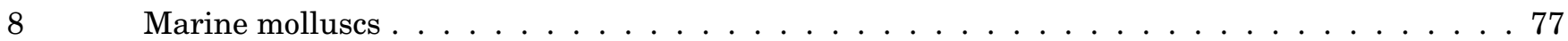

$9 \quad$ Non-marine molluses $\ldots \ldots \ldots \ldots \ldots \ldots \ldots \ldots$ 



\section{Summary}

The remains of the south-east corner of the 12thcentury Cistercian abbey cloister at Dundrennan (national grid ref: NX 7492 4750) were cleared of rubble and 19th-century landscaping infill over four seasons of fieldwork in the early 1990s. Elements of the warming house, novice's day room, great drain and latrine block undercroft were revealed. Coupled with a short programme of geophysical survey and test-trenching, new evidence of the sequence of building for the abbey was revealed by excavation. The project was funded by Historic Scotland. 


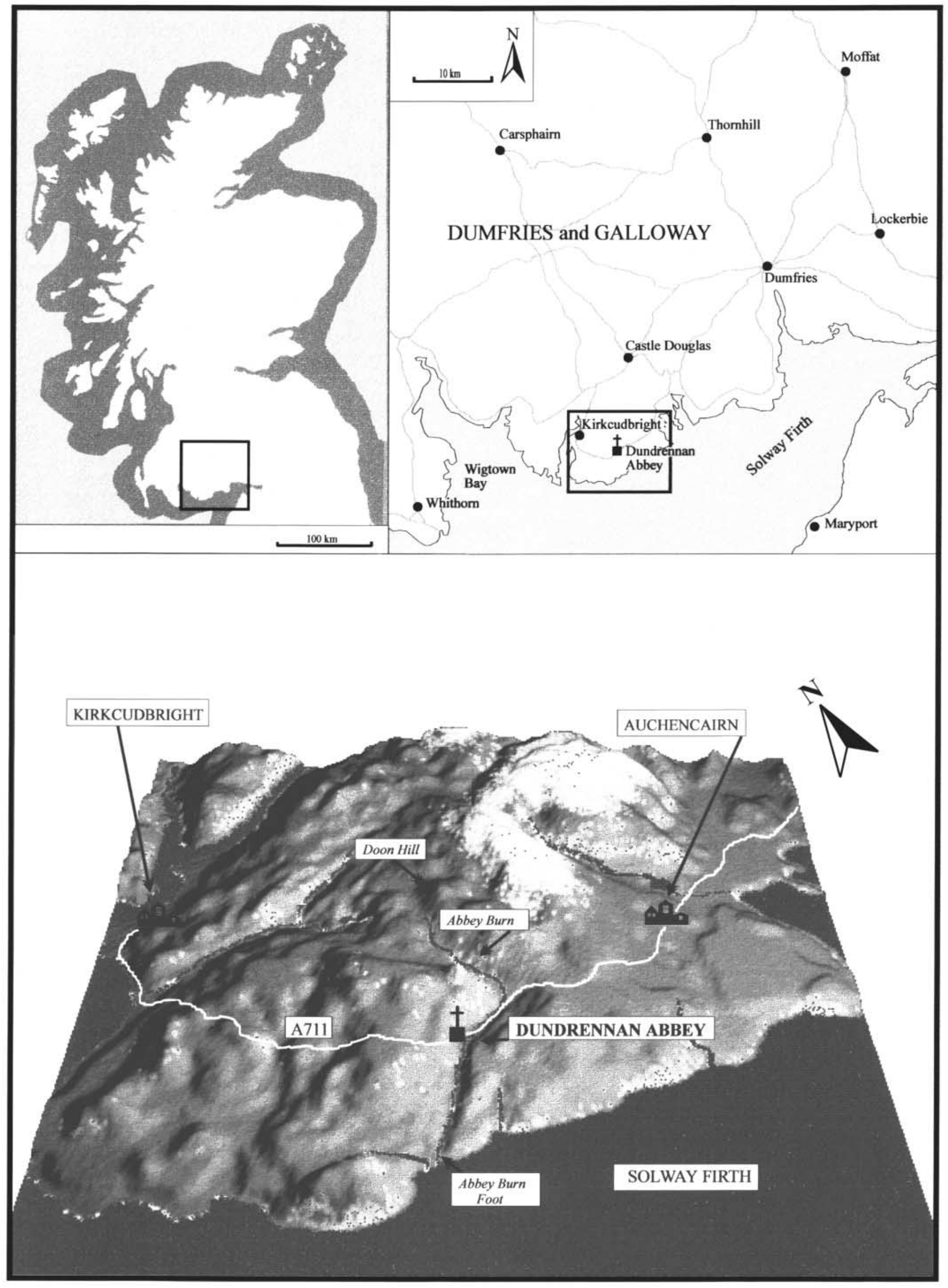

Illus 1 Site location map (Based on the Ordnance Survey map (C) Crown copyright) 


\section{Introduction by Gordon Ewart}

These broken arches and tottering columns - these deserted cells and weed-grown aisles - these neglected monuments of belted Knights and mitred Abbots (Thomson 1845, 358).

The extensive ruins of Dundrennan Abbey lie to the east of Dundrennan village, east of the A711, the road between Dalbeattie and Kirkcudbright (illus 1 ). The abbey buildings occupy an artificially enhanced terrace to the north and west of a sharp bend in the course of the Abbey Burn (illus $2 \&$ illus 3 ). The selection of this site exploited the naturally rising profile of the west side of the valley, as well as the lowest lying area of well drained ground within the valley. The A711 road and the present village of Dundrennan occupy a further terrace upslope from the abbey site, and define the likely maximum extent of the entire abbey precinct. The building in 1874 of the present manse, now a private house with gardens to the north and formerly an orchard to the west, saw the clearance of abbey structures towards the south-west of the complex. These post-medieval buildings towards the southern end of the abbey terrace appear to confirm the viable extent of ground suitable for building, and probably closely echo the locations of early ancillary structures to the south of the cloister itself.

The village and abbey occupy a wide area within the steep-sided valley of the Abbey Burn. Much of the cloister still survives alongside the abbey church, although many of the stone buildings have been robbed for local house building and drystone dyke construction. The south range however, prior to the recent programme of work, was virtually completely hidden, with only the doors from the cloister to the refectory, kitchen, warming house etc being visible within the area defined on the south side by a 19thcentury boundary wall separating the manse from the ruined abbey (illus 4 \& illus 5).

The typical criteria of well-drained, secluded, wooded valleys for Cistercian foundations of the $12 \mathrm{th}$ century are well met at Dundrennan. The sharp bend in the course of the Abbey Burn also provided suitable areas for cultivation to the east of the main abbey buildings, a further favourable condition for its foundation. The river drained the area of the abbey and adjacent fields, creating the potential for gardens and orchards, although the ground is prone to flooding. The supply of water to the abbey was probably via one of the known tributaries feeding

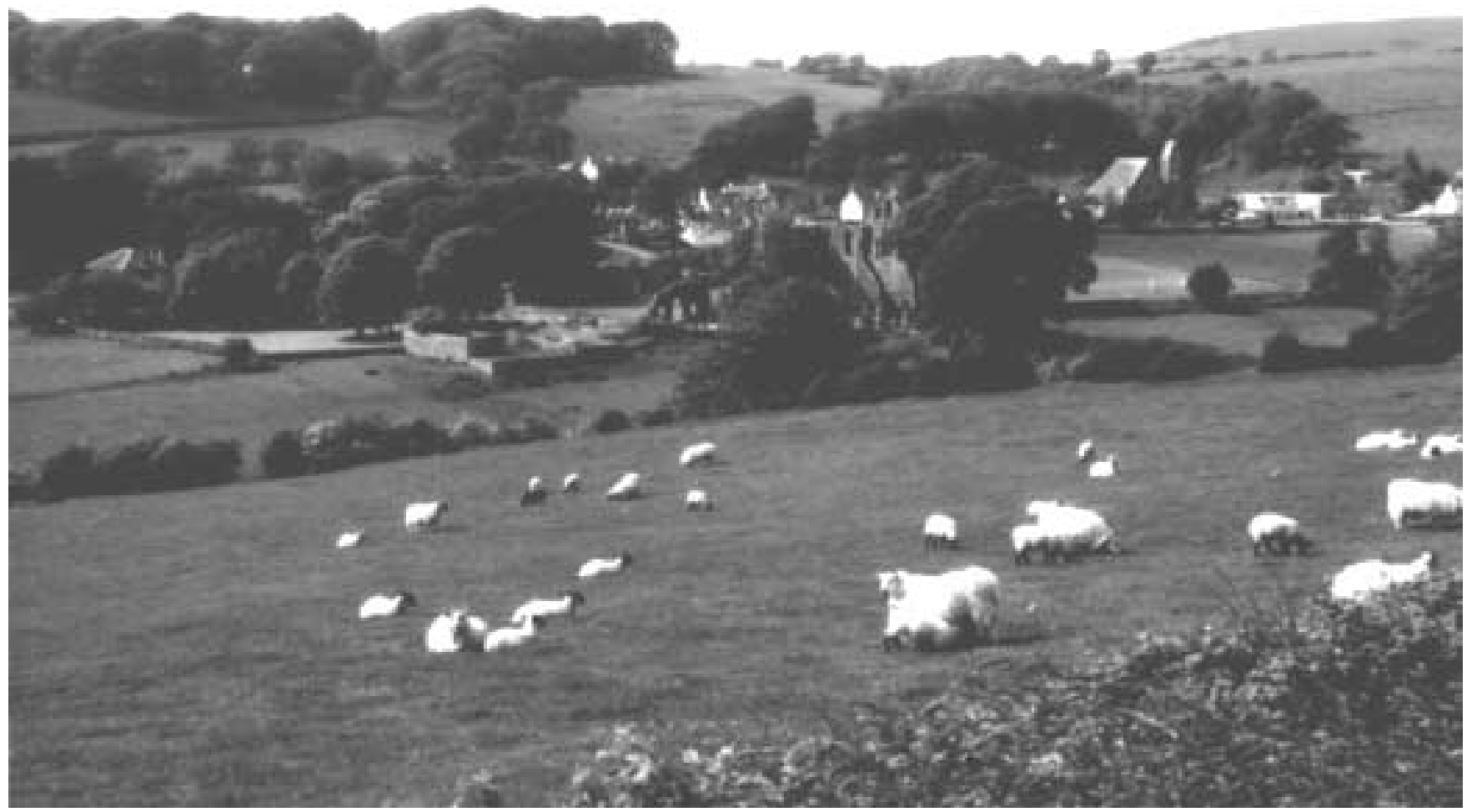

Illus 2 View of the site from south-east 


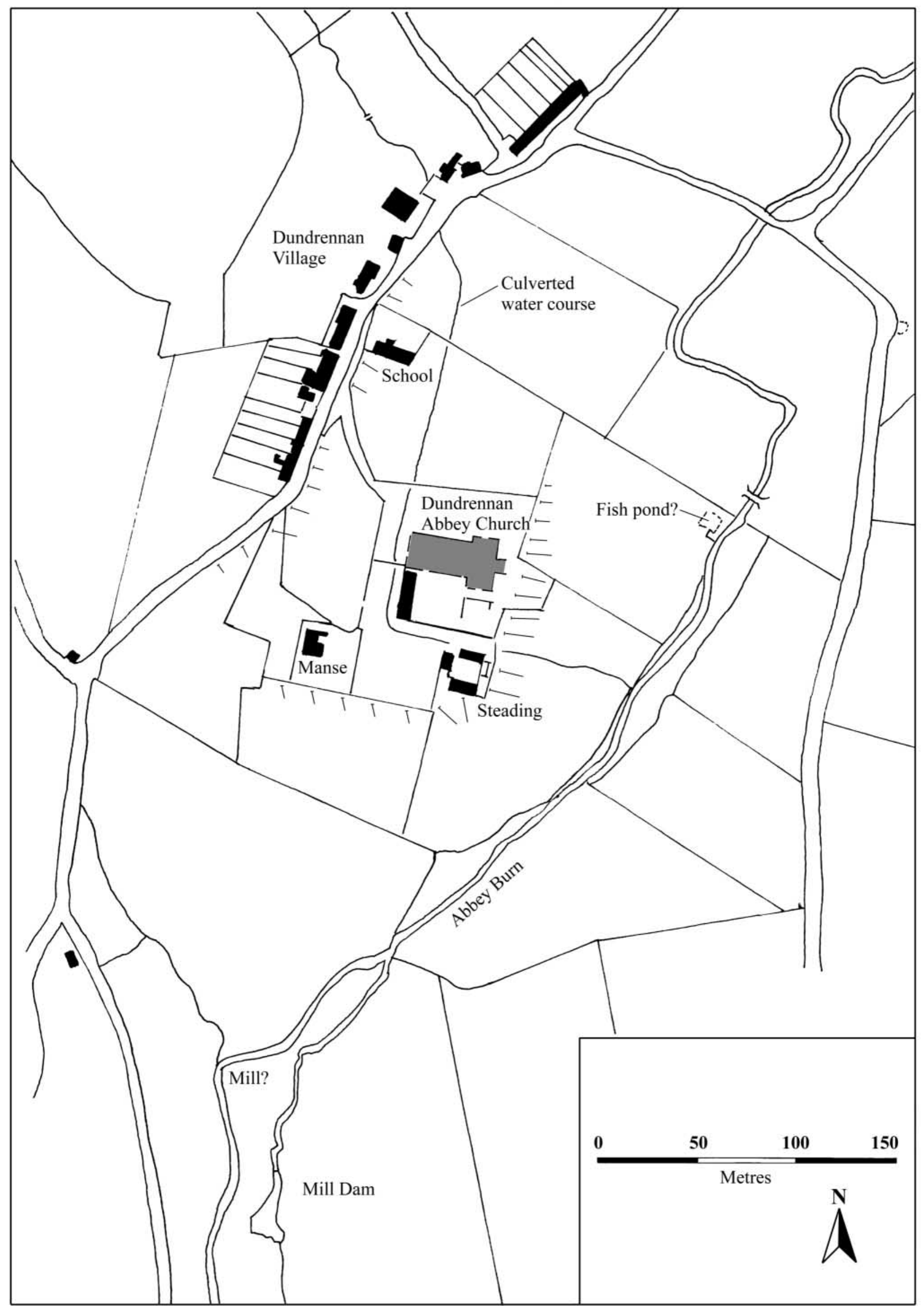

Illus 3 Dundrennan Abbey and environs (Based on the Ordnance Survey of 1908) 


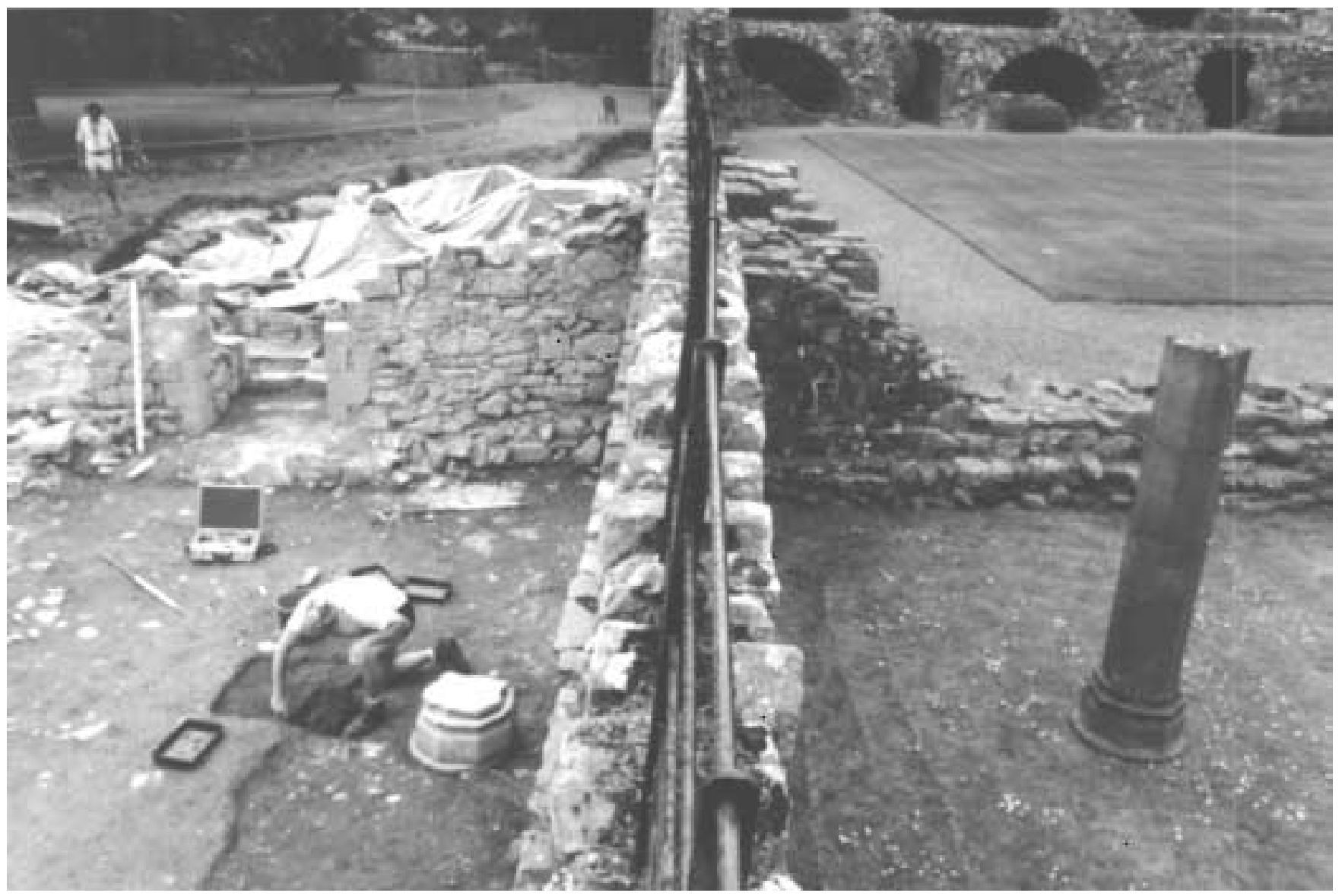

Illus 4 Room 4 under excavation, from west

into the Abbey Burn from the west. A culverted water course runs down towards the nearby site of the present school, and may well represent a freshwater supply to the abbey, now obscured.

The local topography is the result of a series of small river systems draining the granitic uplands, which form the promontory between Auchencairn Bay to the east and Kirkcudbright Bay to the west.
The Abbey Burn itself rises near Doon Hill, and flows past the abbey for a further distance of 2.4 $\mathrm{km}$ (1.5 miles) to the Solway Firth at Abbey Burn Foot. The shore around the mouth of the Abbey Burn was quarried to supply stone for some of the moulded elements of the monastic buildings, and the area formed a natural harbour, still used to the present day. 


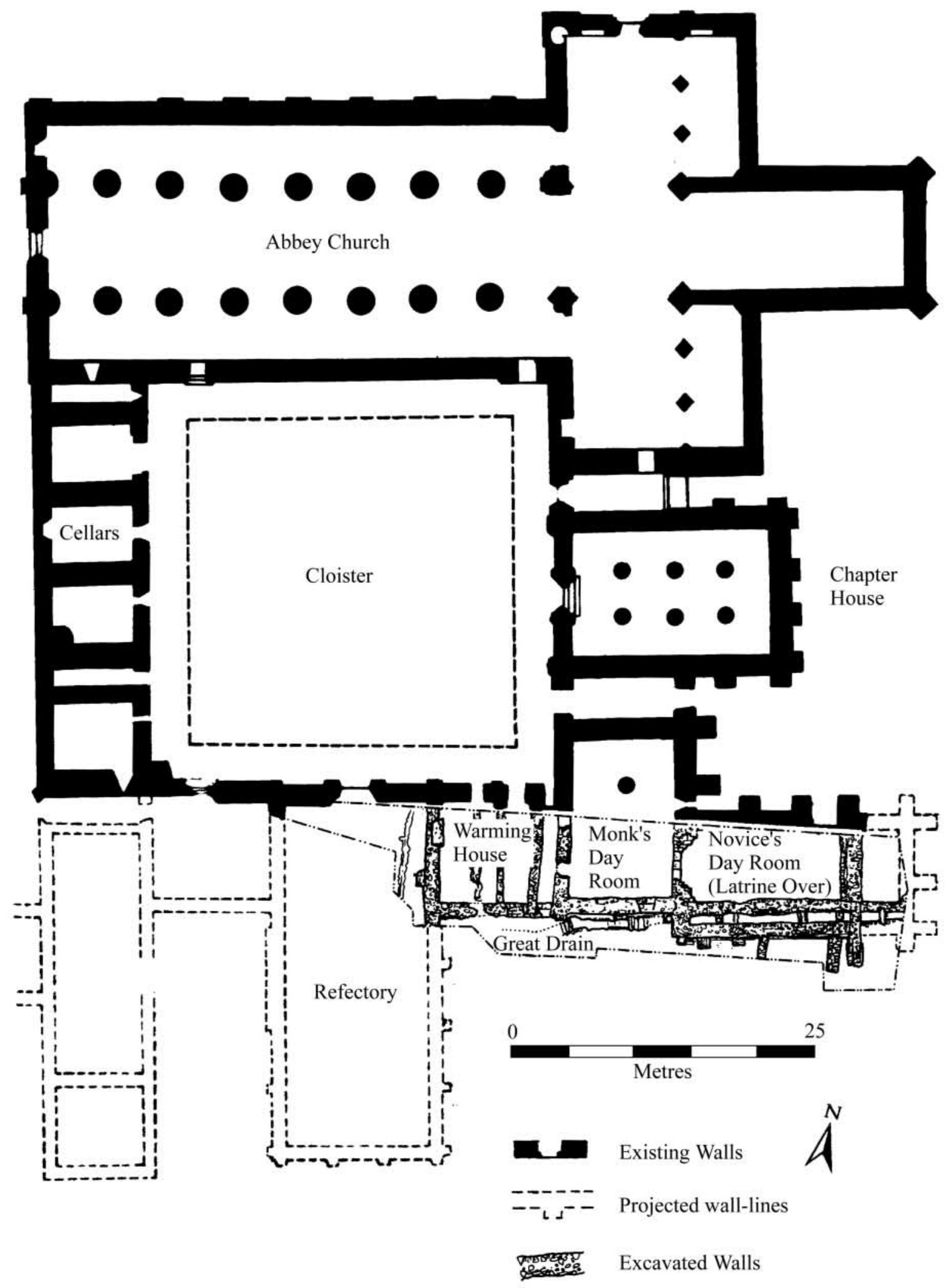

Illus 5 Principal rooms of the abbey and the area of excavation 


\section{Historical context by Gordon Ewart}

\subsection{Foundation and early history: motives and origins}

Dundrennan Abbey was founded by Fergus, Lord of Galloway, in 1142 as a daughter house of the Cistercian monastery of Rievaulx in North Yorkshire (Scott 1988). Unfortunately, there is no surviving monastic cartulary for Dundrennan and the sporadic references to the abbey in such sources as the Chronicle of Melrose (Stevenson 1991), the Life of Ailred (Daniel 1978) and records transcribed in the Calendar of Documents Relating to Scotland (Calendar) shed little light on its early history. However, there can be little doubt that Fergus' reasons in founding Dundrennan were, by and large, the same as those held by monastic patrons throughout medieval Christendom. In the 11th and 12th centuries monastic patronage offered the aristocratic benefactor both spiritual and temporal benefits. By supporting a particular house and monastic order a patron could seek to court the favour, and thus the support, of an important religious and political institution. No doubt this played some part in persuading Fergus to found a religious house in Galloway. In his choice of the Cistercian Order, however, it may be the case that he was following both royal example and acting in accordance with the persuasive influence of Archbishop Malachy, the papal legate of Ireland. One authority (Brooke 1994, 88-9) has suggested that the foundation of Dundrennan was a direct consequence of Archbishop Malachy's visit to Fergus in 1139. There can be little doubt that Malachy, a friend of Bernard of Clairvaux and a supporter of the Cistercians (as attested by his foundation of the Cistercian monastery of Mellifont in Ireland) must have advocated the cause of the white monks at Fergus' court and thus may have brought the Order to the Gallovidian ruler's attention. Additionally, Fergus may have had David I's Cistercian foundation of Melrose (founded in 1136) in mind when he in turn founded Dundrennan. After all, Fergus clearly considered himself a member of the highest ranking nobility in Scotland, even to the extent of styling himself Rex Galwitensium (ibid, 79) and it may be the case that he associated the Cistercian Order in particular with royal patronage. Whatever the case, the foundation represented the beginning of a dynamic relationship between the early medieval Lordship of Galloway and the Cistercian Order.

Fergus endowed Dundrennan with a massive landed estate which comprised the whole of what is now the parish of Rerrick. This core estate was supplemented by a series of smaller grants of land. The earliest reference to the demesne lands of the house dates to 1305. In that year Edward I of England confirmed the lands held by the monastery according to the charters granted by its founder and others. The lands were listed as follows :

Gairstange, Newelathe, Ouerlathe, Netherlathe, Aghengoile, Oure Reraik, Nethre Reraik, Roskerald, Aghencarne, Clonfinaghe, Barlocwod, Barlok, the isle of Estholm, the hospital of Crithe, Kirkpatrick Durand, and Aghenkippe in the county of Dunfres, and Biskeby and Culfaldan in the County of Wigton (Calendar II, no. 1702, 461).

Dundrennan also owned property in Ireland, which had been donated some time before 1286. An English document of 1328 related that the abbot of Dundrennan petitioned Edward III

at the request of the king of Scotland to restore their land of Bretneston in the county of Meath in Ireland, from which they were ejected when the war began, for no other reason than that they were Scots, as he is bound to do by the treaty (Calendar III, no. 969, 175).

As with other Cistercian houses the successful exploitation of the abbey's landed property was largely due to the order's use of lay monks or conversi as domestic and agricultural labourers on the estates. Thanks to the presence of a large number of conversi during the early years of the abbeys existence, the great estates of the house were successfully exploited and the community sustained. In Scotland the Cistercians were involved in sheep farming and wool production on a massive scale, which drew them into European markets (see 12. Mammals and birds). The monks of Dundrennan were also found trading in England in 1266:

[Henry III] at the instance of Sir John de Balliol, took under his protection, the Abbot, monks and friars of Dundreynan Abbey in Galloway and their men coming to England with wool and other goods to traffic therewith; and gives them leave to buy corn and other victuals there to take to Galloway for their sustenance, they paying the usual customs on the same (Calendar I, no. 2414, 479).

Similarly, in 1280 Edward I confirmed an earlier charter of 1267 whereby monks of Dundrennan travelling to Ireland were given permission to "buy to the extent of 240 crannocks of wheat and as many of oats or meal, wines, and other victuals for the sustenance of their house' (Calendar II, no. 182, 58). The Abbey was therefore linked to a complex European trade network, exporting wool and possibly wares produced in the abbey workshops and, in turn, 
importing grain from Ireland and wines from France.

Cistercian abbots were also important players in the field of local and European politics. Ailred of Rievaulx helped to pacify Fergus and his sons shortly after 1153 (Brooke 1994, 95-9), and the abbots of Dundrennan and Glenluce adopted a pro-Gallovidian stance in opposition to the leanings of the Scottish Crown during the ecclesiastical and political struggles following the death of Alan of Galloway and the Bishop of Whithorn in 1234 (ibid, 133-9). These episodes demonstrate the degree of political clout wielded by Cistercian abbots in the 12th and 13 th centuries.

The importance of Dundrennan among the Scottish Cistercian monasteries may be further inferred from the instances when abbots of Dundrennan were appointed to the abbacy of the mother house at Rievaulx. When Ailred of Rievaulx died in 1167, for example, he was succeeded as abbot by Sylvanus of Dundrennan; and similarly Roger of Rievaulx was succeeded by Leonius of Dundrennan in 1239 .

\subsection{Later history: commendators and ministers}

The success of the Abbey as the earliest and wealthiest Cistercian foundation in the region was not maintained into the later 13 th century, due primarily to the decline of the system of conversi. An indication of the mixed fortunes of the abbey during the 13th century survives in the form of petitions to the English Crown. In 1299 the community applied for compensation from Edward I after damage inflicted at the start of the Wars of Independence, and the English Crown was again petitioned in 1328 for the restoration of abbey lands in Ireland.

The history of subsequent years is largely obscure. By the mid 16th century the community of brethren was relatively small, numbering a single prior and nine monks in 1545. By 1565 Edward Maxwell, third son of Sir John Maxwell of Terregles, fourth Lord Herries, had been appointed commendator. Thus, by the immediate post-Reformation years, the superior was no longer a cleric and the demise of Dundrennan as a religious house was already well advanced. Under the Maxwells in this period Dundrennan served as the administrative centre for the old abbey estate and was maintained. Edward Maxwell received Mary Queen of Scots at Dundrennan in May 1568 before her departure to England (MacGibbon \& Ross 1896, vol. 1, 388). With the death of Maxwell, in 1598, the commendatorship passed to John Murray, ultimately Earl of Annandale. The abbey was made a temporal lordship in 1606 and what remained of its vast estate was bestowed on Murray. In 1621 Murray resigned and the abbey was eventually annexed to the deanery of the Chapel Royal, Stirling.

Part of the abbey church remained in use as a parish church until 1742. The abbey was robbed of stone for the construction of the Kirkcudbright Old Courthouse in 1642 and the site was regularly quarried throughout the 18th century. In 1789, Reverend William Robb described how the abbey 'was tore down to build the present manse and a large clauchan of houses beside it, built with freystones, and a gentleman's house close by' (Christie 1914, 92).

Interest in the site as a place of antiquity commenced with the initial clearance of the ruins on behalf of the Earl of Selkirk in 1838 (Christie 1914, 93-4). A more concerted programme of work commenced shortly after, when the then owner, Adam Maitland of Dundrennan, conveyed the abbey into the care of the state (NAS MW1/594). This was prompted primarily by concern for the safety and management of the ruined abbey, but also by an appreciation of its historical significance. By 1841 a boundary wall was established around the monument which in turn delimited the manse property from the cleared abbey structures. This arrangement survived until the recent programme of archaeological excavation on the south range, after which part of the wall between the manse and abbey was eventually removed (illus 4). The mid 19thcentury programme of rationalisation saw the demolition of buildings on the south side of the cloister in 1843 and a new manse was eventually built in 1874 , close to the site of its demolished predecessor. After 1906 the local Church of Scotland Minister, Reverend Alex Christie, embarked on an increasingly ambitious series of archaeological excavations on various parts of the abbey. This culminated between 1911 and 1914 with extensive work on the west range, chapter house and refectory (Christie 1914). 


\section{Archaeological stratigraphy by Gordon Ewart}

\subsection{Introduction}

The results of the excavations are described in terms of historic periods reflecting the building, occupation and abandonment of structures towards the east end of the south range (illus 5), from the later 12th century to the present time. The extent of archaeological investigation was limited by available resources, and consequently relatively few of the deposits associated with the active use of the abbey in this part of the site were excavated. The majority of the deposits which were excavated reflected the impact of the construction of the post-Reformation manse and the landscaping of the heavily robbed abbey buildings during the 19th century. The evidence for the sequence of building and occupation from the late 12th century onwards lies primarily in the analysis of the standing building sequence, with specific detailed, stratified information emerging from certain key areas. These comprise:

- Foundation, levelling and infill deposits associated with room 8, the warming house (illus 6)

- Midden deposits over the re-aligned great drain outside the novice's day room (illus 5 \& illus 27)

- The contents of the great drain at its junction with the latrine block (illus 5 \& illus 27)

In total, five periods of building, occupation and abandonment of the structures at the south-east corner of the cloister were identified, and the archaeological account is presented in these terms. In addition, a period of activity spanning Periods IV and $\mathrm{V}$ was identified from the deposits within the great drain, and overlying it:

- Period I: $c$ 1170-1230

- Period II: $c$ 1230-1320

- Period III: $c$ 1320-1450

- Period IV: $c$ 1450-1520

- Period V: $c$ 1520-1600

- Occupation over Periods IV-V: the midden and the great drain fills

The standard Cistercian abbey plan, as represented at Dundrennan, alongside the names of various abbey structures, is given in illus 5 .

\subsection{Period I: c 1170-1230}

Period I covers the lengthy programme of construction involving the initial colonisation of the site and the establishment of the principal elements of the claustral circuit. Despite the duration of this initial occupation phase, only fragmentary evidence was revealed pre-dating the more extensive building campaign of Period II. Evidence of Period I structures revealed by excavation (illus 6) comprised the refectory (room 11), the warming house (room 8) and a temporary wooden structure (structure 13). Evidence of crude, robbed walls suggested the presence of early, smaller versions in stone of the fully defined Period II south range. This confirmed the typical progression of building around the completed cloister, with the establishment of the key components to the north, then east and south - namely the church itself, the chapter house and the refectory, albeit in simpler forms.

Accommodation for the community and its guests, as well as for their stores and other basic requirements, was also presumably in place, although whether within temporary timber buildings or as part of the simpler stone buildings of Period I is not known.

Evidence of the division between the refectory (room 11) and the warming house (room 8) was revealed, suggesting that separate structures were in place prior to the Period II remodelling. The south walls of room 8 and room 11 were further defined by the line of the monastery's great drain. This ran west/east immediately adjacent to the south range. The fragmentary evidence for a timber building, structure 13, confirms that some buildings of this sort were present at an early date. This was subsequently dismantled and the remains buried. Perhaps significantly, structure 13 lay outside the limits of the south range.

\subsubsection{Structure 13 (illus 6 \& illus 10)}

A trench measuring $3 \mathrm{~m} \times 1 \mathrm{~m}$ was excavated immediately south of the remnant north wall of the 19thcentury stables and steading (illus 3 ) to assess the extent of archaeological survival beneath the stable yard, prior to the consolidation of the steading complex. Part of a steep-sided, linear feature (context 100) with crudely pitched sandstone slabs at its base was found running east/west at the extreme south end of the trench. The presence of pitched stones with vertical sides within a shallow ditch was reminiscent of timber-beam and post-frame wall construction, the wall fabric being represented by the quantities of rubble and clay at the foot of the feature. The feature itself was up to $500 \mathrm{~mm}$ deep, and pottery from its fill (context 101) suggested that it had been backfilled by the mid 14th century (see 6 . Ceramics). The fill of the linear feature indicated that water found its way along the defile left by the 
Period I Abbey plan (1170 to circa 1230)

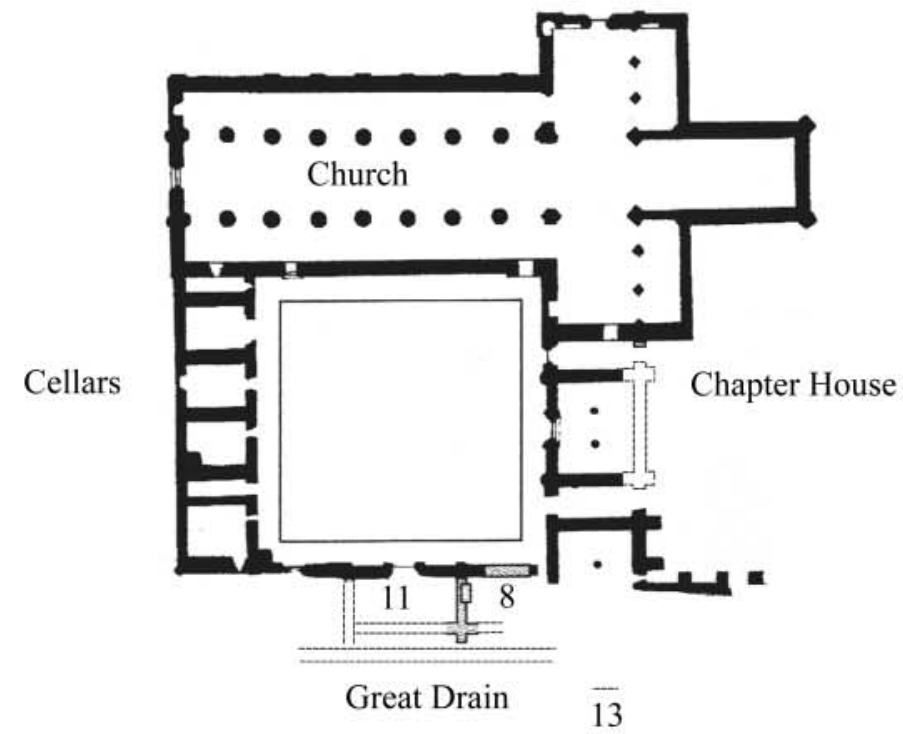

Key:

8 - Warming house

11 - Refectory

13 - Site of Structure 13

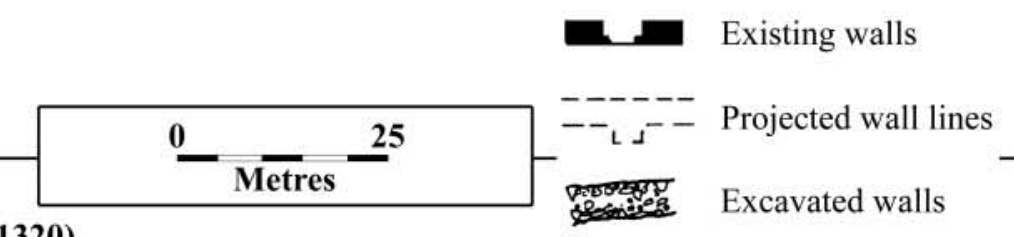

Period II (circa 1230 to 1320)

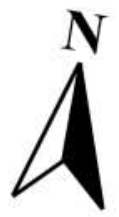

Key:

4 - Monk's day room

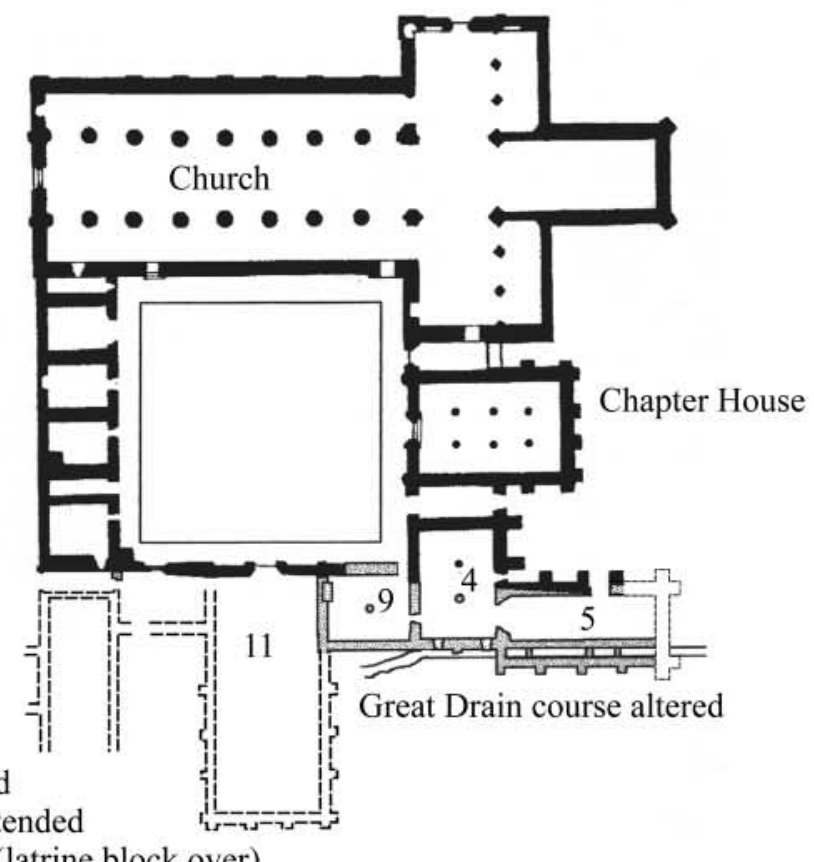

9 - Warming house extended

5 - Novice's day room (latrine block over) 
Key:

10 - Warming house

11 - Refectory

12 - Room 12

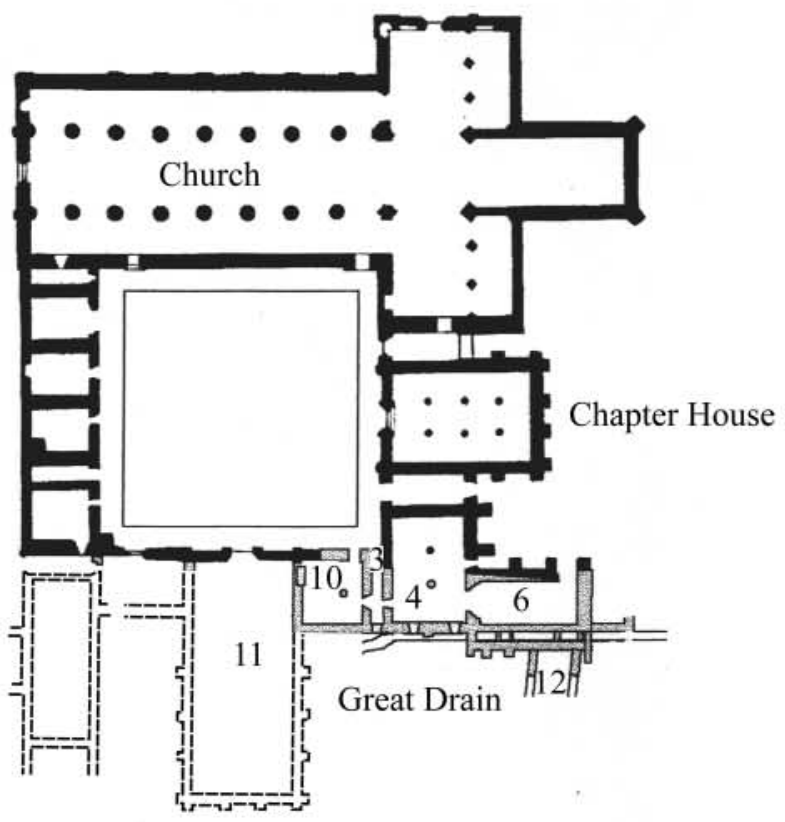

$\stackrel{N}{N}$

3 - Day Stair

4 - Monk's day room

6 - Novice's day room (latrine block over)

Existing walls

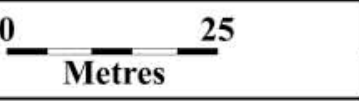

Excavated walls

Key:

1 - Room 1

2 - Room 2

3 - Day stair

4 - Monk's day room

6 - Novice's day room

7 - Room 7

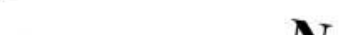

11 - Refectory

12 - Room 12

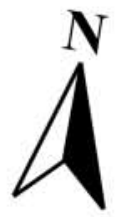

Church

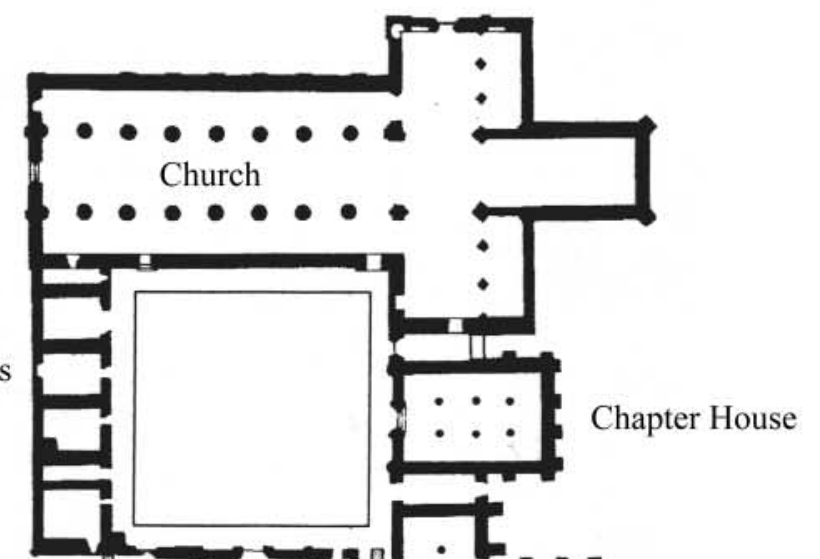

11

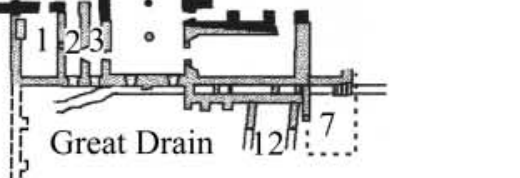

Illus 7 Periods III and IV 


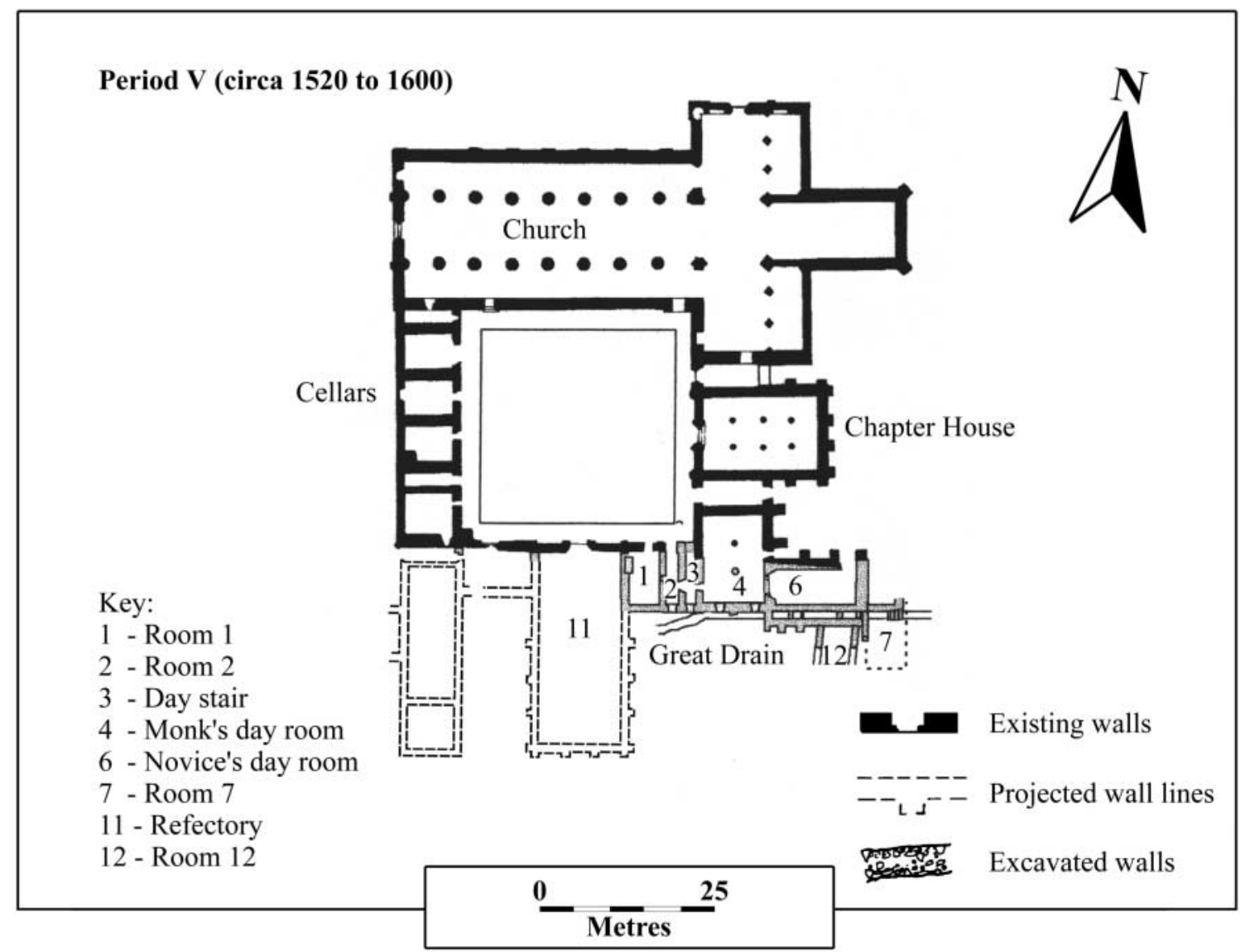

Illus 8 Period V

demolished structure. Unfortunately, little of the plan of the building from which structure 13 derives was recorded and its interpretation is therefore unresolved.

\subsubsection{Room 8 (illus 6, illus 9 \& illus 10)}

This chamber was interpreted as the warming house or calefactory on the evidence of a large fireplace (context 057) and hearth (context 043) located centrally in the west wall (context 004). The room measured $6.66 \mathrm{~m}$ north/south by $7.75 \mathrm{~m}$ east/west, internally, with likely access via a door (D2 on illus 9) lying towards the north-east corner, furthest from the fire itself, opening onto the cloister. The north side of the fireplace was plainly visible within the fabric of the 19th-century manse boundary wall (context 007). Only rough footings for the hearth were found and no trace of an original surface of fired stone flags or cobbles was revealed. The hearth kerb survived as a single row of pitched stones. The fireplace was $2.5 \mathrm{~m}$ wide and $600 \mathrm{~mm}$ deep, with the opening standing to a height of $2.9 \mathrm{~m}$. The fireplace and west wall (context 004) were later incorporated into room 9 (Period II, below), but the south wall (context 050) was largely removed during later works. This wall was confirmed as an original 12th- century feature by limited excavation over its assumed line exposing $2.2 \mathrm{~m}$ of its length. Only the lowest courses of the clay-bonded wall were revealed; these were $1.1 \mathrm{~m}$ wide, standing to a maximum surviving height of $260 \mathrm{~mm}$ (1-2 courses). The other walls of room 8 were comparable in size, being $1.06 \mathrm{~m}$ wide.

\subsubsection{Room 11 (illus $6 \boldsymbol{\&}$ illus 10)}

The probable site of the refectory, placed centrally in the south range and excavated by the Reverend Christie between 1911 and 1914, was only cursorily examined in the recent excavation. The interpretation of this Period I chamber as an early version of the refectory, extended in Period II, is inevitably conjectural due to the limited area actually excavated . There was sufficient evidence to show however that the Period 1 chamber was similar in plan to the contemporary room 8 and lay within the line of the early south range. The location of the refectory as discovered by the Rev. Christie is entirely typical of the Cistercian plan, where by projecting the enlarged room 11 southwards, access between the cloister and the buildings within the south range was maintained.

The west wall was comprehensively robbed, and 


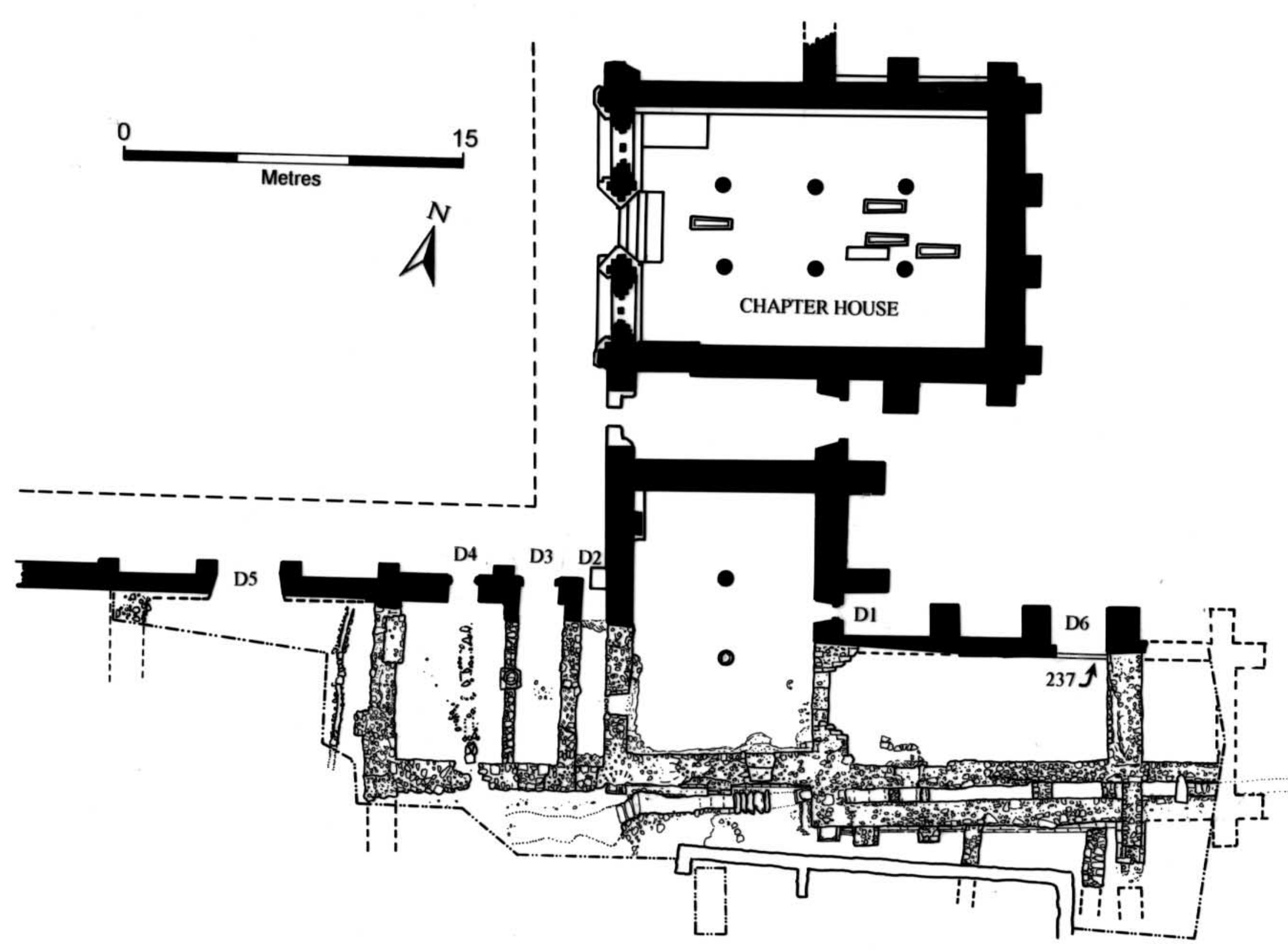

Illus 9 The excavation area, all periods, showing doorways mentioned in the text 


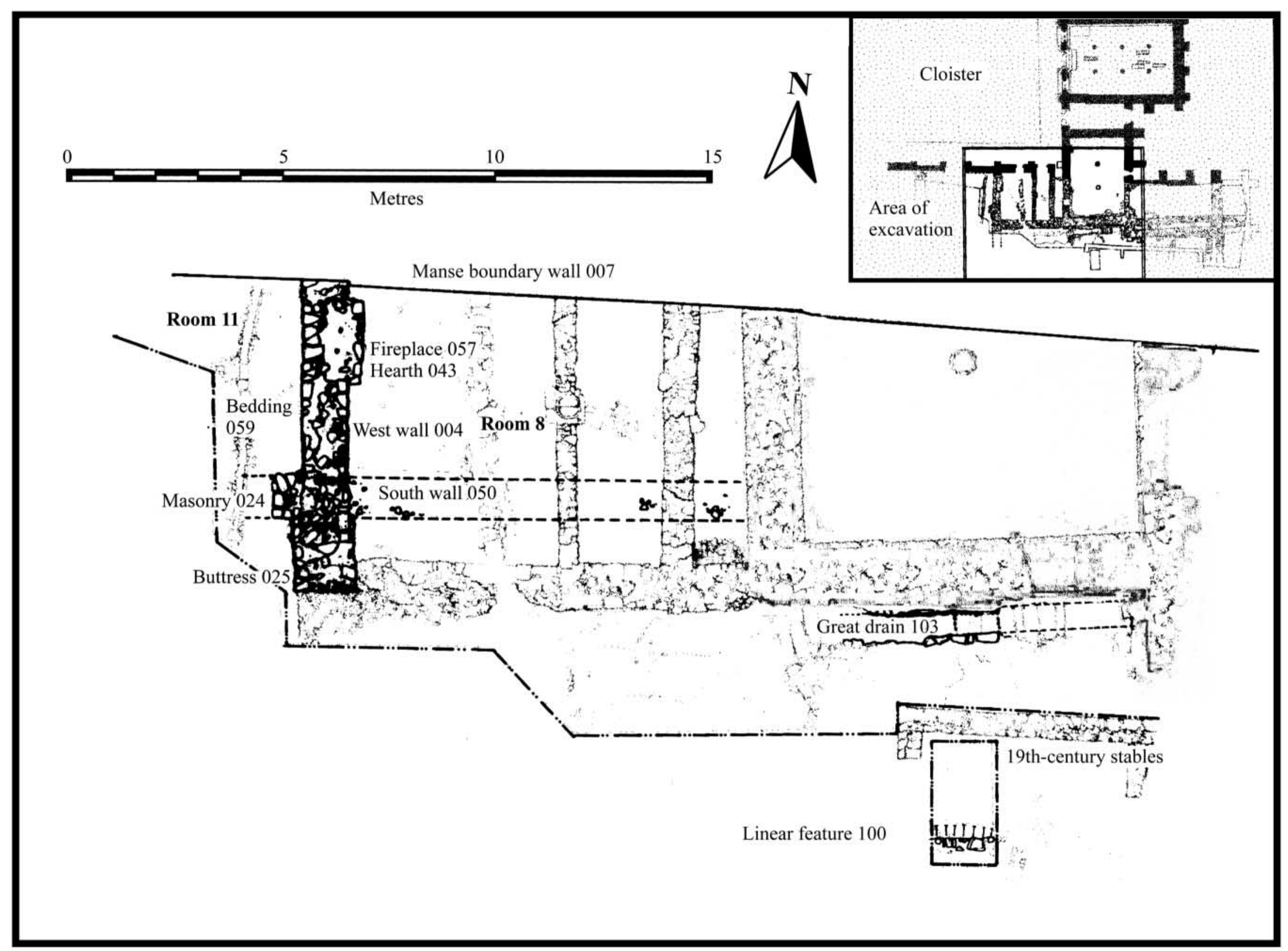




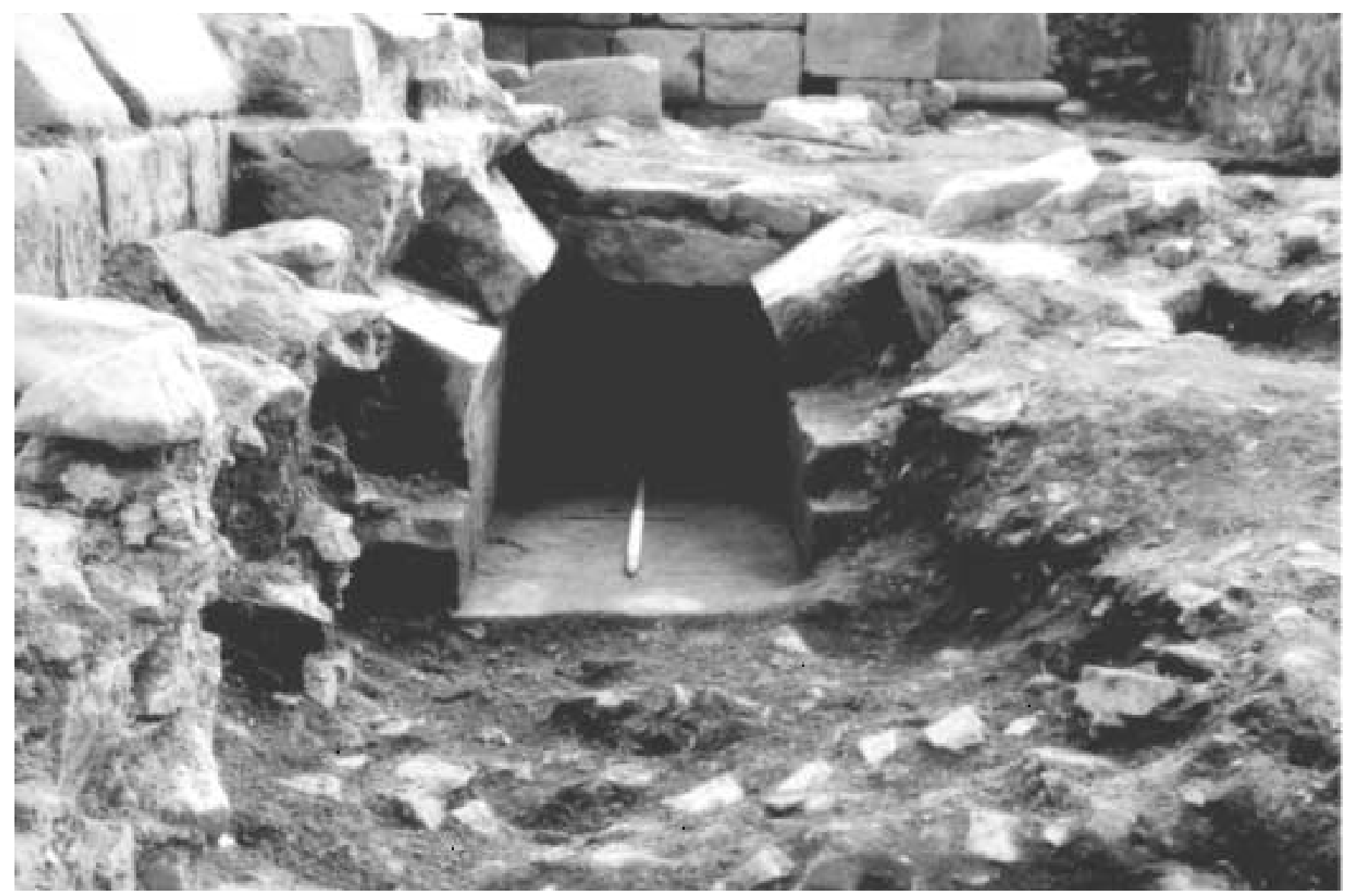

Illus 11 The great drain below a buttress (context 056), from east

survived as a short section of wall-core, with no facing stones in situ. A short section of masonry (context 024) which projected from the west wall of room 8 probably represented the surviving element of the Period I south wall of the refectory, prior to its extension southwards in Period II. The bedding for a flagged floor (context 059) survived within the excavated area of room 11, confirming the artificially terraced nature of the sub-floor deposits from its earliest construction.

\subsubsection{Great drain (illus 6 \& illus 10)}

A finely built stone drain (context 103) lay along the south side of the buildings of the south range. As laid out during the 12th century (in Period I) it followed a straight west/east route some $2 \mathrm{~m}$ south of rooms 8 and 11. The channel was well-constructed, with a flagged floor and cut ashlar sides, but without capstones. The absence of capstones in this period is implied by the clearly secondary work during Period II, where caps were introduced over the re-routed drain channel west of the latrine block. Only $5 \mathrm{~m}$ of the original line of the drain channel survived west of room 5 , but combined with its route below the first floor latrine block in Period II, a total of span of $30 \mathrm{~m}$ was cleared by excavation, exposing a drain with a width of $500 \mathrm{~mm}$

\subsection{Period II: $c$ 1230-1320}

The Period I arrangement of the abbey buildings was probably a staged development culminating, within the excavated area, with the room $4 / 5$ complex. The layout of the buildings that evolved from this saw further development of two of the main claustral structures - the chapter house and refectory - as the wealth and prestige of the house developed in the 13th century. The evidence for the enlargement of the refectory, and its realignment on a north/south axis, is to a large extent derived from the excavations of the earlier 20th century, conducted by Reverend Christie (1914). In this period too room 8 was enlarged to form room 9 . It is likely that rooms 4 and 5 were also part of the wholesale upgrading of the house from the mid 13th century, replacing earlier, simpler facilities. Within the cloister this period was most spectacularly demonstrated by the work on the chapter house, with the addition of a splendid new door and window in its west wall. All this work is seen as part of a progressive development of the embryonic layout of Period I during the 13th century, culminating in the fully formed Period II plan. The apparent prosperity of the house, with an increasingly complex organisation, is also implied by some of the faunal evidence from the site. In addition to the structural remains, Period II contexts provided evidence of fish remains (see 13. Fish and crustaceans), indicating access to deep sea fisheries and fishponds. 


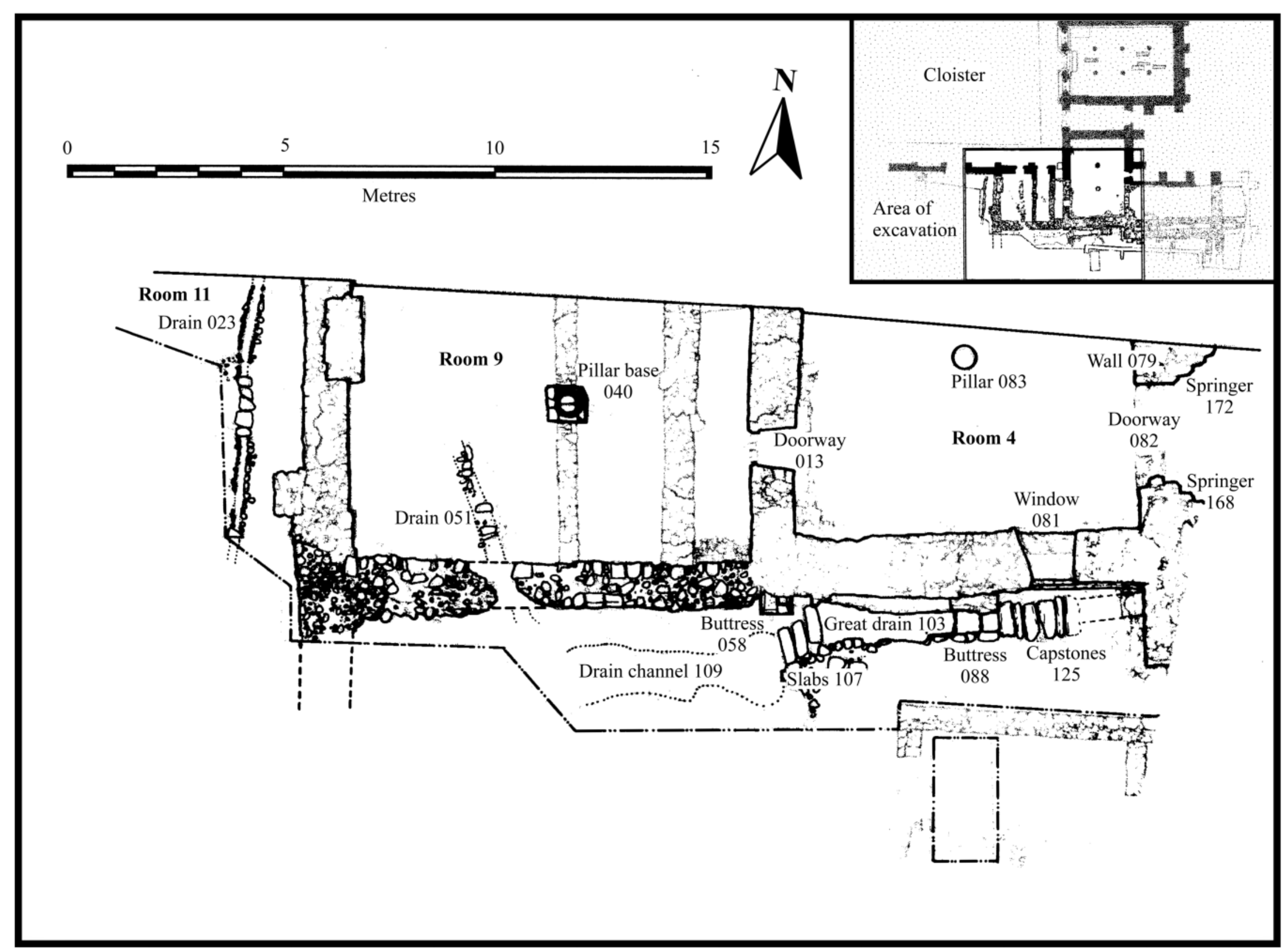




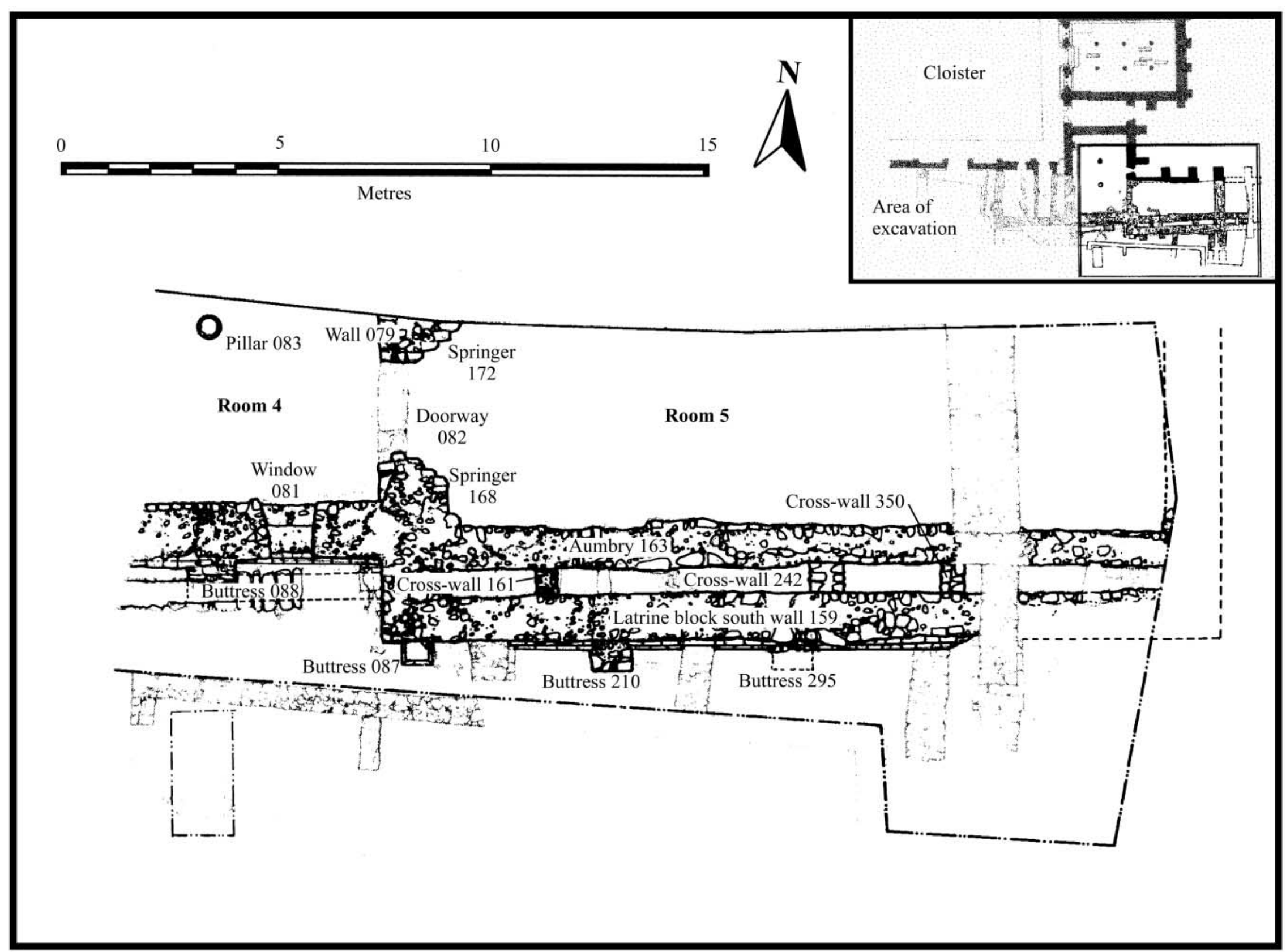




\subsubsection{Room 11 (illus 6 \& illus 12)}

It is likely that a system of sub-floor drains in rooms 11, 9 and 5 were laid at this time, as they appear to carry rainwater from the completed claustral ranges and were cut through the Period I south wall in room 11 (context 024 on illus 10 ). In room 11 the drain comprised a crude gully (context 023) capped with dry stonework and presumably obscured by the now robbed floor. The drain ran north/south on the east side of the refectory, and probably emptied directly into the great drain on its new route, which traversed the room west/east. The drain, which was comparable to that found in room 9 (context 051) extended over a distance of $c 12 \mathrm{~m}$ between the south cloister alley and the Period II great drain.

\subsubsection{Room 4 (illus 6 \& illus 12)}

Room 4 is identified as the monks' day room. Before the programme of excavations, the manse garden wall (context 007 on illus 10; illus 4) traversed room 4; the remains of the northern half of the chamber, including one of its pillar bases, were already exposed.

Access from the warming house (room 9) to room 4 was via a doorway (context 013), slightly splayed in plan, and widening inwards towards the latter room (from $800 \mathrm{~mm}$ to $1.12 \mathrm{~m}$ in width). Distinctive diagonal tooling was recorded on the margins of the door, with evidence of the iron bolt-holes still clear in the south side.

Two octagonal pillar bases provided additional support for the six-bayed vaulted roof. Only one pillar was excavated (context 083), standing on the central north/south axis of the room at a point $4.9 \mathrm{~m}$ north of the south wall. The pillar itself comprised two elements: a circular pad, $700 \mathrm{~mm}$ in diameter and $90 \mathrm{~mm}$ high, formed the base for the single surviving basal column stone; this in turn was octagonal in plan, measuring $510 \mathrm{~mm}$ wide and $320 \mathrm{~mm}$ high. In addition to doorway 013, the only other point of access to room 4 was via a door (D1 on illus 9) leading directly out of the claustral buildings on the east side.

A single window embrasure (context 081; see also illus 17) survived in the south wall, possibly one of a pair, the western equivalent having been removed in the general robbing of that part of the wall. As excavated, window 081 had clearly been modified and ultimately blocked, but as laid out originally it formed a splayed opening, expanding inwards, varying from $1.03 \mathrm{~m}$ to $1.39 \mathrm{~m}$ in width. The primary work for the window could be distinguished from later blocking, being of superior construction, and featuring the same well-tooled sandstone details noted in door 013 . The likely double-windowed plan for the south wall of room 4 was also implied by the position of buttress 088 (see also illus 17) which was located centrally along the south face of wall 080 . The windows were likely to have been symmetrically placed on either side of the buttress. The buttress was similar in scale and size to a further buttress outside room 5 (context 210 on illus 13), being $1.12 \mathrm{~m}$ wide and projecting southwards over the open great drain, spanning it with a finely constructed arch.

\subsubsection{Room 5 (illus 6 \& illus 13)}

Room 5 is identified as the novices' day room. The room was rectangular on plan, with an area of $17.4 \mathrm{~m}$ by $4.76 \mathrm{~m}$ internally. The walls stood to a maximum height of $2.6 \mathrm{~m}$, and were all of rubble build, bonded with a loose, sandy mortar, with sandstone mouldings for doorways and windows. In general, apart from the ribbed ceiling vault, the masonry was of rather rough character, suggesting that it had probably been rendered internally (see 10. Mortar and plaster). This was in contrast to the external faces of the walls of room 5, particularly on the south side, where the masonry was of generally better quality.

The ceiling comprised four rib-vaulted bays, springing from the corners of the room and wall faces. The majority of the rib vault fragments found during the excavation came from this room (see 9. Architectural fragments). Only two of the finelycarved springers located at the north-west and south-west interior corners of the room remained in situ (contexts 172 and 168 against west wall 079; see also illus 14).

Two window embrasures were evident in the north wall, with a doorway (D6 on illus 9) lying $2 \mathrm{~m}$ further east. The windows were at least $1.2 \mathrm{~m}$ wide, with the door being $1.9 \mathrm{~m}$ wide internally. All three of these features were later blocked. A further feature, surviving from the primary build of room 5 , was a recess or aumbry (context 163) lying towards the west end of the room, within the thickness of the south wall. The recess later suffered structural collapse, and was subsequently reduced in size and blocked (Period III, below). Originally it comprised a wellformed, wide-arched niche, standing above floor level to a maximum height of $1.47 \mathrm{~m}$, and being $1.2 \mathrm{~m}$ wide. It was built into the fabric of the south wall (context 169). There were indications that the recess had featured a door or shutter, in the form of a bolthole surviving in its west side. The modifications enacted on room 5 during Period III (below) obscured the general plan of the Period II building, but it is likely that the north windows and doorway were complemented in the earlier phase by a further window at the east end of the chamber. Thus, there would have been a symmetrical series of embrasures which were generously proportioned internally, offering good light within the room.

Only two of the Period II south buttresses were revealed in plan (contexts 087 and 210) and both would be replaced by larger structures during Period III (contexts 170 and 173, illus 17). The scar of a third buttress could also be seen in the south elevation (context 295 on illus 17) and probably belongs to Period II. These buttresses were relatively light, 
Springer 168

East facing

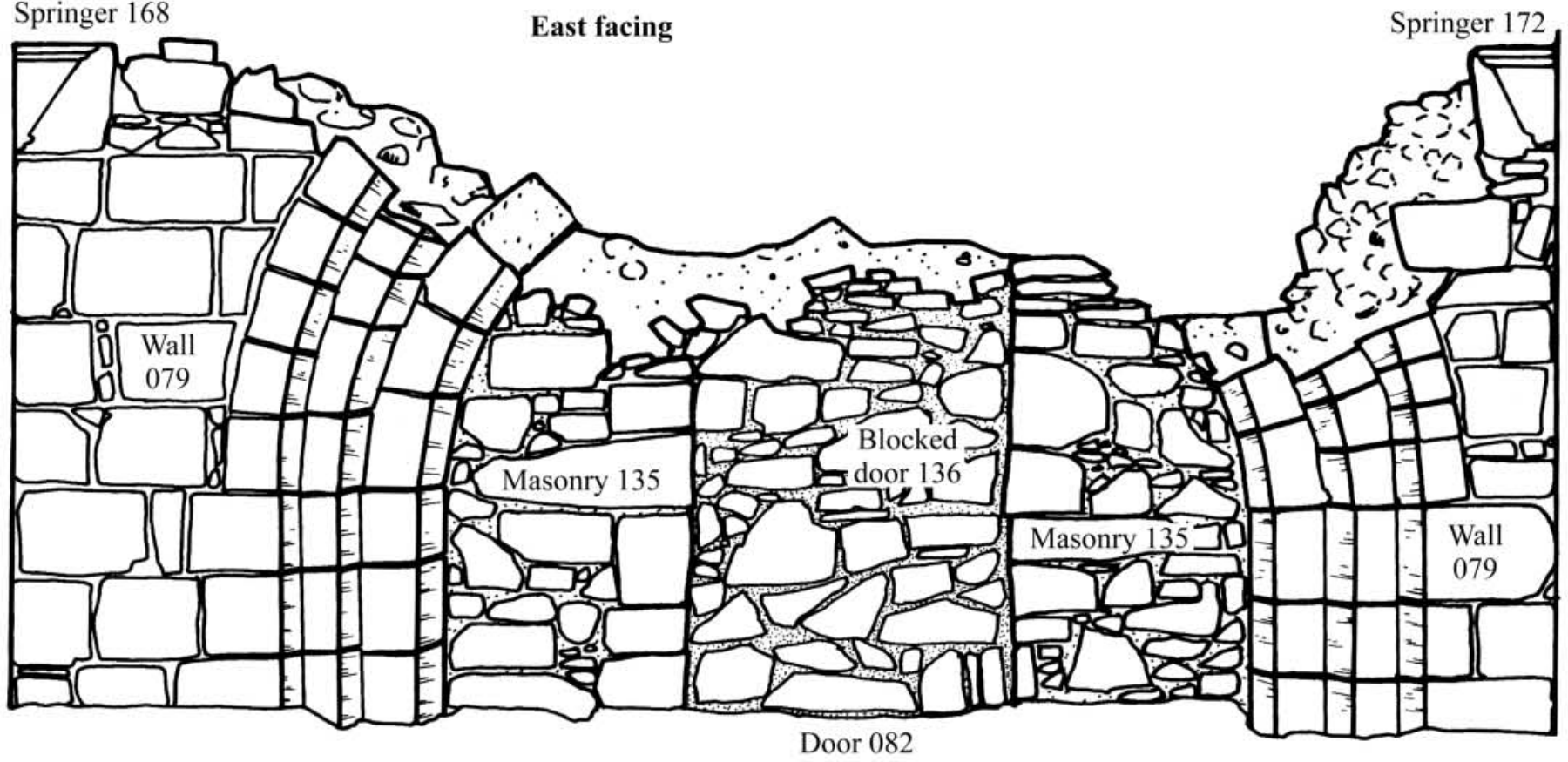

0

Metres

West facing

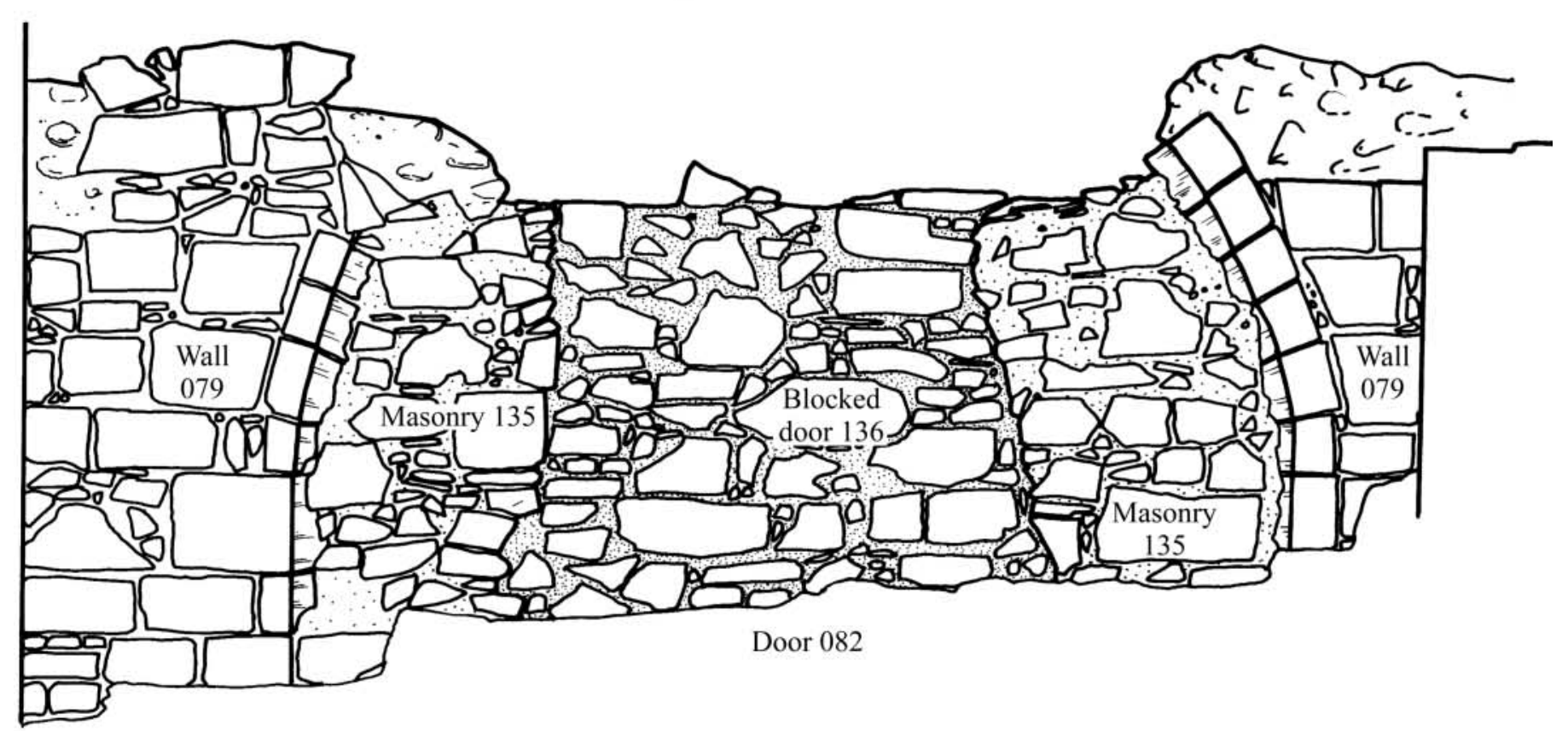

Period II - Contexts 079, 082, 168, 172 Period IV - Context 135

Period V - Context 136

Illus 14 Elevations of the west door, room 5/6 
extending only $0.75 \mathrm{~m}$ from the base of the south wall, a factor which may have contributed to the destabilising of room 5, prompting subsequent Period III repairs.

\subsubsection{Room 9 (room 8 enlarged) (illus $6 \&$ illus 12)}

The original warming house (Period I, room 8) was extended southwards by a distance of $2.45 \mathrm{~m}$ internally, creating a new chamber measuring $9.83 \mathrm{~m}$ east/west by $6.66 \mathrm{~m}$ north/south (now room 9 ). This extension was achieved by raising the floor of the room by dumping clay-rich material over the remains of the Period I south wall (context 050). This material (context 175) contained 13th-century pottery (see 6. Ceramics), and served as levelling for the footings of the new south wall (context 005). The Period II masonry was generally of more massive build, with walls thickened to $1.63 \mathrm{~m}$ as compared to $1.06 \mathrm{~m}$ in Period I. The Period I buttress (context 025) was absorbed at the north end of the new extended west wall of room 9 . It was also clear that the footings for the Period II masonry were of more careful construction, comprising wide, shallow, sequential rafts over which the standing masonry was raised.

The Period II roof was a quadripartite vaulted structure supported on one central pillar base (context 040). The pillar was octagonal in plan, measuring a maximum of $620 \mathrm{~m} \times 560 \mathrm{~mm}$, and stood to a height of $350 \mathrm{~mm}$ above its basal plinth. The plinth itself was a rough square construction of mortared stone measuring $1 \mathrm{~m} \times 1 \mathrm{~m}$. Traces of a stone-lined and capped drainage channel (context 051), later rerouted in Period IV, were found towards the west end of room 9, exploiting the newly re-routed great drain now lying approximately $1.5 \mathrm{~m}$ to the south.

\subsubsection{Great drain modified (illus 6, illus 12 \& illus 13)}

The large stone drain (context 103) running by the outer face of the buildings of the south range has been present in Period I but would now be adapted. A latrine block projected over the drain at first floor level, above room 5 . The latrine block was supported over the drain by the south wall of room 5 and by an outer, buttressed wall (contexts 169 and 159 on illus 13). These walls effectively enclosed the drain, below, to form a continuous latrine slot, standing 2.8 $\mathrm{m}$ high above the floor of the channel. This deep slot was braced by three internal cross-walls (contexts 161,242 and 350), each of which was of slightly different build. The westernmost cross-wall was also the most elaborate, with a finely constructed arch at its base, spanning the channel. The middle wall lay $5.2 \mathrm{~m}$ to the east and featured an angled base over the channel, dropping north to south. The easternmost wall had simply a straight-bottomed span.
Each of these features incorporated the channel, varying from $1.2 \mathrm{~m}$ to $0.75 \mathrm{~m}$ in width. The variation in their build may betray the dual function of these cross-walls, in that they partitioned the drain as well as supporting it, creating at least four separate sectors within this part of the channel. It is possible that the first sector was a secluded latrine, with more communal use being reflected by the rather cruder works of the other three compartments. It may also be the case, however, that the first or westernmost sector was not a latrine but simply a drain, with latrine stalls being located instead at the extreme east end of the latrine block at first floor level, perhaps only exploiting the last $5 \mathrm{~m}$ or so of the channel.

The drain itself was gently inclined to assist the westward flow of effluent. Ultimately, it exited room 5 via an arched opening issuing into an uncapped, shallow, stone-lined channel. It is likely that it then proceeded across the open area beyond the claustral buildings and directly on towards Abbey Burn, some $100 \mathrm{~m}$ distant.

With the remodelling of rooms 11 and 9 the great drain was re-routed in order to avoid the destabilising of the new south wall of room 9. The buttress (context 058 on illus 12) at the external south-west corner of room 4 necessitated a sharp turn to the south-west for the drain channel, evinced by a few surviving floor-slabs (context 107) at this point. The route further west was indicated by a wide and rather irregular-sided channel (context 109), all former stonework (floors and sides) having been removed. This channel indicated that the finished drain may have been slightly wider than its Period I predecessor, being up to $750 \mathrm{~mm}$ wide compared with $500 \mathrm{~mm}$ wide in the earlier period. The new route followed a course $1 \mathrm{~m}$ south of the newly built south wall of room 9, and was characterised by the use of cruder rectangular stonework in its build. The stones at the base of the drain (context 107), and the caps (context 125) were supported on the south side of the drain by a raised terrace of dumped clay and stones. The need to cap the drain along its west line was probably a response to the use of this drain by the newly extended west ranges, for lay brothers' accommodation and waste disposal. This would necessitate the sealing of the channel before it entered the latrine block.

\subsection{Period III: $c$ 1320-1450}

This period reflects the repairs and conversions to room 5 arising from war damage and structural collapse combined. Room 5 was truncated and stabilised - creating the shorter room 6 - with the addition of room 12 against its south wall; room 9 was also subdivided. The resources of the community were clearly adequate for the necessary work, and growing trade links with mainland Europe are suggested by the increased incidence of imported pottery from Period III contexts (see 6. Ceramics). 


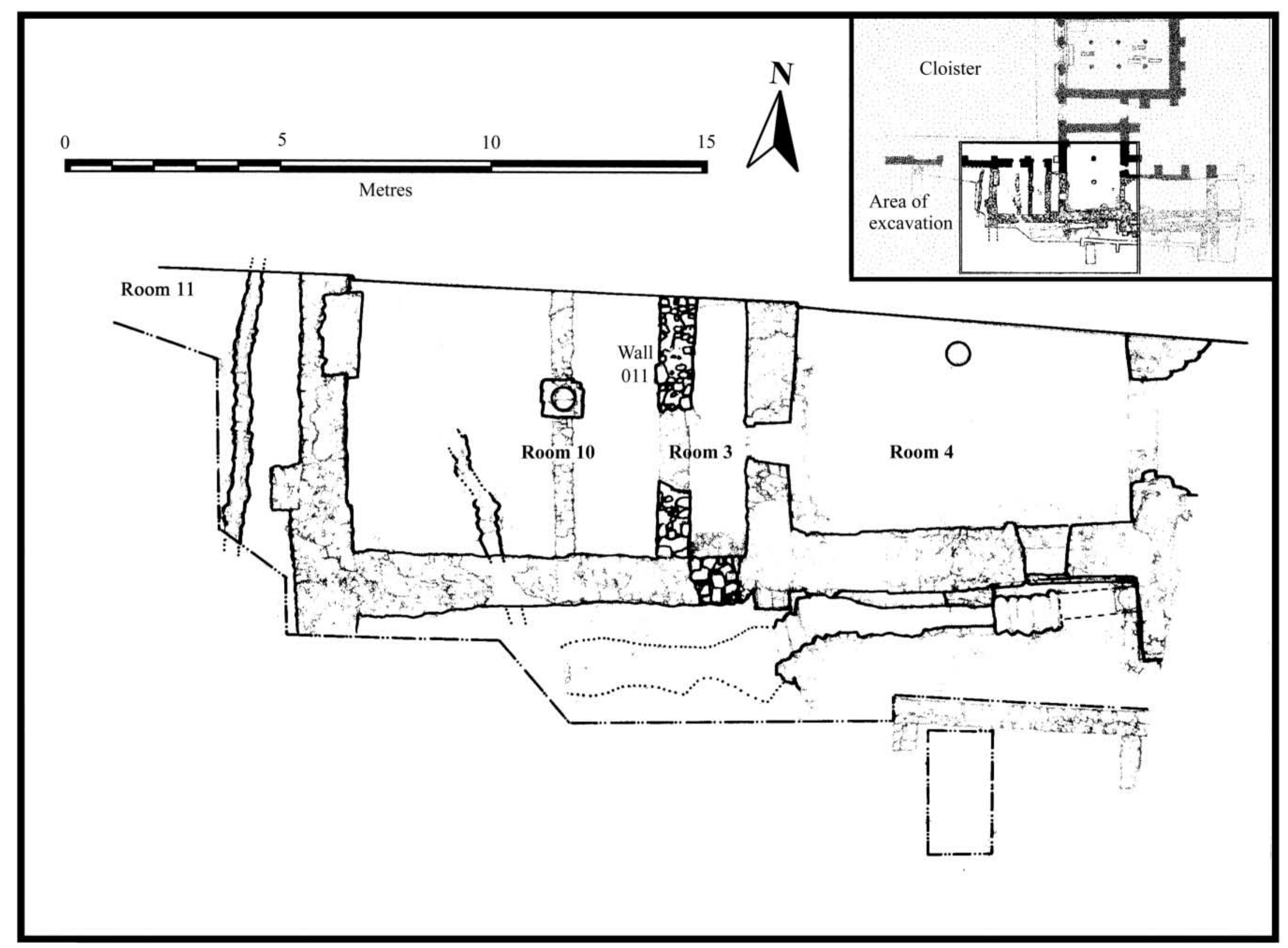

Illus 15 Period III features, west 


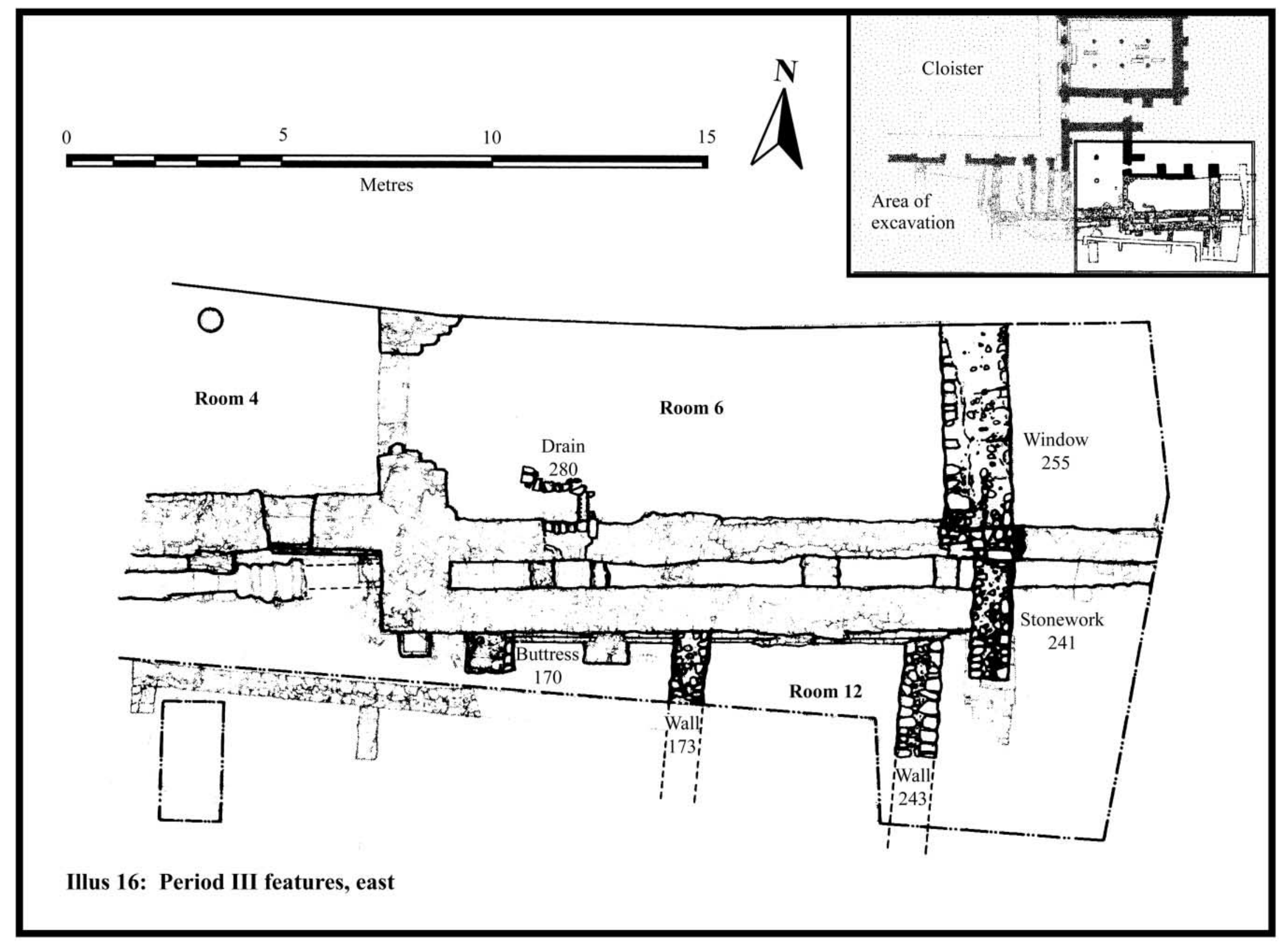

Illus 16 Period III features, east 

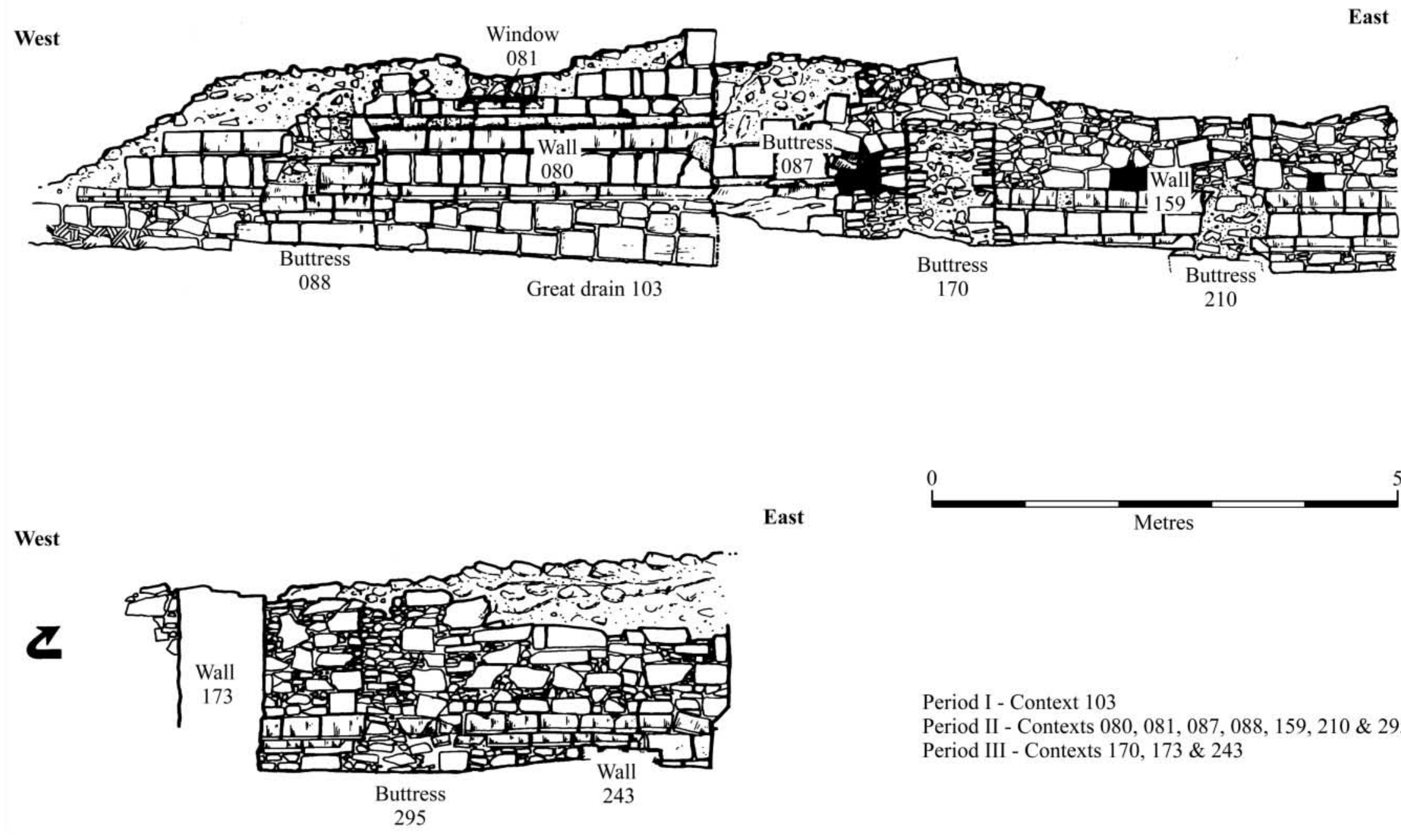

East

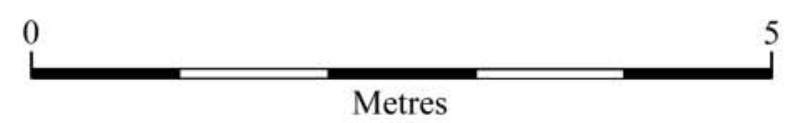

Period I - Context 103

Period II - Contexts 080, 081, 087, 088, 159, 210 \& 295

Period III - Contexts 170, 173 \& 243

Illus 17 Elevation of the south façade of the room 4 and room 5/6 complex 


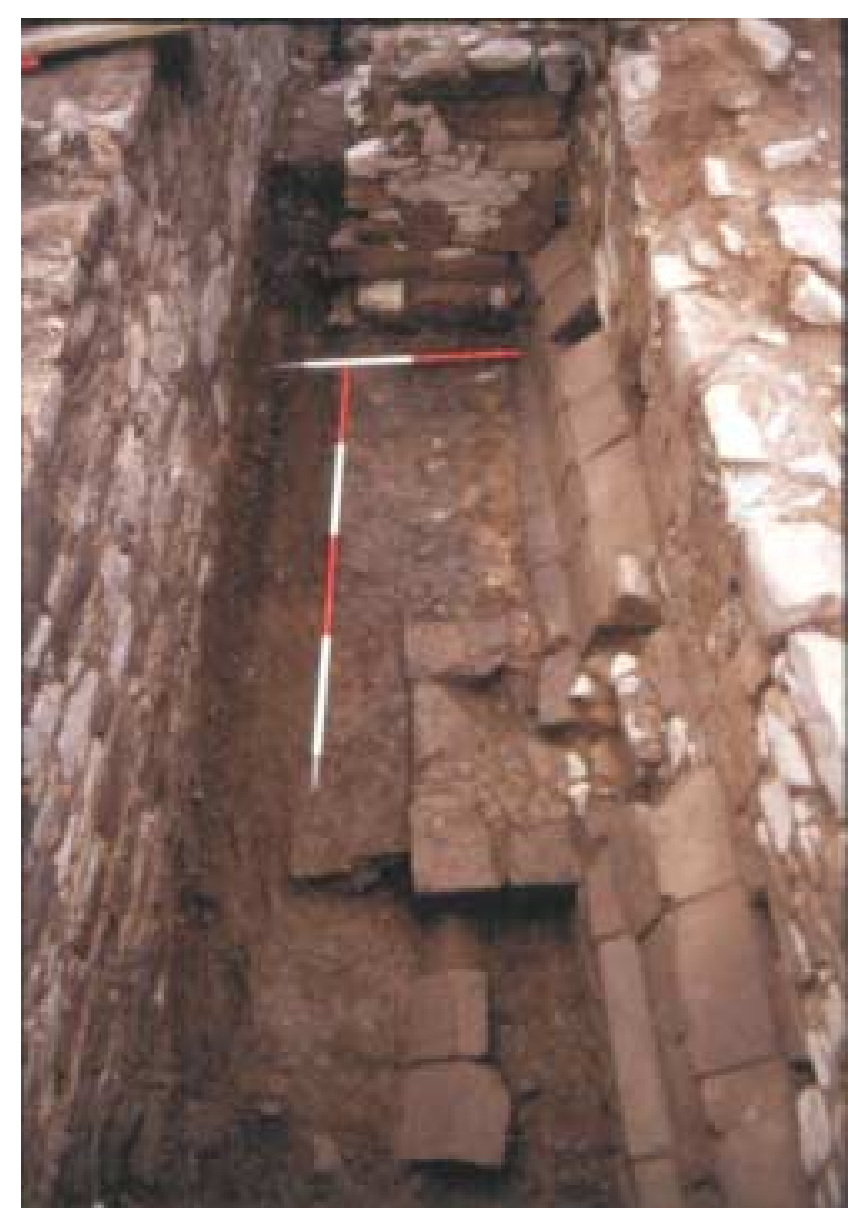

Illus 18 The south wall of room 5/6, showing Period II and III buttresses

\subsubsection{Rooms 10 and 3 (room 9 partitioned) (illus 7 \& illus 15)}

Two separate chambers were created by the subdivision of room 9 , with the construction of a cross-wall (context 011) lying towards the east end of this former (Period II) chamber. Room 10, which formed the Period III warming house, measured $6.6 \mathrm{~m}$ by 6.6 $\mathrm{m}$ internally and occupied the west part of the former room 9 , with room 3 being little more than a passage $1.3 \mathrm{~m}$ in width, to the east. Room 3 was accessed from the cloister via the Period I doorway into room 8, whereas room 10 saw the construction of a new north door (D2 and D3, respectively, on illus 9) towards the east end of the new room (and furthest from the fire, which remained in the west wall). A further door was provided between rooms 10 and 3 directly opposite the west door to room 4 . The new door, later blocked by Period IV masonry (context 034, below), maintained a through-route from the warming house to rooms 4 and 6 beyond. It is likely that the day stair, providing access to the dormitories at first floor level, was now located within room 3 , establishing a route from dormitory to cloister, without having to enter the new warming house.

The Period III cross-wall (context 011) was of significantly lighter construction that the other walls of rooms 10 and 3, being only $600 \mathrm{~mm}$ wide on average. The wall bore traces of plaster rendering over its rather crude rubble fabric on both its east and west faces, suggesting that rooms 10 and 3 were finished internally in this fashion. A small void was also introduced below the cross-wall; this seems to have acted as a flue or weeper for the cross-wall, although its precise function is not clear.

A new window (context 130) was opened to light room 3, occupying the full width of its south wall. Only the sill survived, the jambs and lintel having been completely robbed after the abandonment of the house.

\subsubsection{Room 6 (room 5 truncated) and the great drain (illus $7 \&$ illus 16)}

The most dramatic modification of Period II occurred with the truncation of room 5 to form room 6 . This was achieved by the demolition and wholesale robbing of the earlier east gable and the establishment of a new east wall $3.3 \mathrm{~m}$ further west (context 234 on illus 16; see also illus 19). This exercise saw the removal of one of the vaulted bays in the Period II room 5 , and a consequent truncation of the latrine block space at first floor level, reducing the undercroft to a three-bay layout. This created a room measuring $12.38 \mathrm{~m}$ by $4.76 \mathrm{~m}$ internally. There was no other major change aside from the blocking of the Period II south wall aumbry with crude masonry, which was in turn rendered over. A simple drain (context 280) was introduced, following an irregular route across the floor and emptying into the great drain below the blocking of the aumbry. The new east wall featured a large central window (context 255 on illus 16; see also illus 19), no doubt a direct successor to an equivalent window in the Period I east wall. Externally, however, there was some evidence for the reasons behind the drastic Period III rebuilding of room 5, in that the Period II buttresses were replaced by two distinct measures for the consolidation of the south wall of the latrine block (with room 6 below). A massive buttress (context 170) was raised against the south face of the wall, towards its west end; and cross-wall 241 (illus 19 \& illus 24) was augmented to form a similar buttress at the now extreme south-east corner of the remodelled latrine block. The south wall was further stabilised by the addition of room 12 (below), abutting its outer face. Within the latrine shaft above the drain, already compartmentalised, the walls were braced by the addition of crude blocks of stone simply jammed into place, particularly towards the west end of the shaft, in the vicinity of the blocked Period II aumbry. The progress of the drain beyond the now truncated latrine block was characterised by crude repairs over Period II side walls. These repairs were intended to reinforce the collapsing sides of the Period II drainage channel by the addition of unbonded rubble patching, maintaining the channel depth of $c 1 \mathrm{~m}$ before it emerged through the residual arched opening at its 


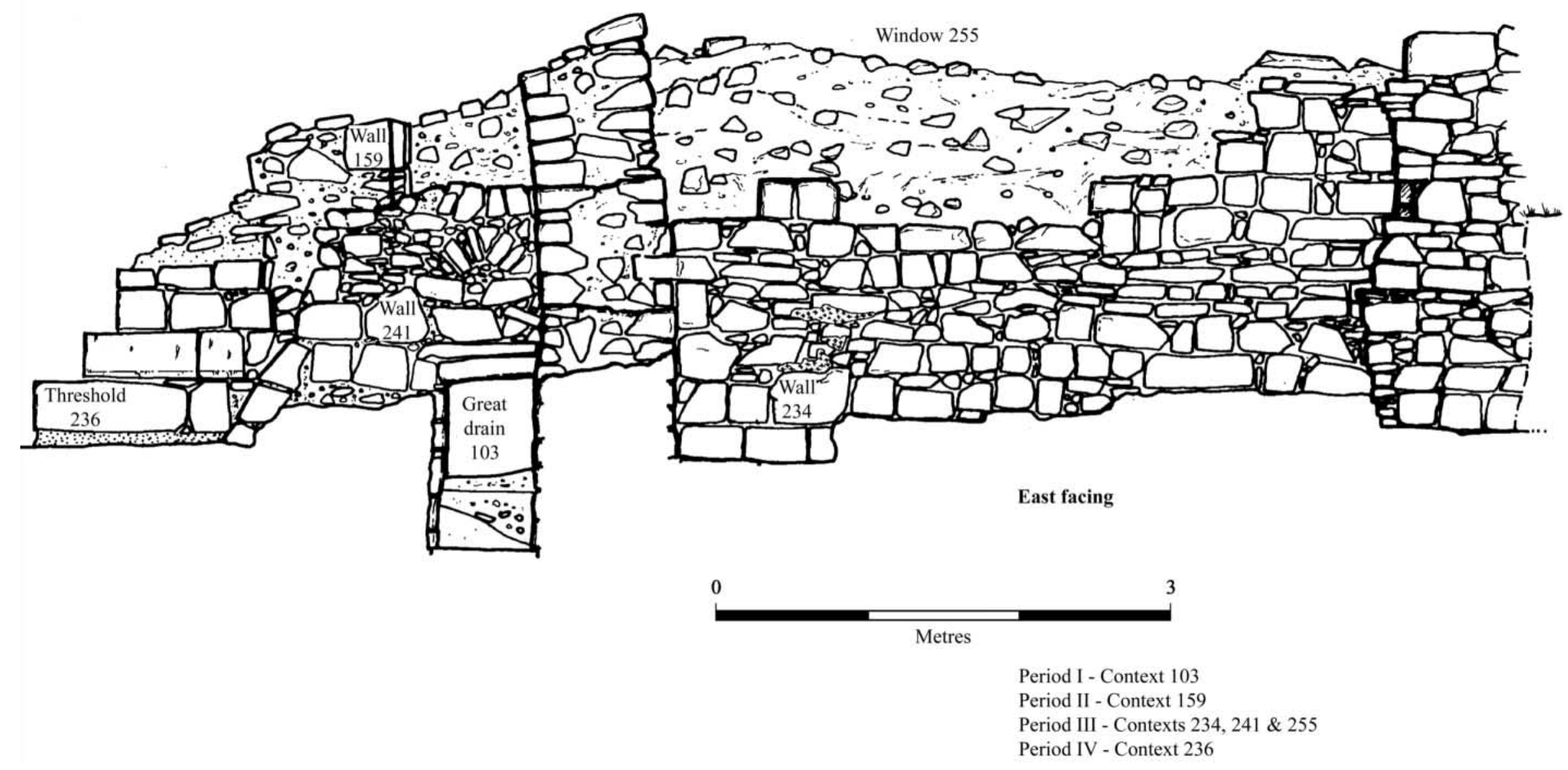

Illus 19 Elevation of the east-facing end-wall of Room 6 
east end. It is likely that the drain was not capped beyond the new latrine block east wall, capping only occurring when there was an attempt to create a crude building butted onto room 6 , namely room 7 (Period IV, below).

\subsubsection{Room 12 (illus $7 \&$ illus 16)}

This remains of this chamber was almost completely robbed and were also obscured by the building of the manse. The chamber was represented archaeologically by its west and east walls (contexts $173 \& 243$; see also illus 17), which were built against the outside face of room 6 and the latrine block. The walls were characterised by their crude build, and also by their distinctly oblique alignment when compared with the general plan of the Period II structures (they lay slightly north-east/south-west in alignment). The chamber was comprehensively damaged by the construction of the manse stable yard so that no internal floor deposits survived, nor was there any indication of access to the building. The surviving walls defined a structure less than $5 \mathrm{~m}$ wide, and it is possible that room 12 was intended to supplement the reduced space within the latrine block in some way.

\subsection{Period IV: c 1450-1520}

This period saw the addition of private accommodation, as well as service space, responding to the changing use of the house from its communal life to one of more individual pursuits. This was achieved by markedly cruder building works, identified by a tendency to recycle any redundant stones form other parts of the site, and the simplicity of the changes enacted on the south range of the cloister. The majority of faunal and environmental evidence also pertained to this phase of occupation and in broad terms confirmed a less formal, but far from impoverished regime. This is implied in the first instance by the very presence of dumped rubbish and drain-fill close by living quarters. Analysis of this material indicated that the community enjoyed a diverse diet, based primarily on agriculture and livestock husbandry, with some reliance in addition on local natural resources, such as freshwater fish, wild duck and berries (see 11. Plant remains, 12. Mammals and birds, and 13. Fish and crustaceans).

\subsubsection{Rooms 1 and 2 (room 10 subdivided) (illus 7 \& illus 20)}

Two small rooms were created by the subdivision of room 10 (ie further subdivision of Period II room 9), and by the blocking of the Period III door to room 3 from the warming house. This resulted in a plan comprising three separate chambers accessed only from the south cloister alley.

Room 1 was formed by a partition wall (context 003) within former room 10, incorporating the Period II pillar base (context 040), and creating a chamber measuring $4.76 \mathrm{~m}$ by $6.66 \mathrm{~m}$. At this time the Period II drainage channel (context 051) was recut to form a stone-lined channel (context 022) measuring $380 \mathrm{~mm}$ wide by $280 \mathrm{~mm}$ deep, running straight out towards the new cloister doorway (D4 on illus 9).

Room 2 covered a smaller area, measuring $1.9 \mathrm{~m}$ by $6.66 \mathrm{~m}$. This was augmented by a new south window (context 021), of which only the sill survived, the jambs and head having been entirely robbed. The new plan was completed by the closing of the Period III door between rooms 2 (formerly room 10) and 3 , all doorway details being now obscured by the claybonded masonry blocking (context 034).

\subsubsection{Room 7 and capping of the great drain (illus $7 \&$ illus 21)}

After the realignment of the east wall of the latrine block undercroft in Period III, the easternmost $4 \mathrm{~m}$ of the Period I great drain no longer featured as part of the latrine complex and was reduced to being a simple drainage channel. At this stage the capping of this section of the drain was introduced, partly laid over a spread of occupation deposits which lay to the south of the drain channel. Significantly, the capping for the drain was formed primarily by broken grave slabs, recycled from the adjacent monastic graveyard. One of these slabs, which was broken in two to form part of the drain capping, featured a finelycarved sword motif (illus 24). Evidently, high-status graves in the abbey were being robbed of their grave slabs as a convenient material for more basic uses elsewhere.

The need for capping, together with the remnants of a floor and threshold (context 236 on illus 19), are all probably best seen as evidence of a crude building (room 7) abutting the extreme south-east corner of the latrine block, possibly a timber lean-to structure. The presence of the threshold at least indicates that this was a roofed building and that access was from the west side, though the gap between this building and room 12 was very narrow, being only $1.1 \mathrm{~m}$ wide.

\subsubsection{Room 6 (illus 7 \& illus 21)}

The west arch in room 6 was reduced in size by the addition of masonry (context 135 on illus 14). The remaining opening measured $1.1 \mathrm{~m}$ in width, an appropriate size to receive a door. This appears to demonstrate how, for the first time, the open access between rooms 4 and 6 was removed, suggesting that separate functions were now served by these once closely-linked chambers. 


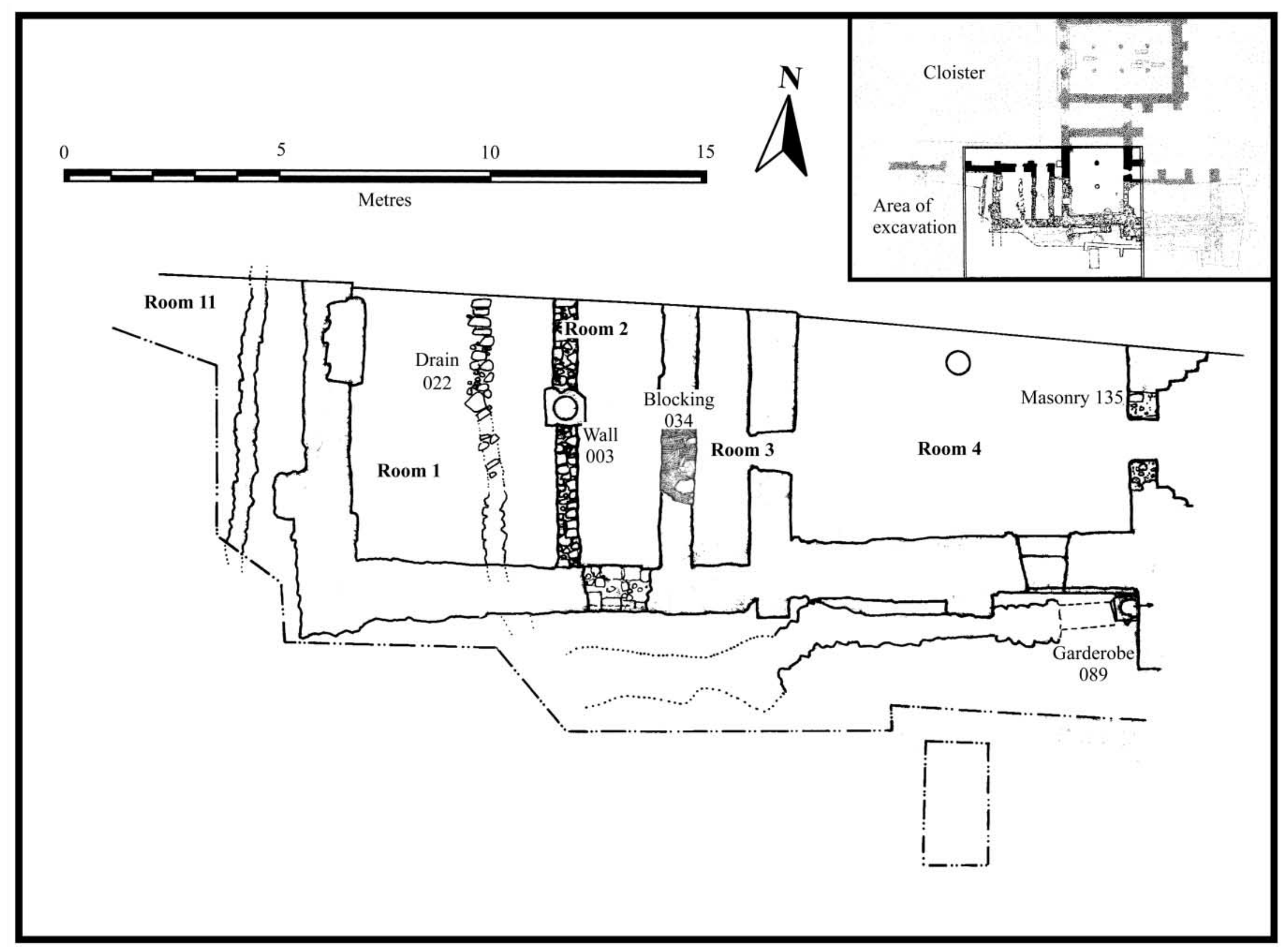

Illus 20 Period IV features, west 


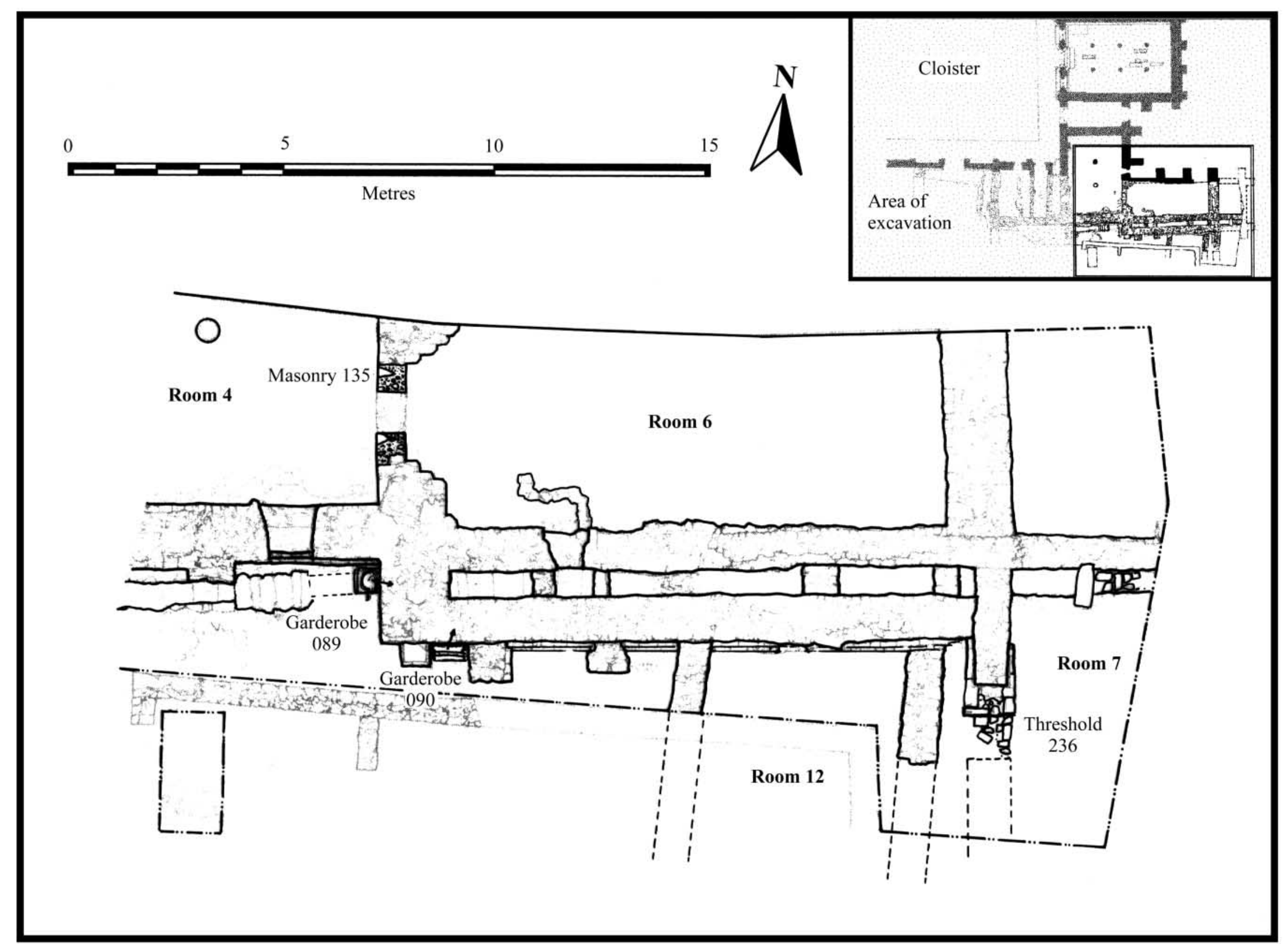




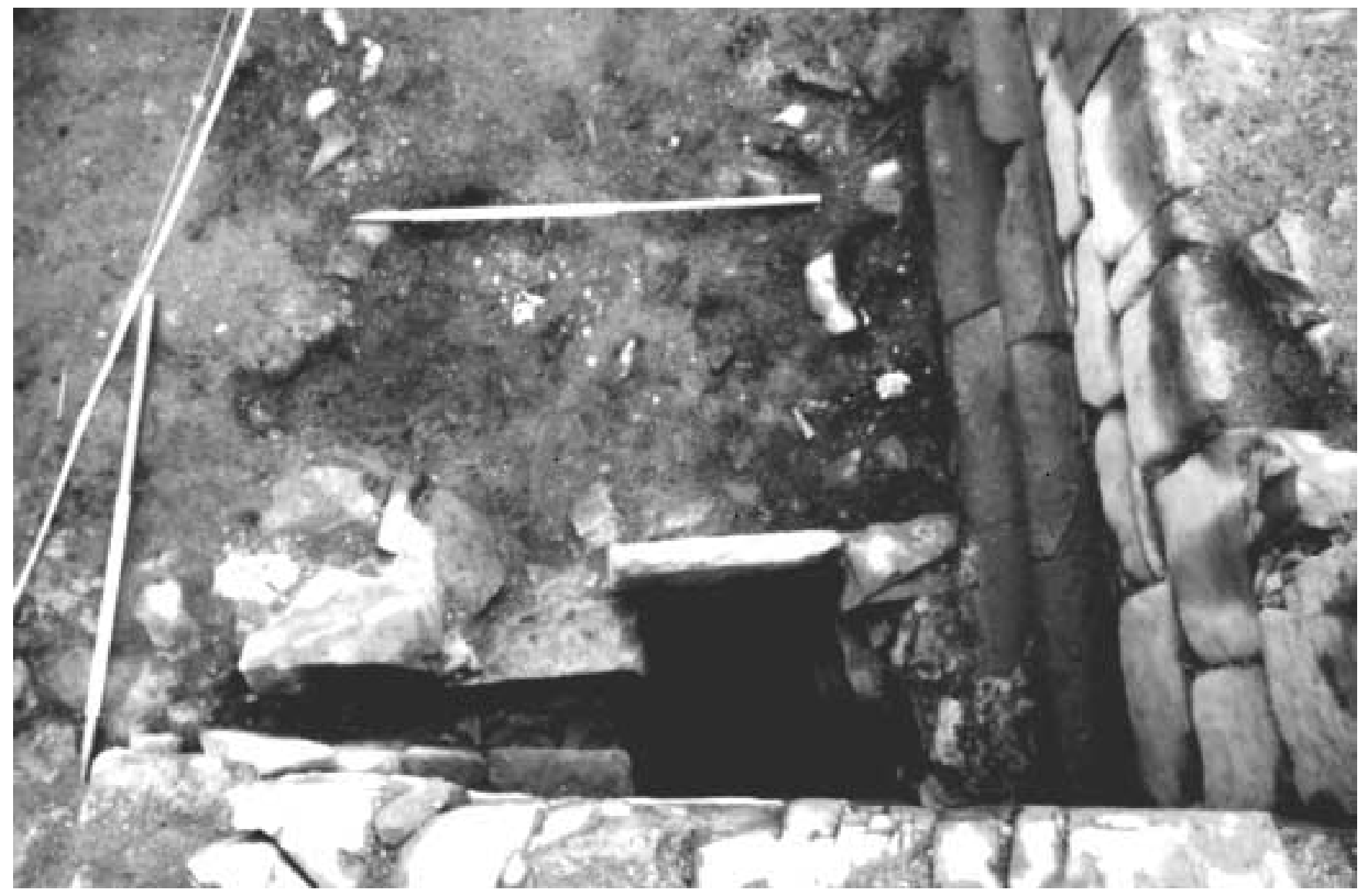

Illus 22 Period IV garderobe (context 089)

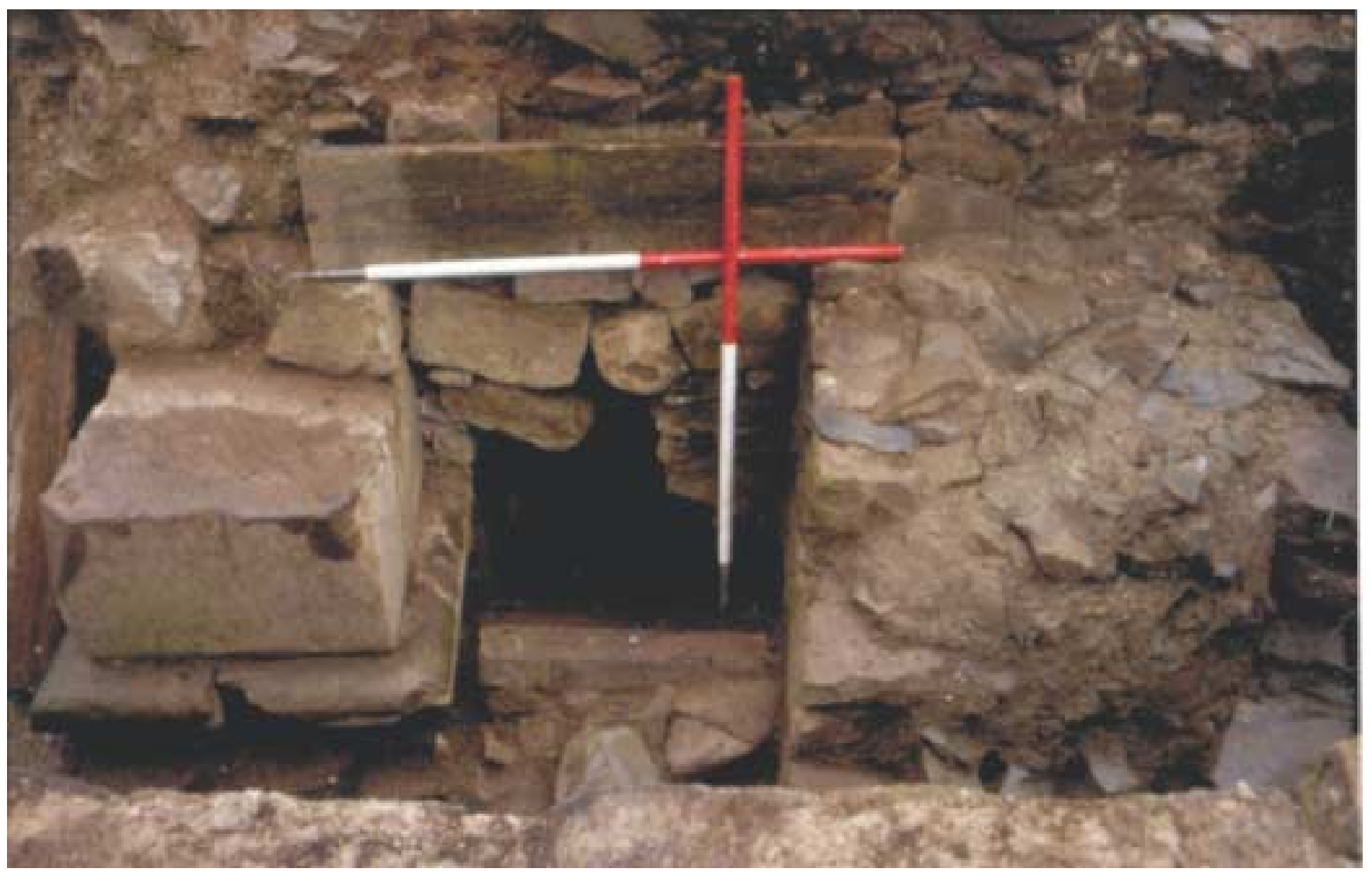




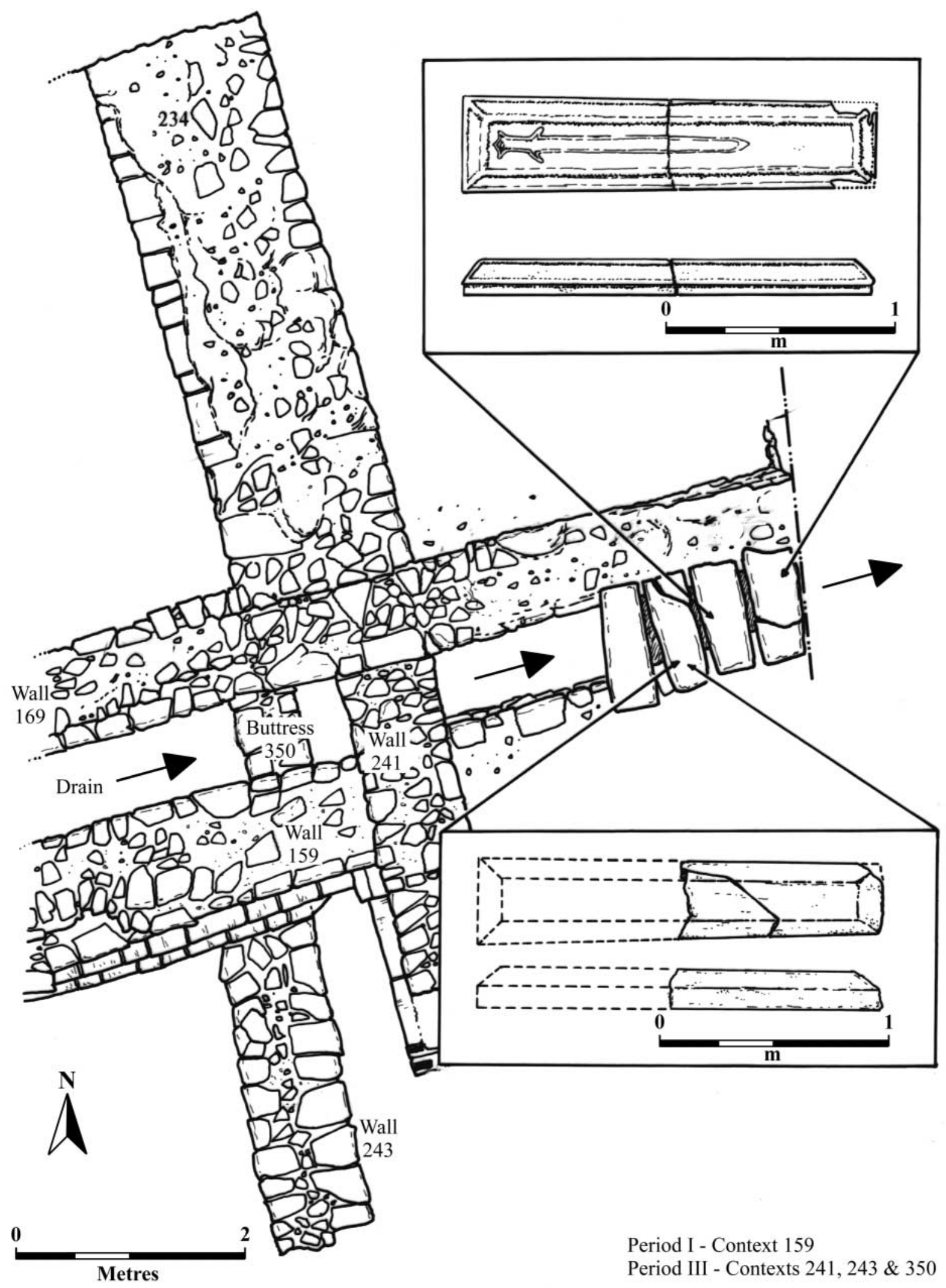

Illus 24 Re-used grave slabs over the great drain

\subsubsection{The great drain and garderobes (illus 7 \& illus 21)}

Period IV saw the abandonment of the latrines at first floor level in favour of two separate external garderobes with associated pits. Of the two garderobes, one (context 089) was located towards the external junction of the south wall of room 4 with the west wall of room 6 . The feature comprised a circular hole cut through a single block, over an angled 
base, emptying into the great drain from the west. Crude pitched slabs formed a simple drain into the pit from the south. The second garderobe pit (context 090) was located between two Period II buttresses 088. It comprised a single rectangular shaft over an angled base, emptying into the great drain from the south. Both garderobes were marked by the re-use of older masonry fragments in their construction, and both seem to have served the first floor chamber above room 6 . This implies that two discrete privies were in use, located towards the south-west corner of the upper chamber, the communal latrine stalls of Periods II-III now having been sealed over. It is also likely from this point onwards, up to the abandonment of the abbey, that the flow of water into the great drain at the extreme south-east corner of the site was not necessarily constant, if indeed any water now flowed through the channel at all. Water-borne silts were in evidence in the drain fill, along with material washed from the demolished structures above. Thus, the infill of the drain in the vicinity of the garderobes was probably periodically dug-out, rather than being flushed out by water in the drain. The last in situ garderobe fill was localised and quite distinct from the general mass of water-borne material both above and below it. Some of this type of material may well have formed part of the primary dumping over the nearby drain covers.

\subsection{Period V: c 1520-1600}

During the final period of occupation of the abbey buildings the features revealed by excavation appear to have become increasingly used as service space, perhaps even as cellars, in association with the use of the room 4 and 6 structures at first-floor level. The role of the abbey buildings at this time, under the auspices of an increasingly secularised management, may well have been reorganised to a more typical domestic, residential, albeit lordly, function as the numbers of the community dwindled away. It is equally clear, however, that sustained occupation throughout the 16th century was maintained at some level, and it is likely that the buildings forming the south-east corner of the cloister retained some use as post-monastic accommodation, perhaps even for the commendator himself during the middle decades of the 16 th century. Certainly a dynamic and wealthy household is suggested by the increased incidence of post medieval imported ceramics (see 6 . Ceramics), attesting that the produce of northern France was available to the later occupants of the site.

\subsubsection{Rooms 1 and 3 (illus 8 \& illus 25)}

In room 1 Period $V$ was marked by the addition of a low earthen bank (context 026), laid over the residual Period I hearth (context 043) and extending to run parallel with the south wall of the chamber. This feature stood only $150 \mathrm{~mm}$ in height and was probably designed to receive a sprung timber floor within a storage area, with the fireplace itself no longer in use.

Room 3 was augmented by the addition of two stretches of embanked material, one of which (context 032) effectively cut-off access to the cloister via door D2. This comprised a thick deposit of earthbonded masonry built directly between the long walls of the room. At the south end of room 3 a similar construction of clay and stones (context 020) was built against the north face of the south wall. In combination, these features served to reinforce the existing walls, rather than raise the floor, unlike the case of room 1.

\subsubsection{Rooms 4 and 6 (illus 8, illus 25 \& illus 26)}

A feature similar to that revealed in room 1 was laid along the south, east and west walls of room 4 . This deposit (context 064) comprised a low bank revetted with simple stonework along its east sector. Again it appears to represent the raising of the floor, perhaps to receive timber joists, after the primary floor surfaces had been removed. The Period II window was also likely to have been partially blocked at this time by the addition of crude claybonded stonework.

As part of this general blocking of doors and windows, it is likely that the reduced Period IV doorway (context 135 on illus 14) was sealed completely at this time by inserted masonry blocking (context 136), restricting access to room 6 to the Period II north door alone.

\subsection{Occupation over Periods IV and V}

A series of midden deposits and the fills of the great drain provided an unusually detailed insight into the occupation of the house over the late 15 th to late 16th centuries. Elsewhere, Period IV deposits from room 4 contained late 15 th-century ceramics (context 093) and Period V deposits in room 1 (contexts $231 \& 028$ ) contained material dating to the late 16th and early 17 th century. These deposits represent the last phases of occupation within these chambers, revealed at the upper limit of excavation.

\subsubsection{Middens (illus 27)}

An area immediately south of room 4 and north of the manse stable yard wall (context 071) was excavated in order to reveal any further surviving capstones over the great drain immediately before it entered 


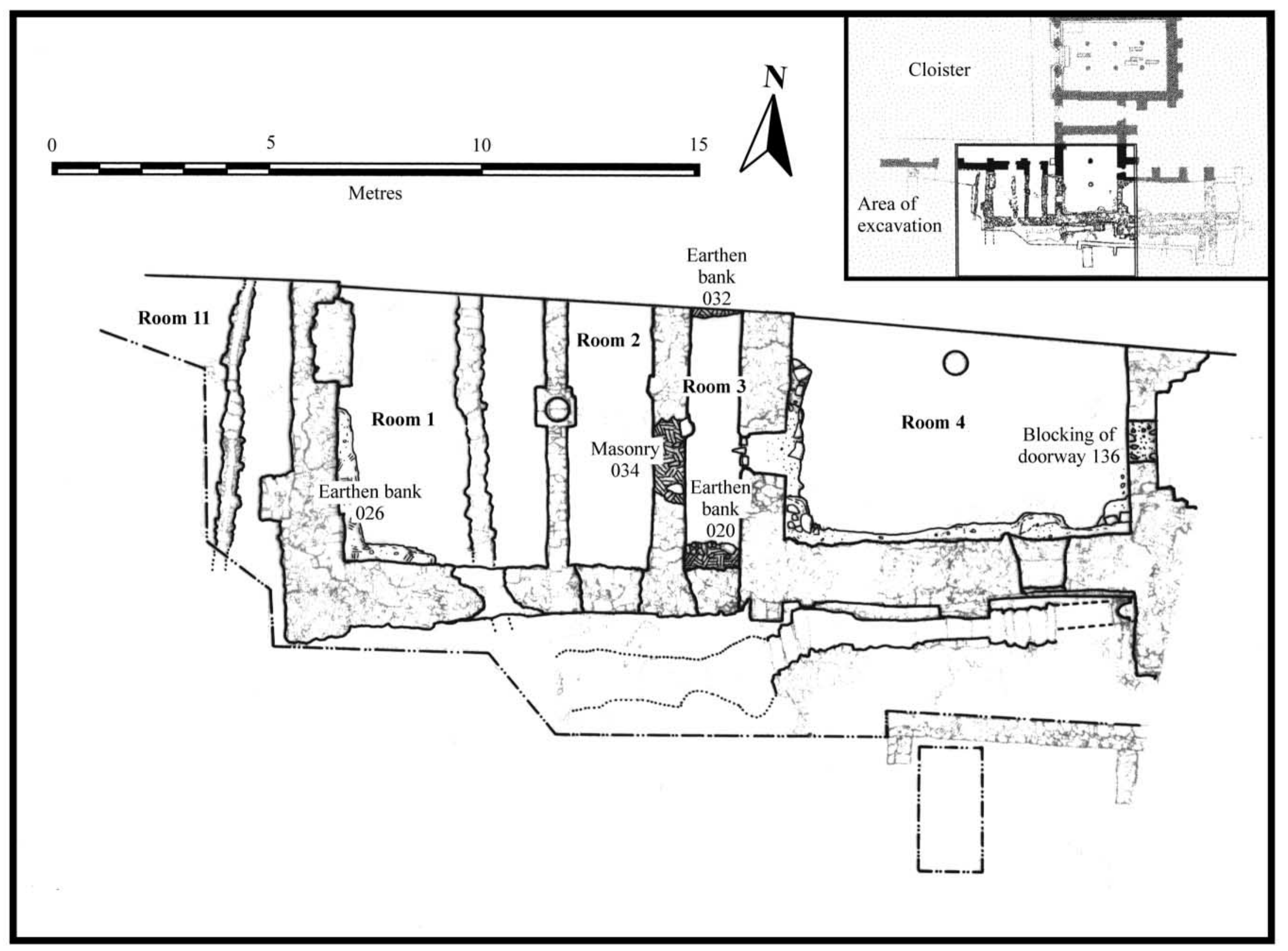




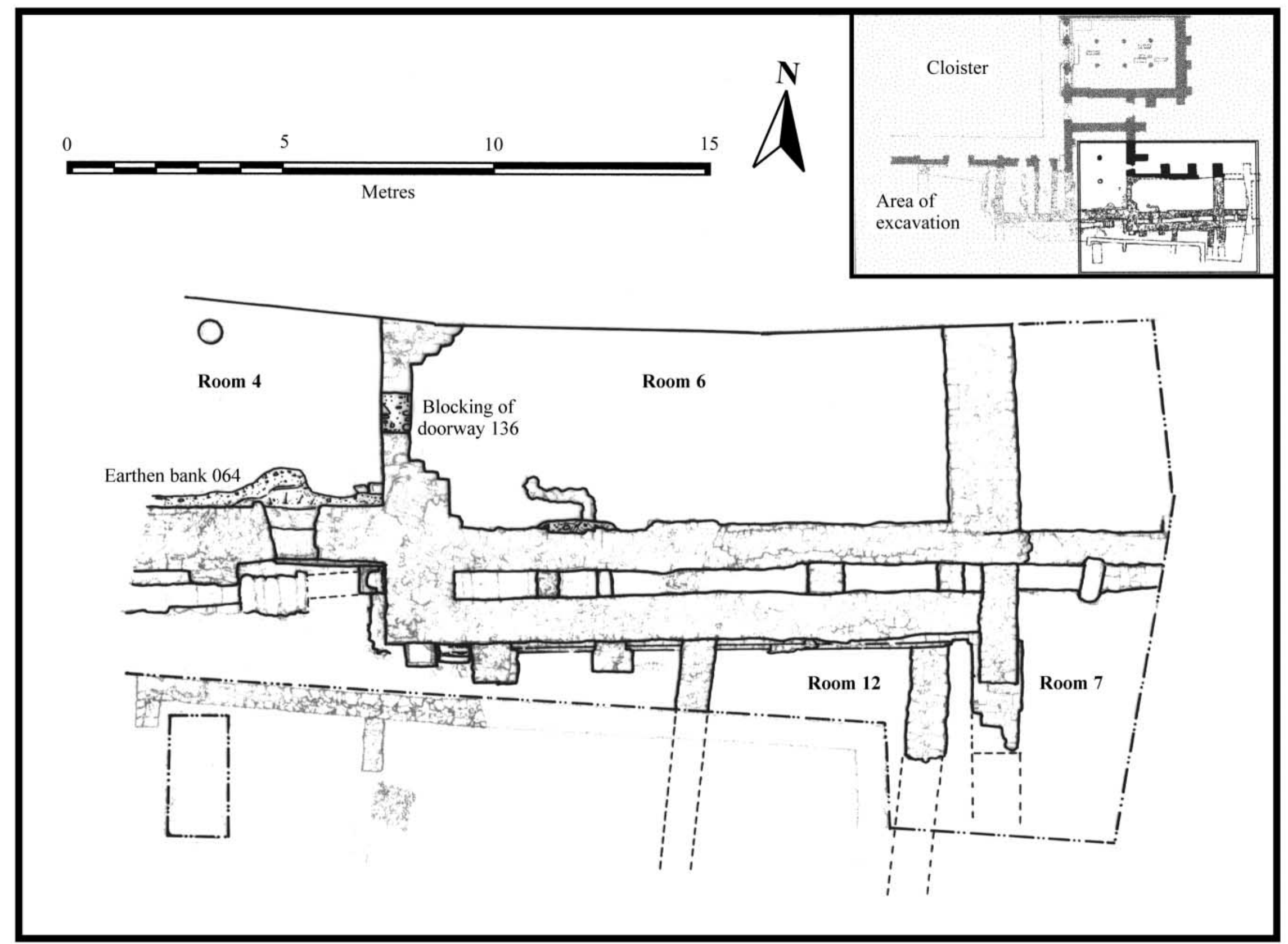




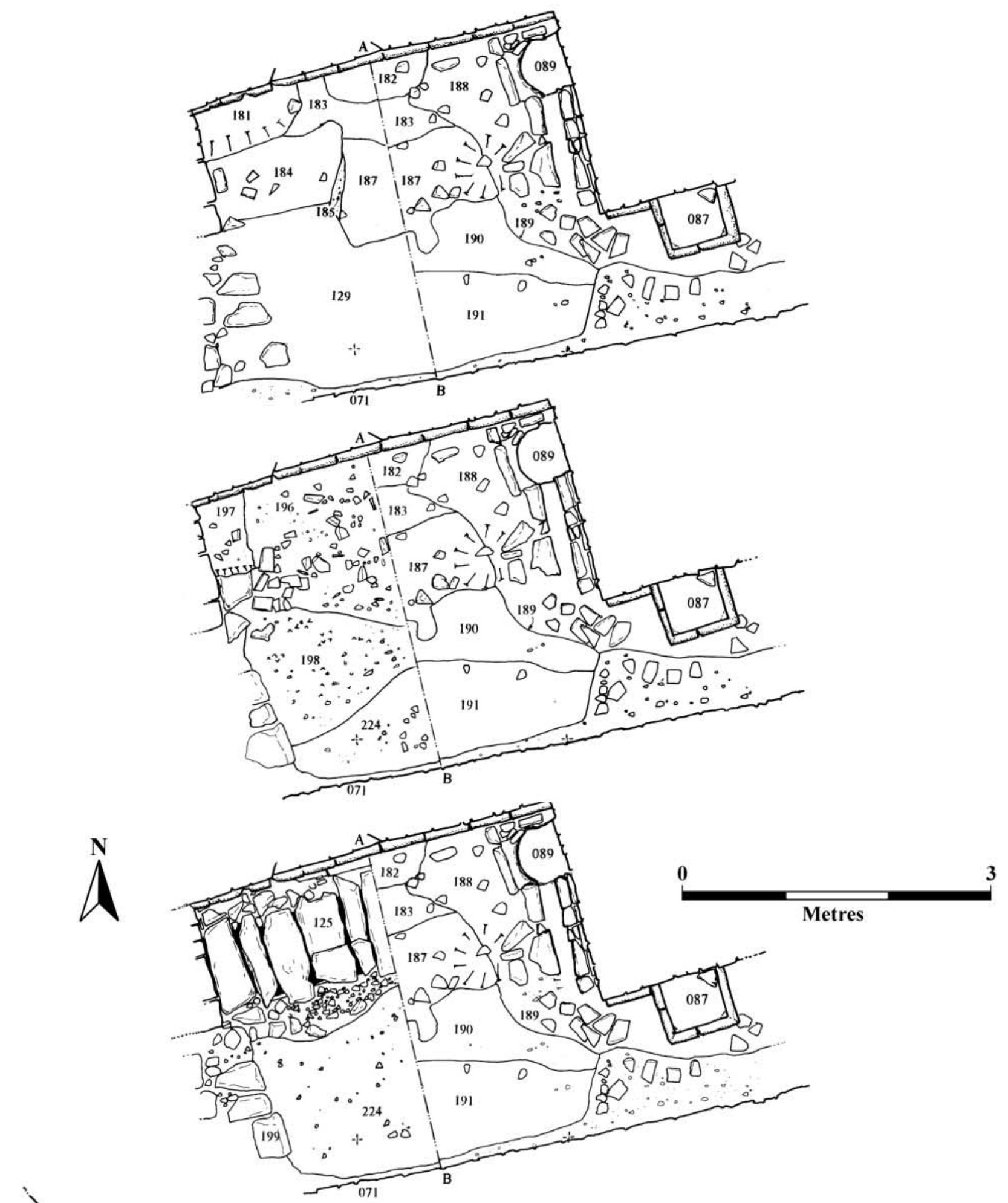

A

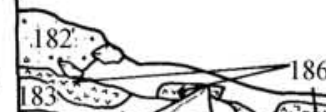



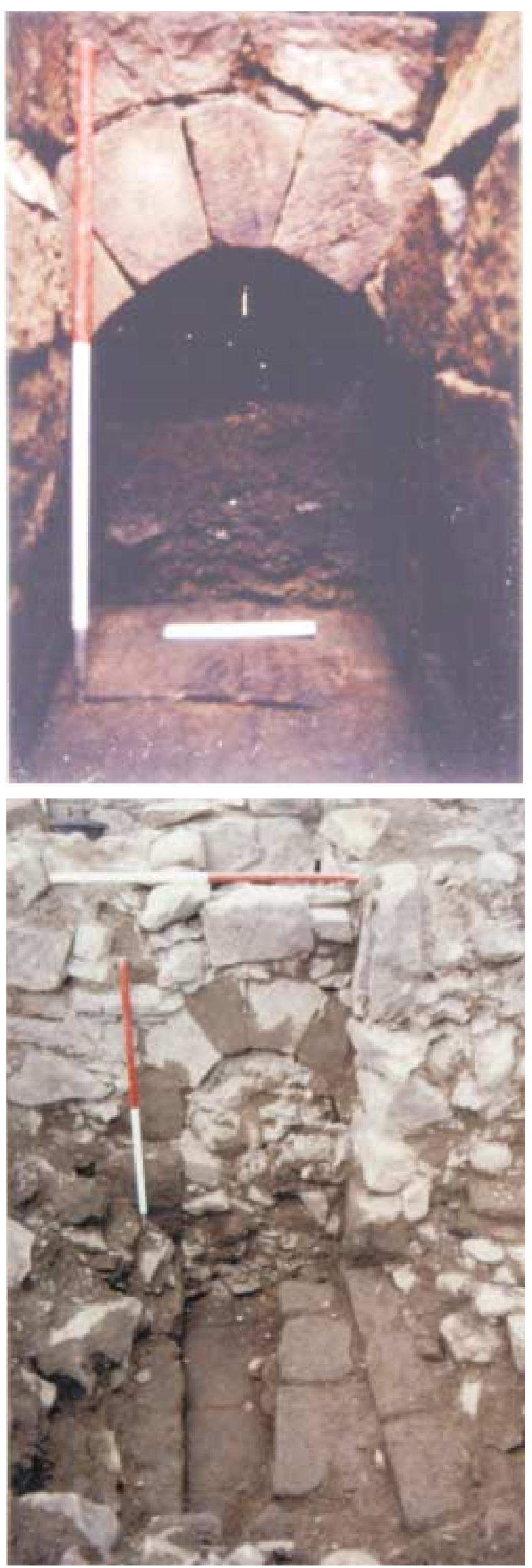

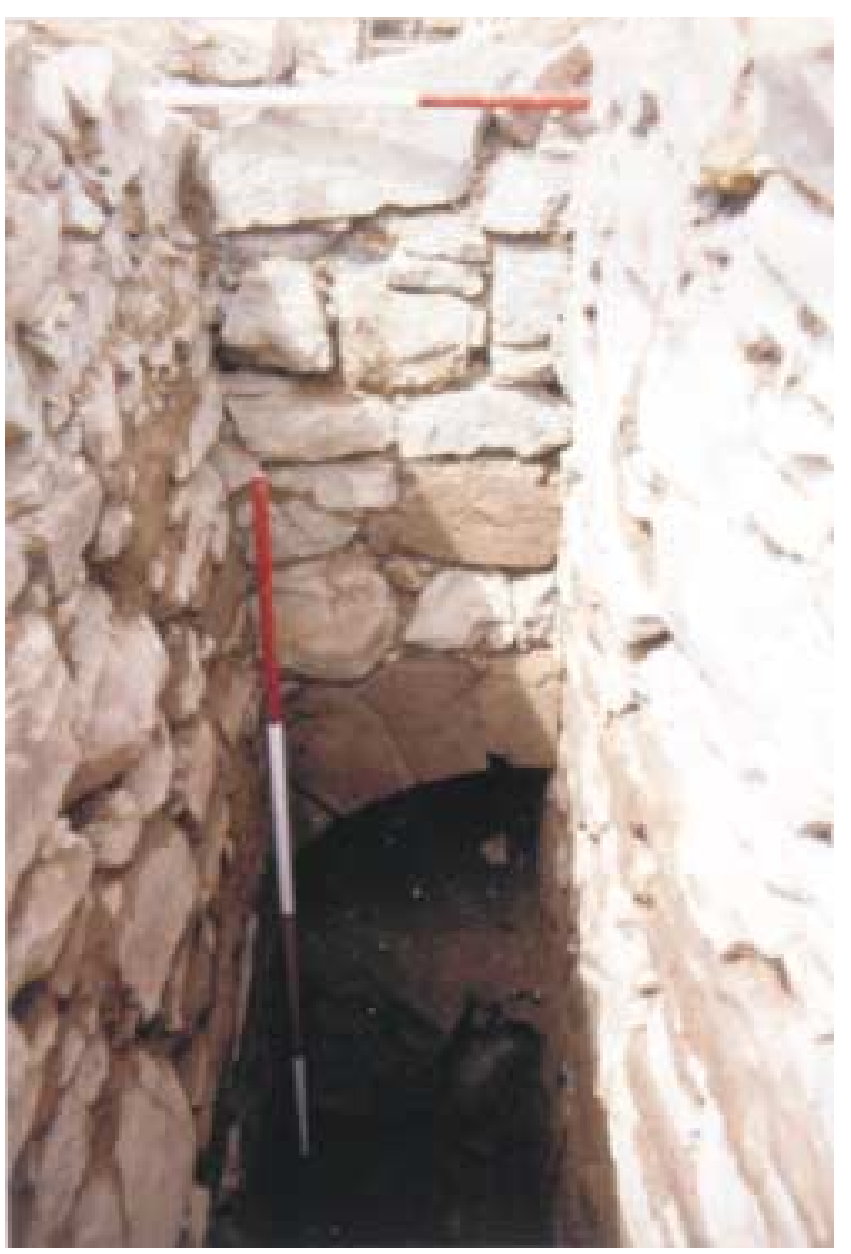

Illus 28 (top left) Great drain fills

\section{Illus 29 (top right) Great drain fills}

Illus 30 (lower left) East end of the great drain, before excavation

the latrine block. During the excavation of deposits over the Period III drain caps it became clear that a series of shallow midden deposits had accumulated, deposits which emanated from the latter stages of occupation within the adjacent chambers (rooms 4 and 6 ). The presence of the Period IV garderobe pit (context 089), and the probability that the latter was cleared by hand, also suggested a source for this accumulation of midden material. The midden broadly represented a dated sequence of deposits, culminating with demolition debris from the collapse of the buildings.

The drain capstones were bedded in recycled drain fill (context 222) and were sealed by two main groups of deposits. The primary group (contexts 196, $197 \& 198$ ) all featured peat ash and animal bone mixed with increasingly clay- and mortar-rich spreads towards its upper surface. The primary series of dumps were in turn sealed with a spread of roof slates set in gravel (contexts $194 \& 195$ ). The later sequence of dumping featured increasing amounts of peat ash and charcoal as well as large 
numbers of animal and fish bone. A billon penny of James IV (see 7. Small finds) was retrieved from the lowest deposit within this group (context 193), suggesting an early 16th-century date for deposition. With upper deposits (eg contexts $181 \& 182$ ), rubble and mortar increasingly sealed the midden sequence, and these represent the terminus ante quem for the occupation of the area prior to its active demolition.

This short sequence of deposits probably represents debris from domestic occupation of the ranges during Period IV and V at a time when the monastic community was first reduced in size, with this part of the site later converted to a series of cellars. Nonetheless, these deposits indicate a significant presence on the site at least during the first part of the 16th century, with access to imported goods and a wide range of local foodstuffs.

\subsubsection{Great drain fill}

Throughout the drain, the basal fills were generally similar sand- and gravel-rich water-borne deposits. These in turn were sealed directly at the east end of the drainage channel by rubble collapse. However, at the west end of the drain there was a distinct, almost peat-like sediment both overlying and sealed by more typical water-borne material. This sequence appeared to be the result of an accumulation of waste, probably associated with the use of the nearby garderobes (contexts 089 and 090), between intermittent periods of freely running water within the drain. The suggestion of periodic flooding is confirmed by the evidence of the detailed environmental analysis of drain fill samples, where soil conditions, plant species and insect remains suggest occasional inundation rather than consistent water flow.

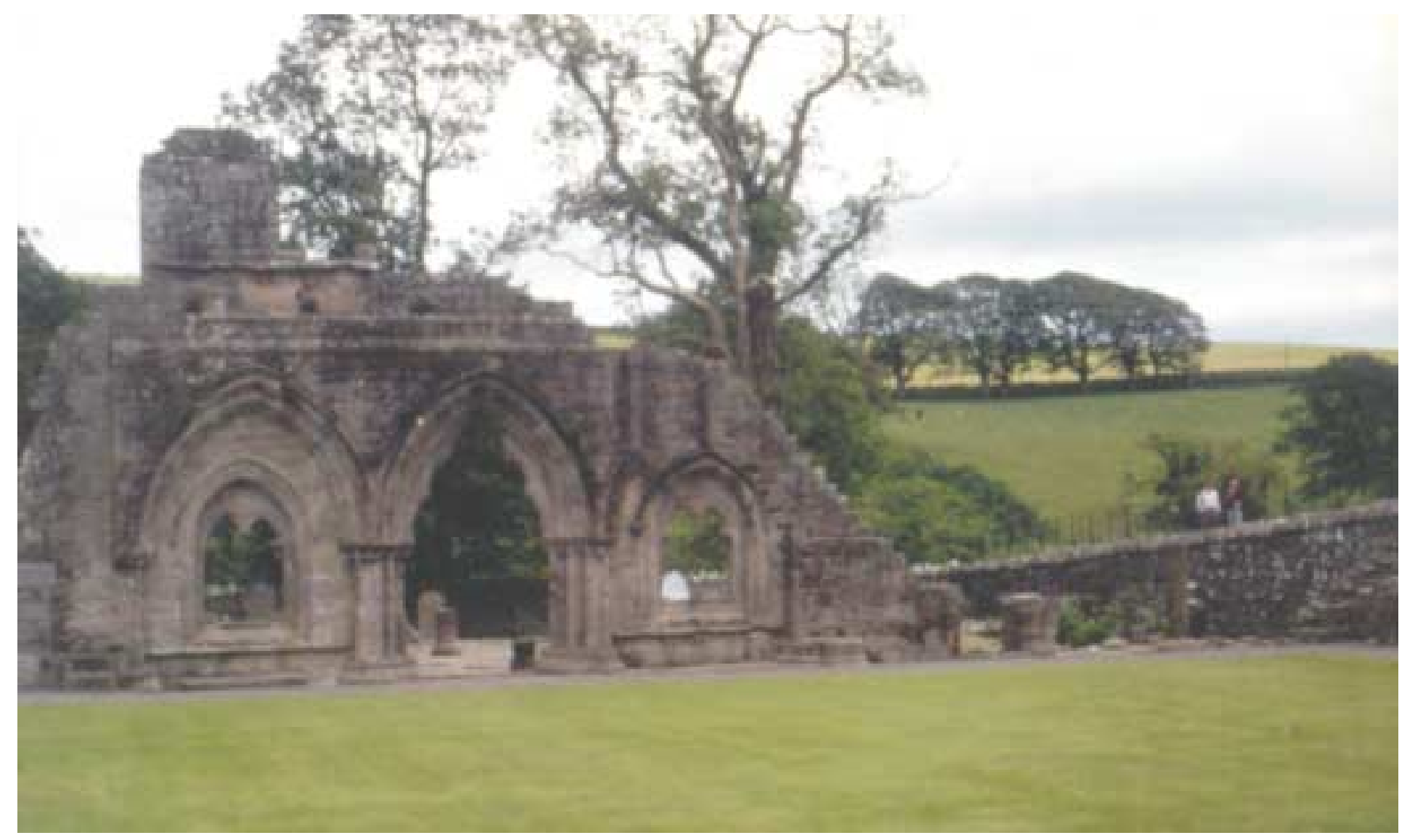

Illus 31 The chapter house 


\section{Geophysics and trial trenches by Gordon Ewart with GeoQuest Associates}

Six trenches were excavated in the field lying to the east of the abbey ruins following the completion of a resistivity survey by GeoQuest Associates (illus 32). The identification of only a small area of anomalies, which could not be accounted for by visible rig and furrow, led to the positioning of four of the trenches on topographical features. During this period of trial excavation, a contour survey of the area was carried out and a brief survey made of a bridge over the Abbey Burn, a short distance to the north-east of the area under investigation.

\subsection{Results}

Trenches $1 \& 2$ These were located primarily in order to locate the line of the abbey great drain on its route from the latrine to the Abbey Burn. The results can be summarised as reflecting extensive post-medieval agriculture, in terms of a policy of 'top-dressing' with introduced soils, mixed with stones and pot sherds, to facilitate drainage within the top $300 \mathrm{~mm}$ of the soil profile. These deposits in turn were farmed into broad rig \& furrow for strip cultivation. Significantly no trace was found of the abbey drain, although this may be due to the masking effects of post-medieval agriculture over truncated medieval features.

Trench 3 This was located across an east/west bank on the west side of the burn, thought to indicate the position of a boundary feature. A similar soil profile to that seen in trenches 1 and 2 was noted, but the possibility of deeper archaeological horizons associated with the abbey was suggested by a shallow, linear slot. The bank, however, proved to be a soil accumulation arising from post-medieval ploughing activity.

Trenches $4 \& 5$ Both of these trenches showed how residual features had been truncated then sealed by attempts to improve field drainage. A shallow ditch was found in trench 4, probably a structural feature, while a modern drystone revetting wall was identified in trench 5.

Trench 6 This was placed on the east facing slope to the north-east of the abbey church. A high resistivity anomaly formed a right-angle which corresponded to visible features, possibly indicating a building platform. The excavation confirmed the presence of a building platform, the massive scale of which, and its layered construction, with dumped, redeposited clays over a rammed clay surface, suggested that it was of monastic origin.

\subsection{Conclusions}

With the exception of trenches 1 and 2 , all excavated areas produced evidence of in situ archaeological deposits over a wide area. It appears from trenches 4-6 that the whole of the east- facing slope is artificially modified for arable purposes, but that most of this landscaping occurred after the abbey was abandoned. In general, the potential medieval features found in trenches $5 \& 6$ reflected attempts to create dry and stable building platforms, most likely for timber buildings, and probably associated with the earliest monastic colonisation of the site. 


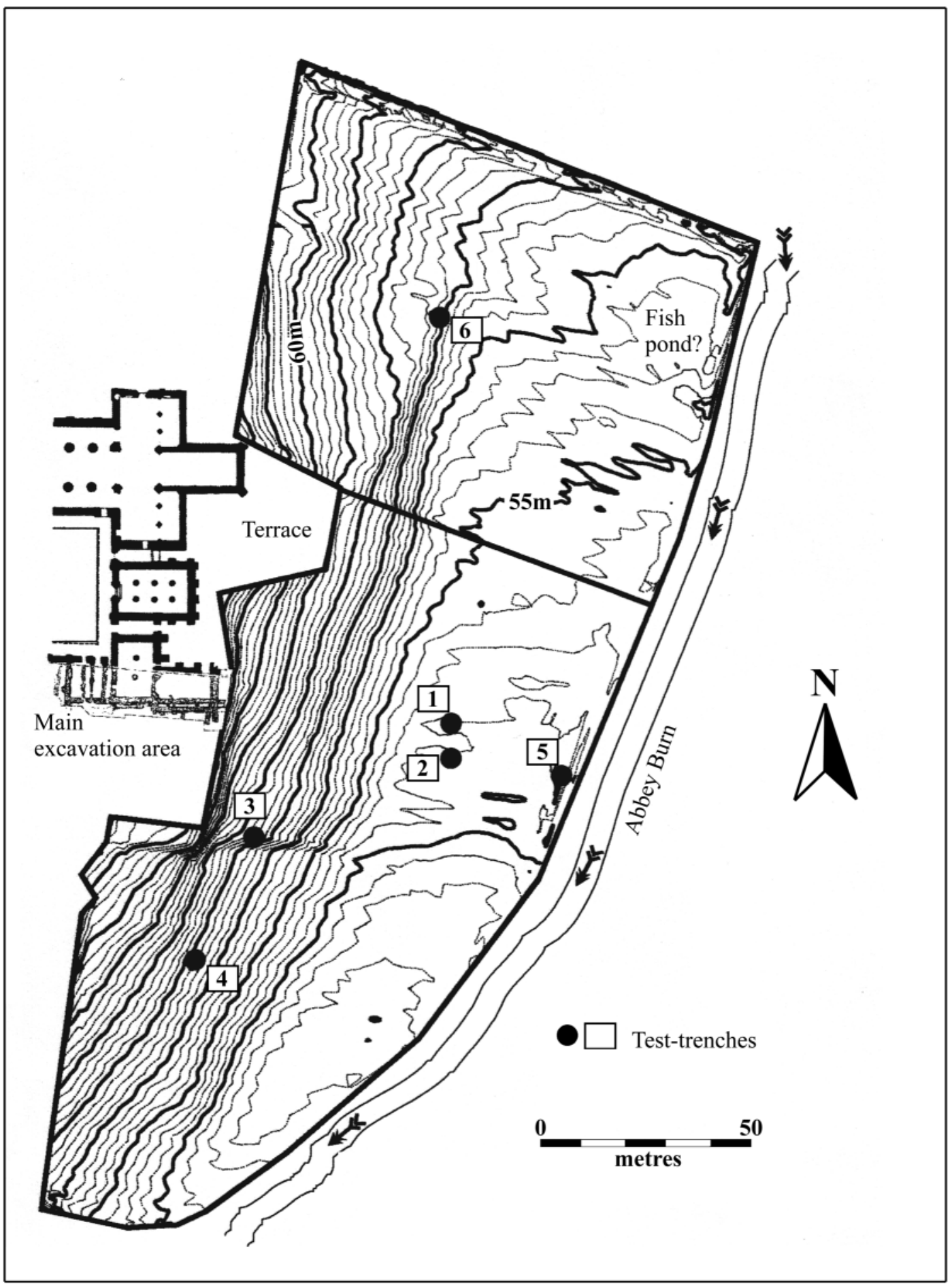

Illus 32 Contour survey and test-trenches east of the abbey 


\section{Ceramics by Alan Radley \& Bob Will}

The excavations produced a total assemblage of 372 sherds ranging in date from the 13th to the 20th century. Within this small assemblage there were 226 sherds dating from the 18th, 19th and 20thcentury occupation of the site and these are not described in detail. The remaining 146 examples are described as a series of ceramic types per archaeological period. The typology is based largely on the major ceramic assemblage recovered by excavations in St Andrews, Fife (Haggarty \& Will 1996). The distribution of the full ceramic assemblage (including the 18 th to 20 th-century material) is presented in illus 33 .

In the 13th century, reformed Benedictine orders such as the Cistercians took advantage of generous grants of land and channelled their efforts principally into wool production, often for export. Alongside the development of this important trade with Europe, monastic houses such as Dundrennan appear to have stimulated the production of locally made wheel-thrown pottery in previously aceramic areas. Despite its small size, the assemblage retrieved from 12th and 13th-century contexts establishes early Dundrennan as part of a much wider tradition of pottery manufacture in Scotland.

The medieval and post-medieval assemblage consists of both local and imported fabrics from Britain and mainland Europe, concomitant with an established network of trade links and revenues. Significantly, many of the imported wares are from France and Spain, indicating a west coast trade route and contact with the Gascon wine trade during the 15th and 16th centuries. Further evidence of European contacts is suggested by two 17th-century vessels in a local post-medieval redware fabric, which proved to be copies of Raeren stoneware drinking mugs (nos. 1 and 2, illus 34).

Over half the total number of sherds recovered from the site date from the later 19th century. The landscaping of the mounded debris over those buildings recently excavated appears to have seen some household rubbish disposal at about the same time, probably from the neighbouring manse. Large numbers of fragments of household crockery, storage jars and bowls were found, along with several ink pots, a ceramic hot water bottle and a small jar for hair restorer.

\subsection{Ceramics by period}

Periodisation of the ceramic assemblage is somewhat problematical. The frequent repair and rebuilding of the buildings of the south range, as well as post-abandonment taphonomic processes, has meant that much of the pottery occurred in disturbed or residual contexts. These factors, coupled with problems inherent in the dating of Scottish ceramic assemblages, have resulted in a periodisation (below) which is occasionally at odds with the more specific chronology derived from the archaeological stratigraphy and building sequence. With this caveat in mind, the following offers an abbreviated summary of the incidence of pottery types by period and provenance:

$\begin{array}{lll}\text { Period I } & \text { Type } & \text { Local; Scottish white gritty ware } \\ & \text { Total } & \text { 41 sherds } \\ & \text { Vessel types } & \text { Cooking pot } \\ & \text { Date range } & \text { 12th-14th century } \\ \text { Period II } & \text { Type a } & \text { French import; Saintonge green } \\ & & \text { glaze ware } \\ & \text { Total } & \text { 8 sherds } \\ & \text { Vessel type } & \text { Jug } \\ & \text { Date range } & \text { Mid 13th to late 14th century } \\ & \text { Type b } & \text { Local; Scottish medieval redwares } \\ & \text { Total } & \text { 16 sherds } \\ & \text { Vessel type } & \text { Jugs } \\ & \text { Date range } & \text { Late 13th to late 14th century } \\ \text { Period III } & \text { Type } & \text { French import; Loire region } \\ & \text { Total } & \text { Spanish/Portuguese import } \\ & \text { Vessel type } & \text { 14 sherds } \\ & \text { Jags } \\ \text { Date range } & \text { Late 14th to 15th century } \\ \text { Period IV } & \text { Type } & \text { Local; Scottish post-medieval } \\ & & \text { reduced wares } \\ & \text { Total } & \text { 11 sherds } \\ & \text { Vessel types } & \text { Jugs, bowls } \\ & \text { Date range } & \text { Late 15th to mid 18th century } \\ \text { Type } & \text { Local; iron glaze ware } \\ & & \text { Local; Scottish post-medieval } \\ & \text { reduced wares } \\ & & \text { French Import; Beauvais } \\ \text { Period V } & \text { stoneware } \\ & & \text { French import; Martincamp flask } \\ & \text { Total } & \text { J6 sherds } \\ & \text { Vessel types } & \text { Jugs, bowls, flasks and plates } \\ & \text { Date range } & \text { Late 15th to early 17th century } \\ & & \end{array}$

\subsection{Catalogue of illustrated ceramics (illus 34)}

1. Two conjoining sherds forming the base and most of the body of a small-handled drinking vessel. Hard red earthenware fabric with a very dark green/black iron glaze throughout. The vessel has a round foot and a bulbous lower body, tapering to a more regular cylindrical profile at its upper part and rim. Two of five fragments of local copies of German vessels, produced in Raeren (see also no. 2). 17th-century. Context 153, backfill of trench over drain, Period V.

2. Base and most of the lower body of a small- 


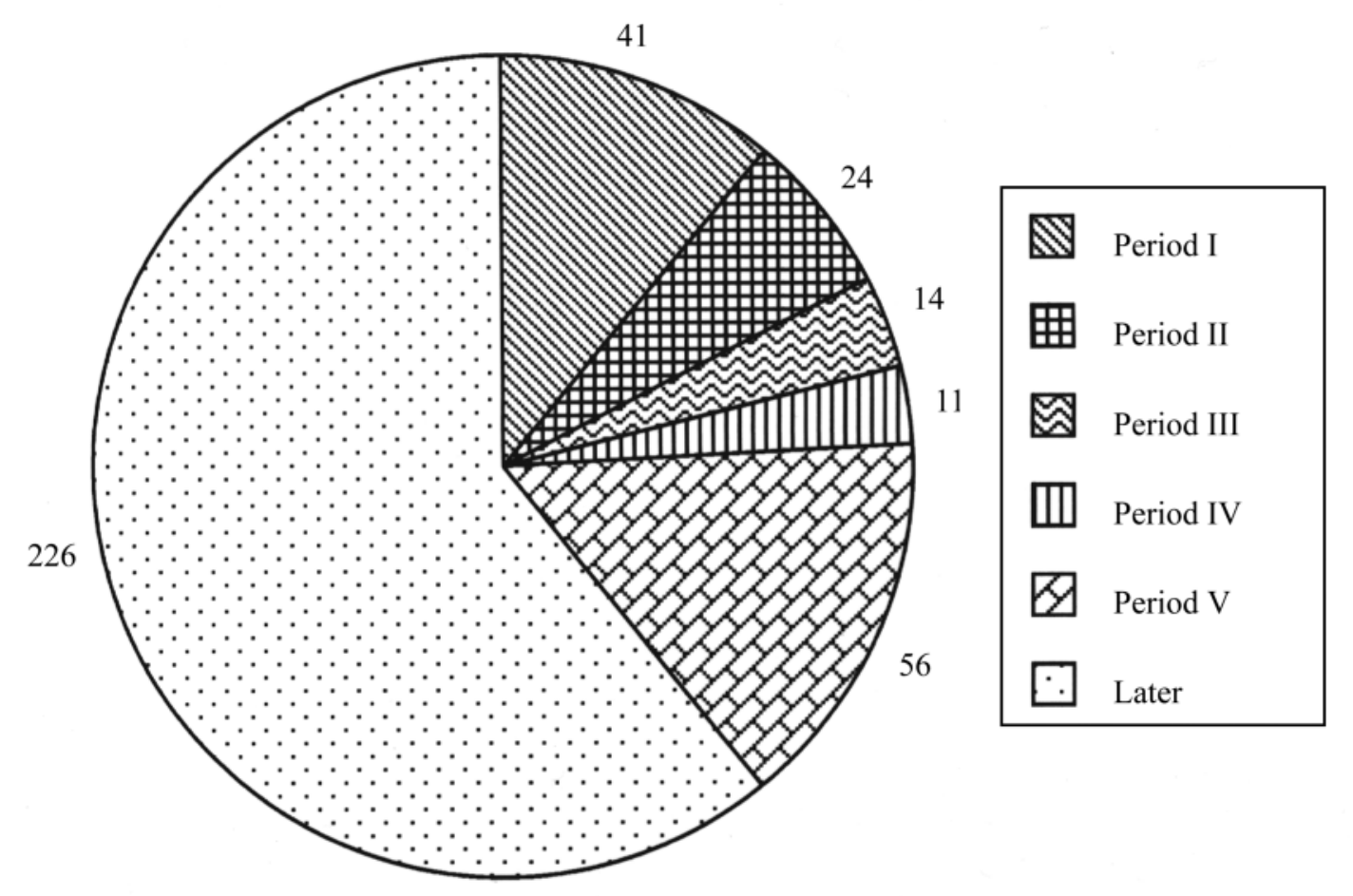

Illus 33 Pie-chart of ceramic sherds by period

handled drinking vessel. It has a hard, dark red earthenware fabric with very dark green/black iron glaze throughout. There is evidence of a single handle base fixed to the widest part of the lower body profile. Base of handle coincident with raised single line decoration. Similar to no. 1. 17th-century. Context 090, garderobe pit, Period IV.

3. Rim and body fragment of a large bowl with quite a wide rim projecting from the generally curving, almost rounded body profile (possible evidence of a lid setting). It is made from a coarse, (very gritty) pale cream/buff coloured fabric, heavily abraded externally. Internally there are splashes of green/yellow glaze around small pits, (where stone inclusions have fallen out during firing?), with drip lines down from them. This is an imported vessel, probably from Portugal or Spain. 15th-century. Context 158, remains of masonry vault, Period IV.

4. Rim and handle stub of a bowl. The rim features a band or frill decorated with incised lines with a very pale green/yellow glaze. The fabric is a soft, fine grained pale red ware. 13 th to 15 th-century. Context 158, remains of masonry vault, Period IV.

5. Lid fragment, approximately $25 \%$ of a circular lid. It is decorated with incised lines, radiating from the centre. The exterior or upper surface features a patchy red/brown, extremely gritty glaze. The interior is unglazed and the fabric is a slightly gritty, smoothed pale red ware. 13th to 15th-century. Context 175, raising of floor in room 9, Period II.

6. Part of the handle of a jug. It has a very smooth, cream/buff coloured fabric with a few red gritty inclusions. This is an imported vessel from the Loire region of France. 14th-century. Context 108, dumped clay and stones supporting south side of drain, Period II.

7. A body fragment, with handle stub, probably of a locally produced 'pirlie pig' money box. It has a rilled exterior with external green glaze over red fabric reduced to grey. 15th-century. Context 158 , remains of masonry vault, Period IV. 

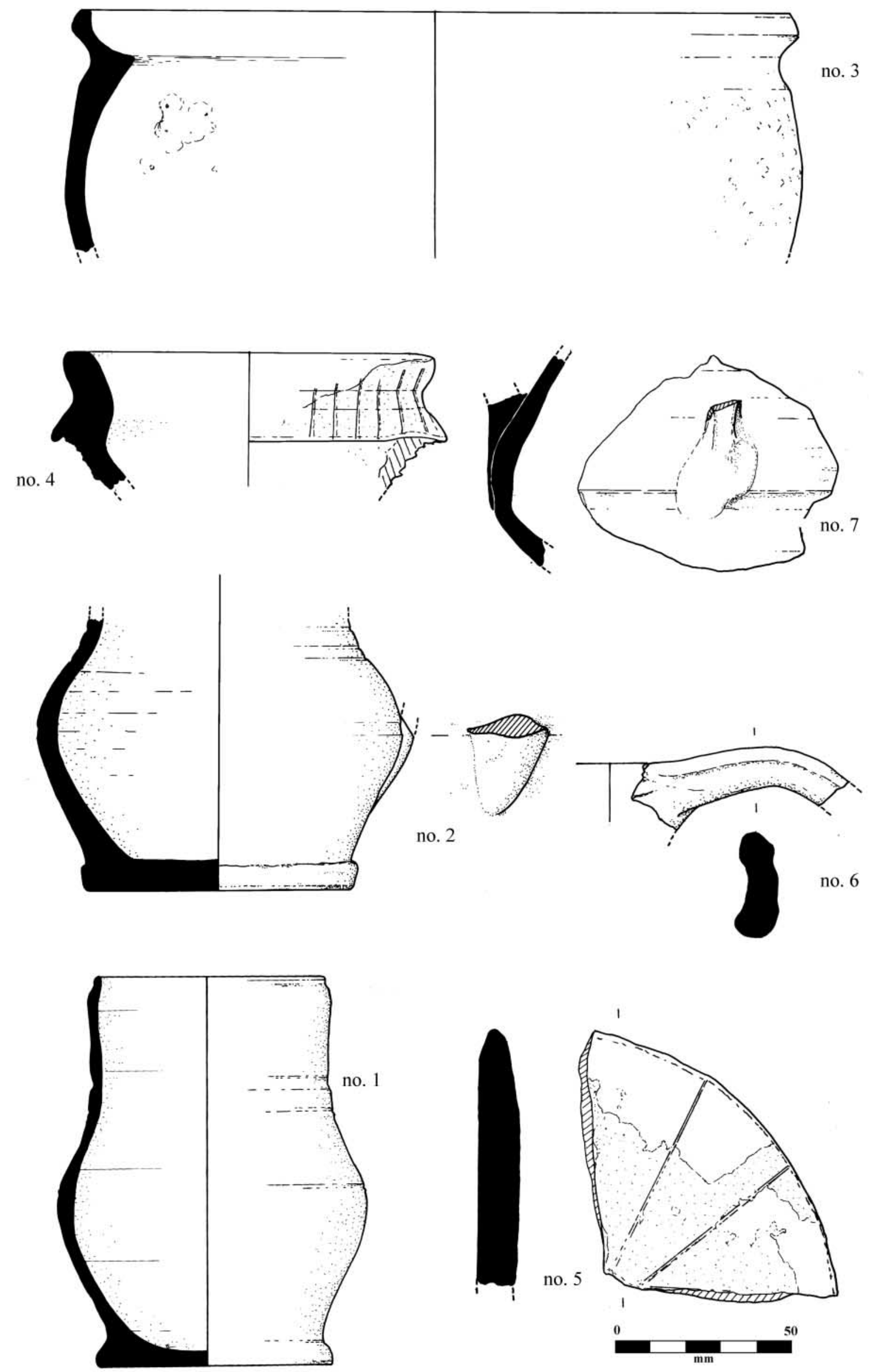

Illus 34 Selected ceramics 


\section{Small finds by Andrew Dunn}

A total of 48 small finds is presented here, including a representative illustration of the window cames. The majority derives from either the fill of the great drain or the accompanying midden deposits. As such, the small finds can provide dating evidence and other information relating to the formation of the midden and the filling of the drain. The finds are presented below in catalogue form, according to material type.

\subsection{Metal objects}

A silver spoon (no 1) was recovered from a late rubble deposit. In Emery's (1976) classification this is a 'ficulate' type, with a date range in England from the end of the Hundred Years' War to the Restoration (see Emery 1976, fig 33.ii, for the closest parallel). The style, thought to originate in Italy, where early ficulate spoons are dated to the 14th and 15th centuries, was later adopted in France and England. Like the Dundrennan example, spoons of this type were often too big to be inserted wholly into the mouth and would probably have been soup-spoons, rather than, say, used in a liturgical context (as might have been the case in an early medieval monastic context). A 16th-century date for the spoon is not unreasonable. The form and decoration marks the spoon as a local variant, being quite unlike most examples found elsewhere in Europe.

Several pins were recovered, both in silver and in copper alloy. The introduction of (brass) wire pins to Britain dates to 1543 (Tylecote 1972), and the fashion of forming a globular head by means of two or more twists at the head dates to the same period. The tradition continued until the end of the 18th century, but the Dundrennan pins should be placed earlier in this range, as they have fewer twists in the globular head. A late 16th-century date is appropriate, although pins of this type continued in use for at least 150 years.

XRF analysis of the ingot (no. 17) was undertaken at AOC Archaeology Ltd and the National Museums of Scotland. This revealed it to be of a copper and lead compound composition. The object may be the waste product of silver refining, although whether this was carried out on site is not known.

In addition to the objects described below, quantities of lead window came were also recovered (eg illus 38 , no 40).

\subsubsection{Catalogue of metal objects}

1. Spoon (illus 35) A large silver spoon, measuring $145 \mathrm{~mm}$ in length, with a large bowl and an 85 $\mathrm{mm}$ handle, tapering to a lozenge-sectioned terminus (knop). The knop is decorated on all four sides, and on the end with a cross. Context 012, rubble deposit, Period V.

2. Pin Silver pin measuring $35 \mathrm{~mm}$ in length, with wire-wound head. $3 \mathrm{~mm}$ in section. Context 043, hearth in room 8, Period I (the pin is of a later date and likely to be intrusive in this context).

3. Key (illus 37) Iron key, badly corroded, measuring $85 \mathrm{~mm}$ in length and with circular end. Context 141 , from surface of unexcavated deposit in southeast corner of room 4, Period unknown.

4. Pin Silver pin with wire-wound headed, head slightly flattened. Measures $35 \mathrm{~mm}$. Context 129, upper midden deposit, Period IV.

5. Pin Silver pin with wire-wound head. $23 \mathrm{~mm}$ in length. Context 129, upper midden deposit, Period IV.

6. Pin Silver pin with slightly flattened head, very fine in section, $c 20 \mathrm{~mm}$ in length. Context 191, upper midden deposit, Period IV-V.

7. Coin Francis \& Mary hardhead/Lion, type II, minted 1559-60, countermarked with heart and star when recalled under James VI in 1575. Probably lost soon after 1575. Context 174, upper midden deposit, Period IV-V.

8. Lace tag Copper-alloy lace tag, $25 \mathrm{~mm}$ in length, formed from a single piece of copper alloy, wrapped around to form a hollow cylinder. Traces of leather within. Context 183, upper midden deposit, Period IV.

9. Needle (illus 35) Copper-alloy needle, $63 \mathrm{~mm}$ long, with ovoid eyehole, and tapering to a point. Head slightly flattened. Context 193, upper midden deposit, Period IV.

10. Heel Iron heel support, horseshoe-shaped with three spikes to attach to the heel; $c 40 \mathrm{~mm}$ by 40 $\mathrm{mm}$, and $2-3 \mathrm{~mm}$ thick. Context 200, bracing within the latrine shaft, Period IV.

11. Pin Fragment of copper-alloy pin, $13 \mathrm{~mm}$ in length. Context 184, upper midden deposit, Period IV.

12. Lace tag Copper-alloy lace tag, formed in same manner as no. 8, measuring $20 \mathrm{~mm}$ in length. Context 129, upper midden deposit, Period IV.

13. Pin Copper-alloy/silver pin, wire-wound head, length $52 \mathrm{~mm}$. Context 196, lower midden deposit, Period IV.

14. Pin Copper-alloy/silver pin, wire-wound head, length $35 \mathrm{~mm}$. Context 196, lower midden deposit, Period IV.

15. Pin Copper-alloy/silver pin, head missing, length $36 \mathrm{~mm}$. Context 196, lower midden deposit, Period IV.

16. Lace tags Five copper-alloy lace tags; four are 15 
no. 21

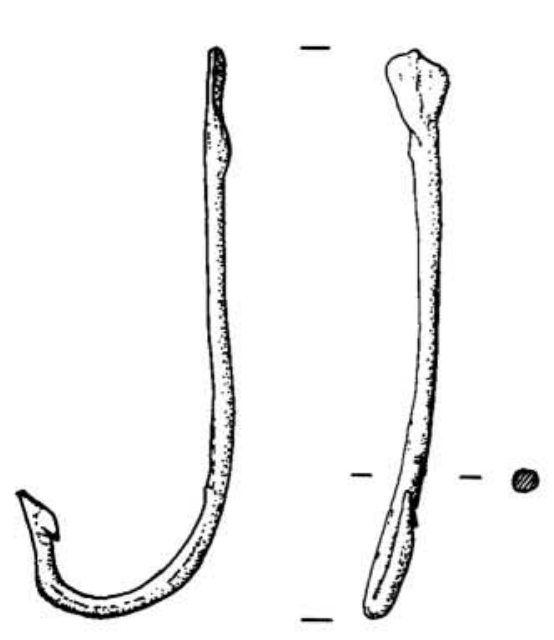

no. 9

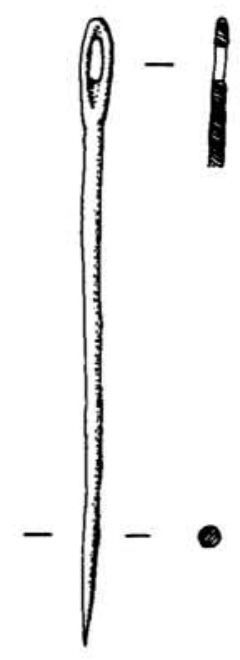

no. 19

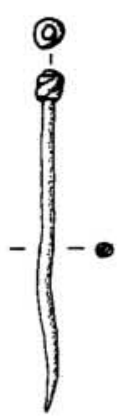

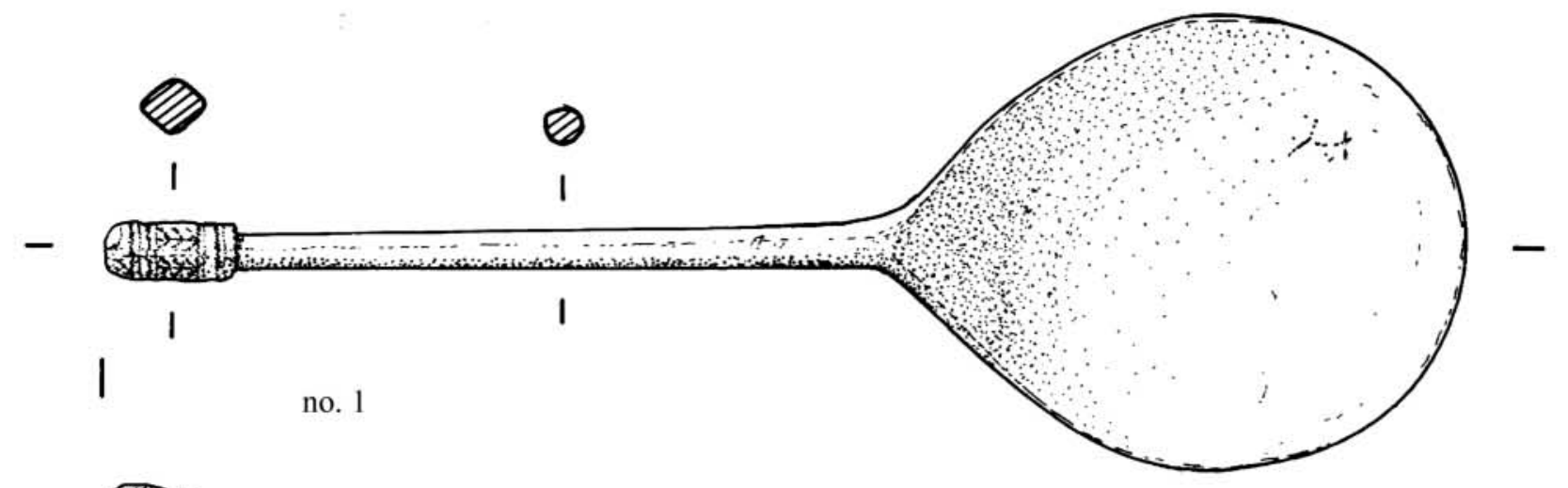

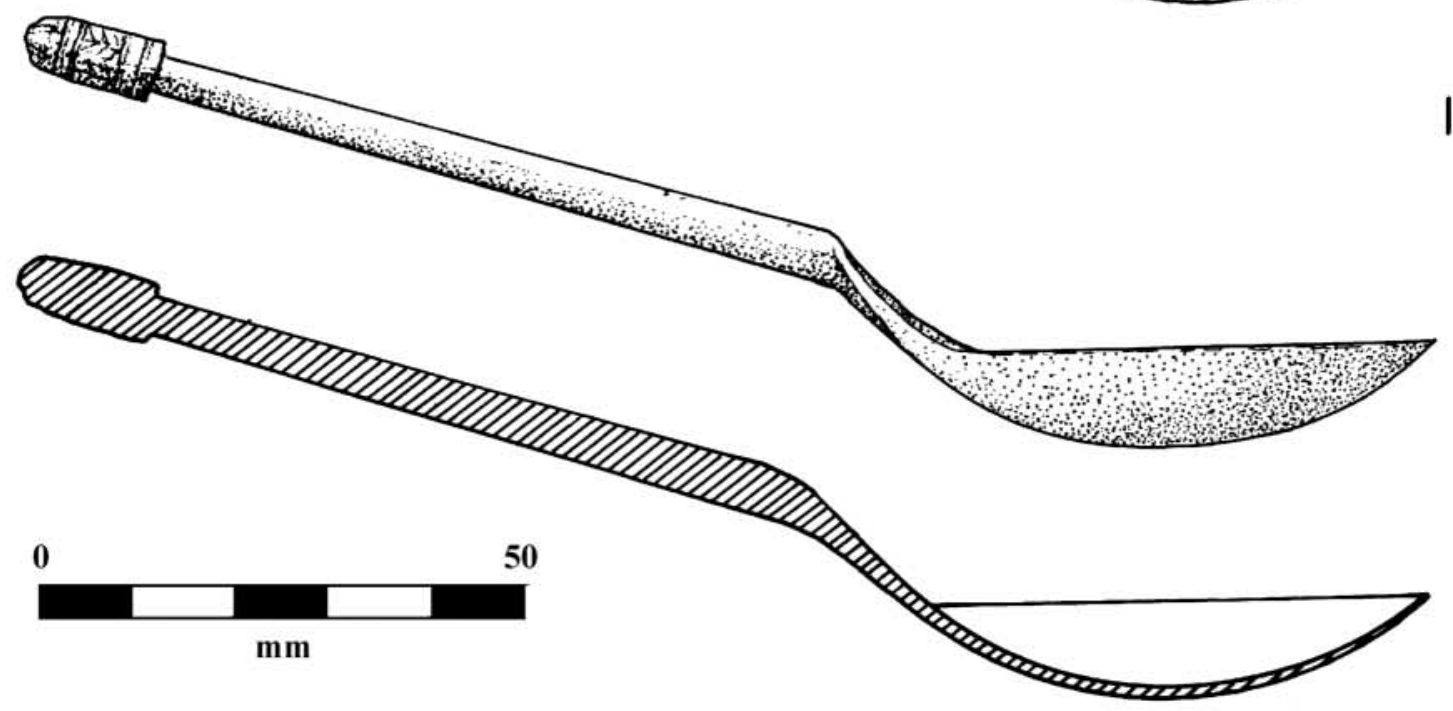

Illus 35 Silver spoon; copper-alloy fish-hook, needle \& pin 
0
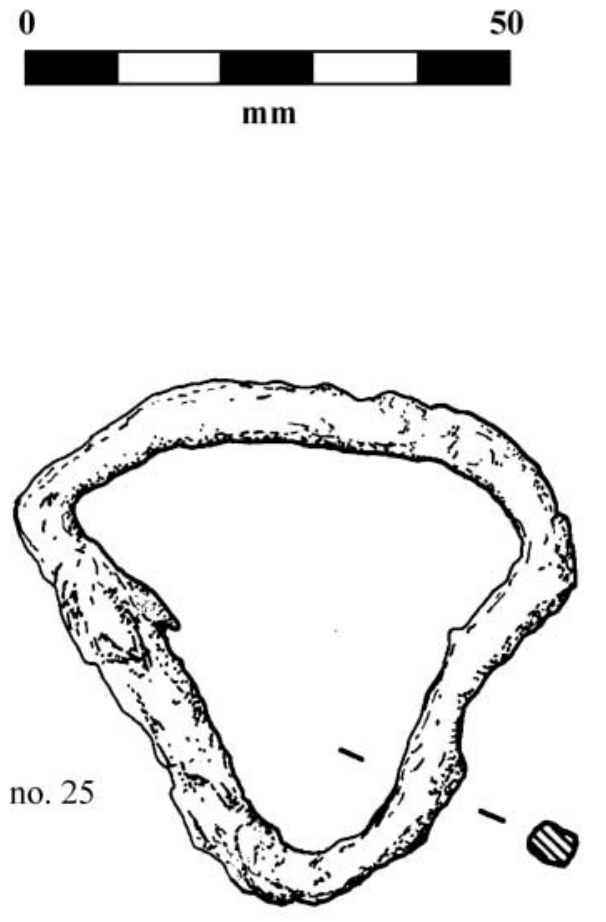
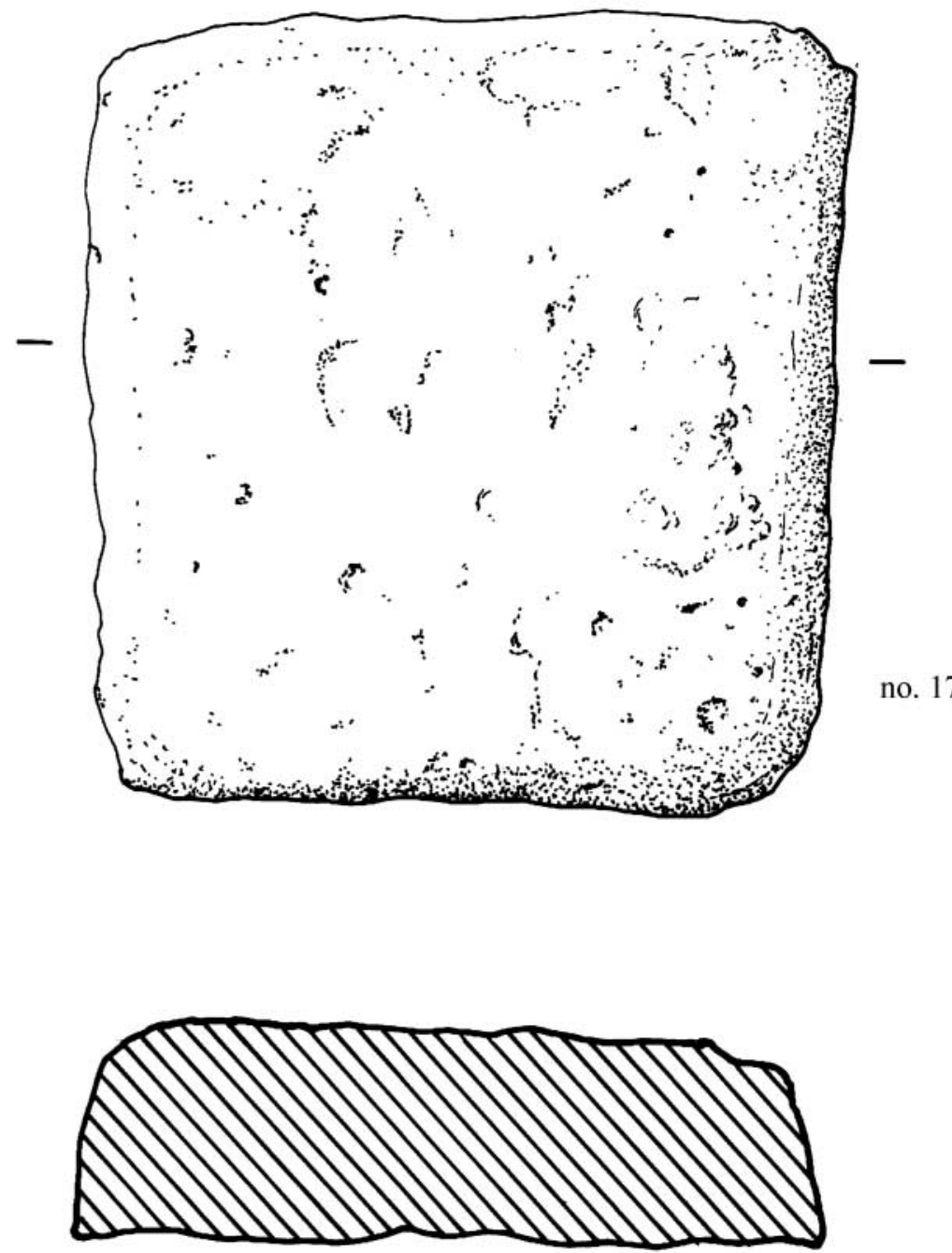

Illus 36 Compound ingot and iron belt loop

$\mathrm{mm}$ long, one is $11 \mathrm{~mm}$. Two contain traces of leather lace. Context 198, lower midden deposit, Period IV.

17. Ingot (illus 36) Copper-alloy ingot, square in plan and $18 \mathrm{~mm}$ thick, sides measuring $80 \mathrm{~mm}$. Irregular corroded surfaces with no trace of markings. Weight c 945 g. Context 198, basal drain fill, Period IV.

18. Lace tags Three copper-alloy lace tags, measuring $21 \mathrm{~mm}, 15 \mathrm{~mm}$ and $16 \mathrm{~mm}$. Two retain traces of leather. Context 222, debris from insertion of drain caps, Period IV.

19. Pin (illus 35) Copper-alloy pin with wire-wound head, $33 \mathrm{~mm}$ long. Context 171, drain in floor, room 5, Period IV-V.

20. Ring / quoit (illus 37) Large iron ring, $123 \mathrm{~mm}$ by $110 \mathrm{~mm}$ with a hole of $53 \mathrm{~mm}$ diameter. Flat base with sloping sides. Possibly part of a wheel fitting. Unstratified.

21. Fish hook (illus 35) Copper-alloy fish hook, 70 $\mathrm{mm}$ long. Single barbed tip and splayed opposite end. Not unlike some published English examples (eg illustrated in Steane \& Foreman 1988), a common form of hook throughout the medieval period. Unstratified.

22. Iron object Four conjoining plate fragments, with a possible rivet at one end. Context 227, floor of room 5, beneath collapsed vault, Period II.

23. Ring/ring brooch Plain circular ring of copper alloy, possibly part of a ring brooch (no pin was present), $20 \mathrm{~mm}$ in diameter. Context 231, latest occupation deposit room 4 , Period V.

24. Spearhead Socketed iron spearhead, originally lozenge shaped in section. $130 \mathrm{~mm}$ long and 30 $\mathrm{mm}$ wide at the base. Context 278, levelling over collapsed vaulting, Period IV.

25. Belt loop (illus 36) Iron belt loop, triangleshaped, pinched in on two sides. Max $55 \mathrm{~mm}$ across. Context 279, late occupation or midden deposits over collapsed vaulting in room 5, Period IV.

26. Plaque Small, roughly square piece of copper alloy, $15 \mathrm{~mm}$ by $15 \mathrm{~mm}$, with slight protrusions on one side. Context 279, late occupation or midden deposits over collapsed vaulting in room 5, Period IV. 


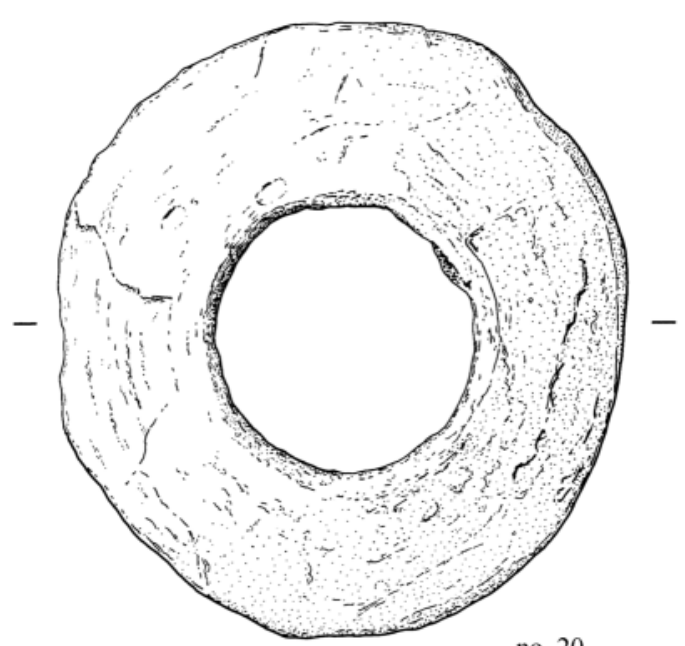

no. 20

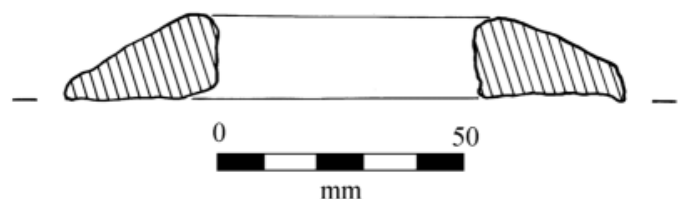

no. 3

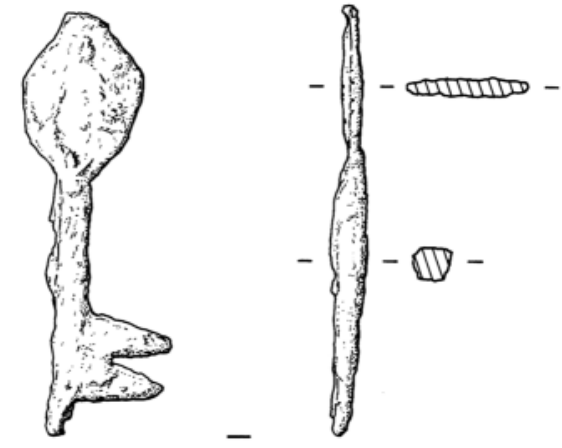

Illus 37 Iron quoit and key

27. Handle? Iron handle. Length $140 \mathrm{~mm}$, bent at end, with two holes to attach a handle. Context 256, rubble within drain fill, Period IV.

28. Scriptum? (illus 38) Lead object, pointed at both ends, $c 104 \mathrm{~mm}$ long. Possible scriptum or stylus. Context 253, silting in drain, Period IV.

29. Bead Copper-alloy bead. Small, sub-spherical bead, $6 \mathrm{~mm}$ across. Context 049, levelling material beneath floor in room 9, Period II.

30. Pin Copper-alloy/silver pin with wire-wound head, $32 \mathrm{~mm}$ long. Context 246, wall core and masonry collapse in room 5, possibly Period III.

31. Lace tag Copper-alloy lace tag, $15 \mathrm{~mm}$ long. Context 246, wall core and masonry collapse in room 5, possibly Period III.

32. Plaque Lead plaque, flat, with edges slightly raised, $32 \mathrm{~mm}$ by $27 \mathrm{~mm}$ and $3 \mathrm{~mm}$ thick. Context 267, basal drain fill, Period I.

33. Seal Lead seal, circular, with illegible relief markings; $19 \mathrm{~mm}$ in diameter. Context 223, bedding material for capstones, Period I.

34. Lace tag Copper-alloy lace tag, $12 \mathrm{~mm}$ long. Context 127, midden deposit, Period IV.
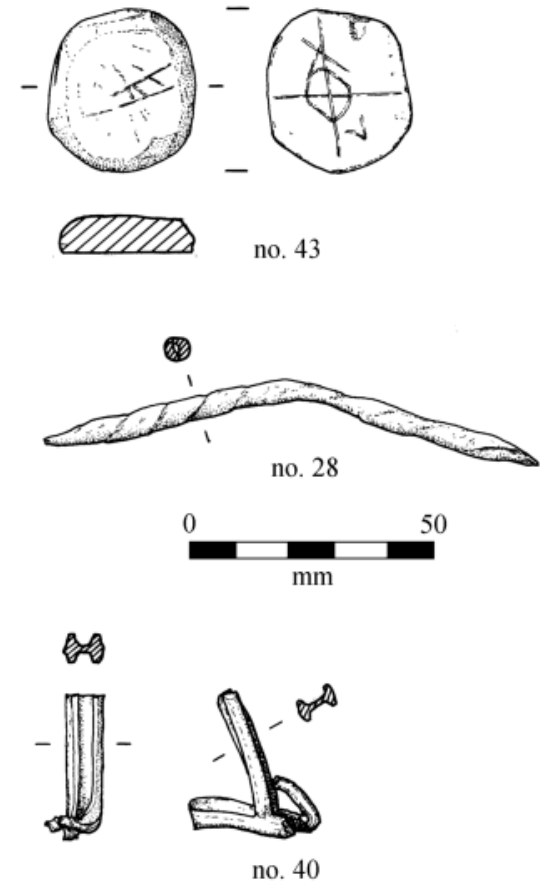

Illus 38 Stone counter, lead stylus and window cames

35. Hinge Copper hinge, with two nail holes on the flat side; $15 \mathrm{~mm}$ by $11 \mathrm{~mm}$. Possibly modern. Context 279, late occupation or midden deposits over collapsed vaulting in room 5, Period IV.

36. Lace tag Copper-alloy lace tag, $17 \mathrm{~mm}$ long. Context 198, midden deposit, Period IV.

37. Lace tag Copper-alloy lace tag, $15 \mathrm{~mm}$ long. Context 196, midden deposit, Period IV.

38. Coin James IV billon penny, minted $c 1500-10$, second issue, type II; lost before 1525. Context 193, midden deposit, Period IV.

39. Pin Copper-alloy pin with head hammered flat, $32 \mathrm{~mm}$ long. Context 184, upper midden deposit, Period IV.

40. Cames (illus 38) Two lead window cames with $\mathrm{H}$ profile. Context 196, lower midden deposit, Period IV.

\subsection{Other small finds}

\subsubsection{Leather (not illus)}

41. Shoe Five fragments from a leather shoe, including two rows of riveted eyeholes, one nailed heel, one length of copper alloy, and one unidentifiable piece of leather. The eyeholes number 10 and 9 respectively, with the rivets themselves being $5-$ $6 \mathrm{~mm}$ in size. The heel fragment measures $c 50$ $\mathrm{mm}$ by $60 \mathrm{~mm}$, and includes 23 copper-alloy nails. Traces of stitching also visible within the heel. Context 153, backfill of trench around drain, Period V. 

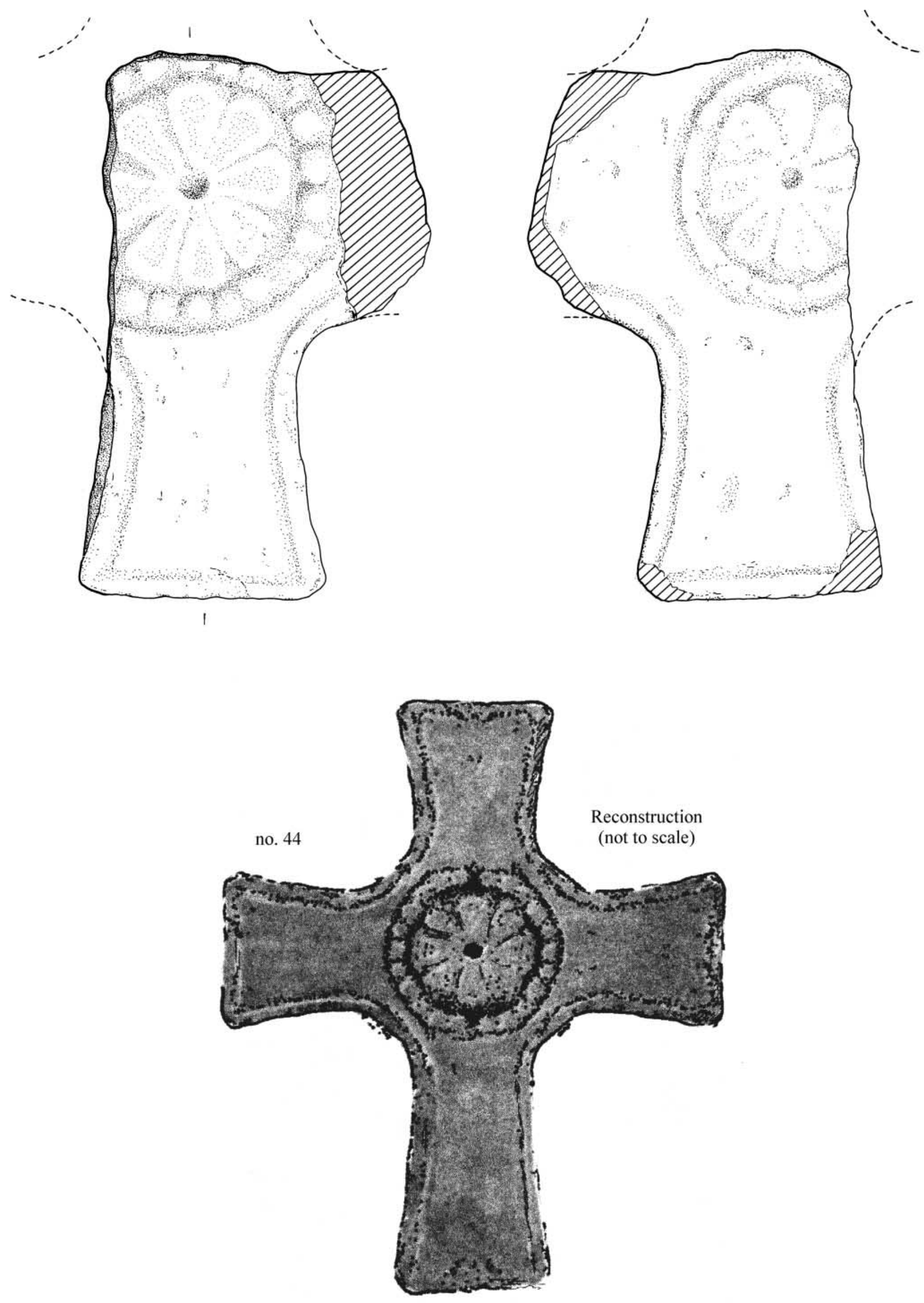

Illus 39 Stone cross 


\subsubsection{Stone}

42. Glazed pebble Oval pebble with one flattened edge, measuring $17 \mathrm{~mm}$ by $12 \mathrm{~mm}$. Banded appearance, traces of glaze. Possibly a gaming piece. Context 212, collapse from room 5, Period V.

43. Counter (illus 38) Roughly circular stone counter, decorated with a cross and circle on one side and crudely scored on the other. Width 30 $35 \mathrm{~mm}$, thickness $7 \mathrm{~mm}$. Context 161, cross-wall within drain channel, Period II.

44. Cross head (illus 39) Approximately a third of this carved stone survives, featuring part of an arm and decoration at the crossing (the remainder was probably broken off in antiquity). Eight lobes or 'petals' (these are not compass drawn) radiate from a central circle and, in turn, are surrounded by a series of relief bosses forming an encircling ring $210 \mathrm{~mm}$ in diameter. Possible traces of grooving define the side arms of the cross. $420 \mathrm{~mm}$ long and $230 \mathrm{~mm}$ wide max, up to $90 \mathrm{~mm}$ thick. Context 154, infill in room 5, Period V.

45. Counter Rounded slate counter, $40 \mathrm{~mm}$ diameter, $4 \mathrm{~mm}$ thick. No decoration. Context 137, midden deposit, Period V.

\subsubsection{Vessel glass (not illus)}

46. Rim sherd Fragment from rim of a fine decorated vessel, with two bands of painted stripes. Context 209, basal drain fill, Period IV.

47. Rim sherd Similar sherd to no 46, probably from the same vessel. Context 209, basal drain fill, Period IV.

48. Sherd Vessel glass sherd similar to nos. $47 \& 48$. Context 161, cross-wall within drain channel, Period II. 


\section{Window glass by Andrew Dunn}

In total, some 66 fragments of window glass were retrieved and conserved following the excavations in 1991. All were recovered from within a single pit, cut into the rubble infill of room 11, the refectory (context no 048/060, Period IV-V). Further fragments of painted glass were retrieved during subsequent excavations in 1992 and 1993 (mostly from contexts $127,197,198 \& 222$ ) but unfortunately these were not in a condition which allowed positive identification. The fragments represent a relatively large collection of Scottish medieval painted glass, and allow for comparison with other Scottish abbeys, most notably the major Augustinian house at Jedburgh, in Roxburghshire (Graves 1995).

Many of the sherds are of grisaille, where the surface of the glass is painted with iron and lead

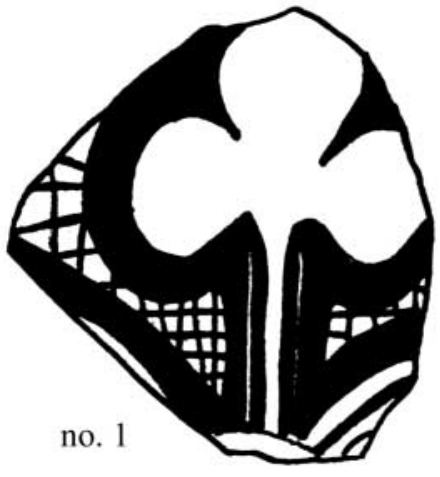

no. 3
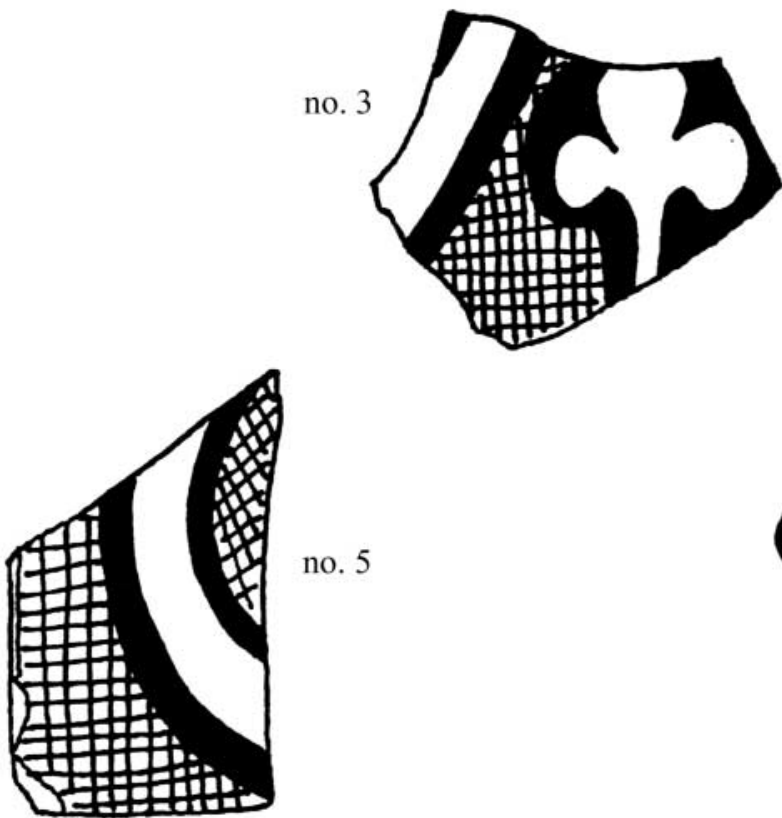

no. 5

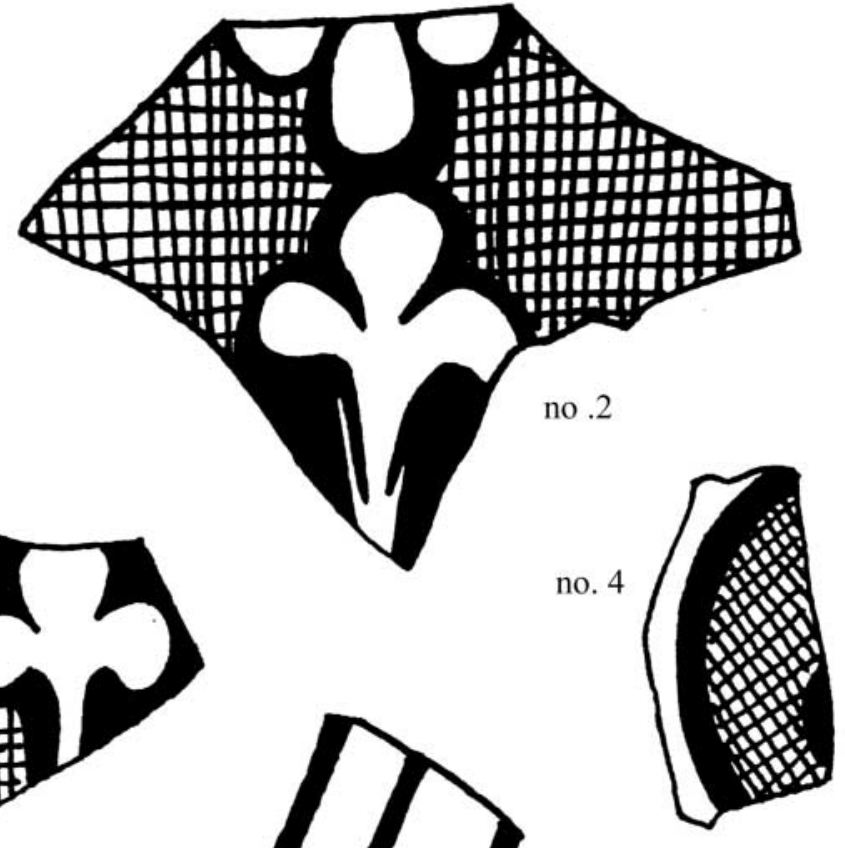

0

\section{0}

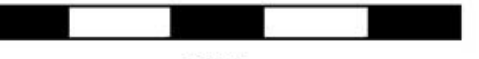

$\mathrm{mm}$ 
oxides mixed with gum arabic This results in the characteristic red/brown colour of the decoration. Grisaille glass generally formed the border to a more ornate panel of coloured glass, and as such was considered as being to some extent dispensable, being removed and renewed more often than the probably imported coloured glass.

No fragments of coloured glass were identified in the collection from Dundrennan, although the condition of the sherds, even after conservation, is such that their surfaces are heavily patinated, and no colour is visible. Where the sherds remain mostly transparent, no obvious colouring was recorded.

\subsection{Grisaille (illus 40)}

Much of the Grisaille glass shows signs of the characteristic cross-hatching decoration popular in the 13th century, alongside geometric banding and trefoil designs. The more naturalistic foliage designs and beaded borders reported from Jedburgh (Graves 1995) do not occur in this assemblage. In short, the Grisaille glass from Dundrennan probably dates to the 13th century, and possibly slightly earlier.

\subsection{Five windows}

The sherds represent the remains of at least five windows/panels, and possibly more, based on variations in thickness and decoration.

Window I A number of the sherds appear to derive from a single window of unknown size, up to $2-3 \mathrm{~mm}$ in thickness. This window was decorated with a series of circles/ovals outlined by two bands of red/ brown paint, defining a central area up to $10 \mathrm{~mm}$ in diameter with no decoration (illus 40, nos. 2-5). Within and outside the circles/ovals was the characteristic cross-hatching, and the occasional trefoil design, executed with a border of grisaille, with the trefoil itself possibly painted. Due to the presence of cross-hatching in the decoration, this window/panel may be dated to the 13 th century.

Window II A single sherd of glass with crosshatching and a larger trefoil (illus 40, no. 1) may have belonged to a separate window/panel, in that the glass is somewhat thicker $(4 \mathrm{~mm})$, and the design slightly different. Again, the sherd is indicative of 13th-century activity.

Window III A large number of the sherds display signs of the banding seen on the sherds with crosshatching, but with the cross-hatching itself being absent (illus 40, no. 6). These may represent a less ornamental window or panel, or may simply be derived from the less heavily decorated parts of the window.

Window IV Some of the sherds are painted in the usual grisaille manner, but in these examples the $\mathrm{red} / \mathrm{brown}$ bands are accompanied by a band of lighter, beige paint. The lighter paint is not apparent on the remaining sherds in the assemblage, and so it seems likely that these sherds are derived from a discrete window or panel.

Window V Some sherds display markedly less patina than the remainder of the assemblage. In addition, these sherds are much thinner, between $1 \mathrm{~mm}$ and 2 $\mathrm{mm}$ in thickness. None is painted, and it seems likely that these sherds derive from an unpainted, more modern (post-Reformation?) window. 


\section{Architectural fragments by Andrew Dunn}

In all, 412 separate architectural fragments were recovered and catalogued during the excavations (these include two in situ springers of the ribbed ceiling vault in room 5 and a grave slab re-used to cover the great drain). The fragments appear to derive exclusively from the area under excavation: that is, they represent the remains of buildings which have collapsed in situ, and which have since undergone robbing and further reduction. The majority of the fragments are the remnants of a system of quadripartite vaulting, the principal means by which the undercroft supported the floors above. These perhaps escaped robbing because of their irregular form, making them less attractive as building blocks in comparison to the more regular stones from the walls of the former structures. The relative frequency of all fragment types in the assemblage is shown in Table 1.

Table 1 Architectural fragments: frequency of different elements in the assemblage

\begin{tabular}{lc}
\hline Type & Freq. \\
\hline vault rib & 246 \\
door/window & 46 \\
quoins/'corner' elements & 22 \\
Springer & 11 \\
Column & 4 \\
string course & 4 \\
scarcement & 4 \\
buttress & 3 \\
drain elements & 2 \\
capitol & 1 \\
Arch & 1 \\
slab & 1 \\
garderobe & 1 \\
threshold & 1 \\
unknown & 65 \\
Total & 409 \\
\hline
\end{tabular}

\subsection{Masons' marks (illus 41)}

Some 226 of the fragments (55\%) bore masons' marks of one kind or another. Forty-three different types were recorded (although the most common mark is not, strictly speaking, a mason's mark). The relative frequency of each type is given in Table 2.

The marks are largely concentrated on fragments of ceiling vault ribbing (only three types are absent from ribbing) though, in this context, Type 1 could more accurately be described as a locating device rather than a true mason's mark. This appears on the tops or bottoms of the dressed stones forming the rib and indicated the correct position for the next stone in the construction sequence.

On some fragments more than one mark occurs. In most cases where two occur, one of the marks is of Type 1 (not a true masons' mark). However, in 18 cases (all vault ribs), marks of two other types (sometimes alongside a Type 1 mark) appear in conjunction. The most common mark in the pairings is Type 10 , perhaps representing a mason who finished or assembled the ribs, rather than one who worked them up from undressed blocks of quarry stone.

Table 2 Type and frequency of masons' marks (see illus 41)

\begin{tabular}{rrlrllll}
\hline No. & Freq. & No. & Freq. & No. & Freq. & No. & Freq. \\
\hline 1 & 193 & 12 & 2 & 23 & 3 & 34 & 10 \\
2 & 1 & 13 & 12 & 24 & 1 & 35 & 7 \\
3 & 1 & 14 & 1 & 25 & 1 & 36 & 1 \\
4 & 1 & 15 & 1 & 26 & 2 & 37 & 1 \\
5 & 14 & 16 & 1 & 27 & 3 & 38 & 1 \\
6 & 1 & 17 & 25 & 28 & 2 & 39 & 2 \\
7 & 1 & 18 & 2 & 29 & 1 & 40 & 1 \\
8 & 2 & 19 & 1 & 30 & 1 & 41 & 5 \\
9 & 5 & 20 & 1 & 31 & 9 & 42 & 4 \\
10 & 24 & 21 & 1 & 32 & 2 & 43 & 1 \\
11 & 1 & 22 & 15 & 33 & 1 & & \\
\hline
\end{tabular}



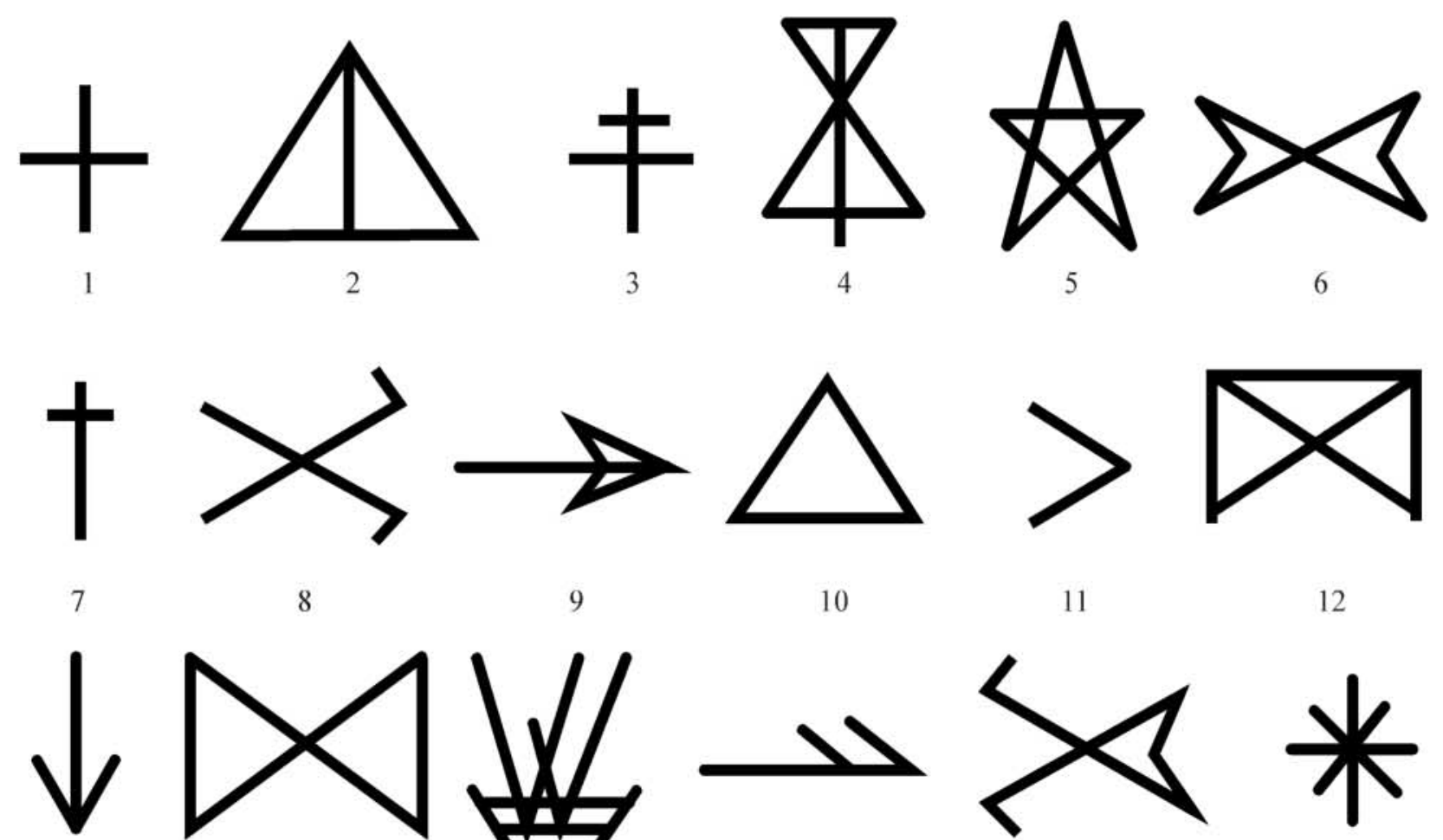

8

10

11

12

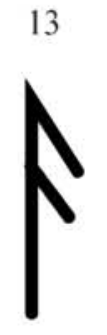

19

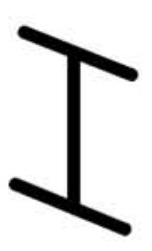

25

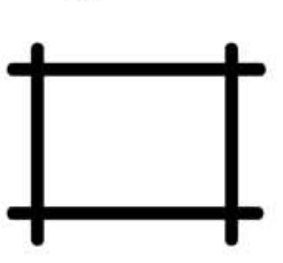

31

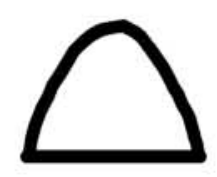

38

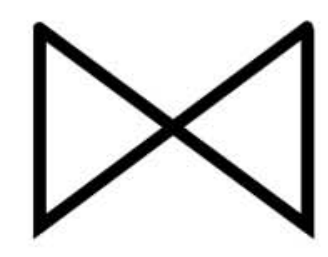

14
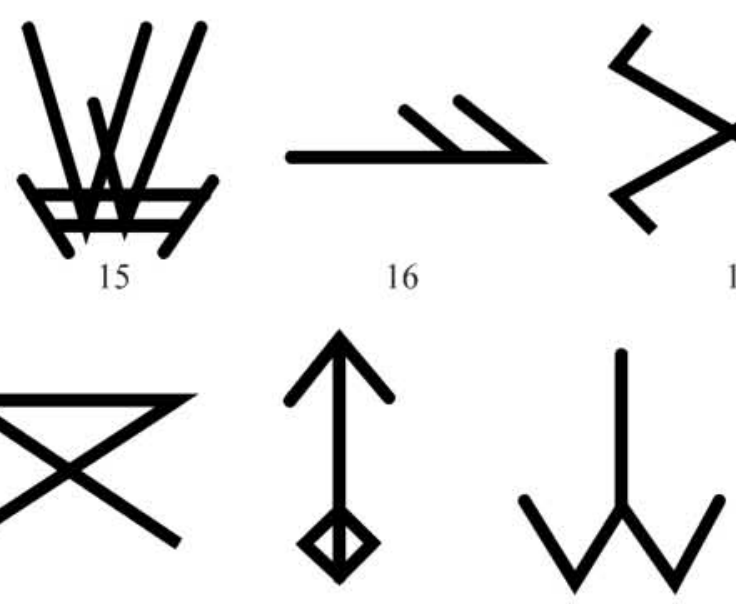

23

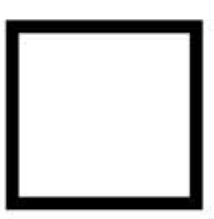

29

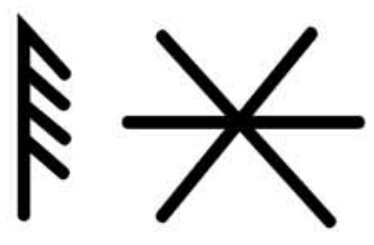

34

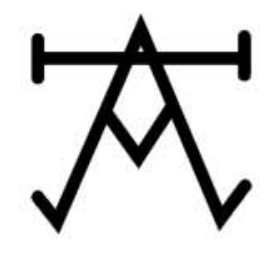

28

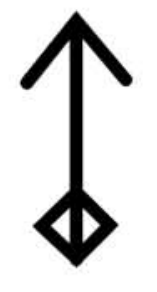

22
17

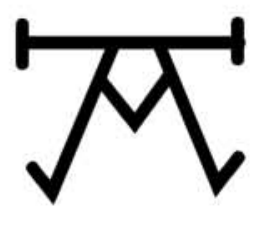

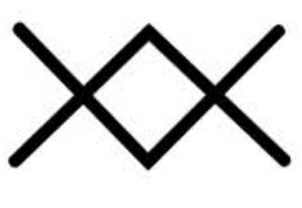

24

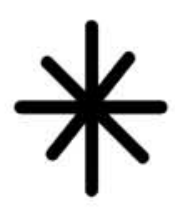

18

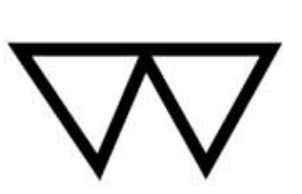

30
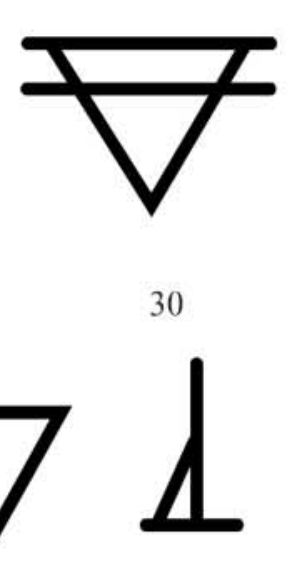

37 


\section{Mortar and plaster by Naomi Crowley}

\subsection{Methodology}

Samples of mortar were collected by hand from selected features on site and the majority of the bulk sediment samples also produced fragments of mortar. The assemblage was examined using a binocular microscope, at a magnification of $\times 20$, to identify the different types of mortar or plaster present. From this, samples were selected for further analysis by removal of the lime-based fraction. This involves dissolving a cleaned, dried and weighed sample in $10 \%$ hydrochloric acid to remove the lime binder. The percentage of lime to aggregate can be calculated and the size distribution and geological nature and source of the aggregate determined. The results allow comparison between different mortars and their distribution on site.

\subsection{Microscope examination}

Initial examination by microscope identified three types of mortar and a clay. These are described below. From these, five samples (renamed AOC/1-5) were chosen for further analysis.

Type 1 Samples of plaster from walls of room 4 (Period II). Plaster consisting of two layers. The backing layer varies in thickness from $13 \mathrm{~mm}$ to $15 \mathrm{~mm}$ and is a light pink-brown colour with frequent aggregate, moderate lime ball inclusions, occasional shell fragments, mica and voids. The surface layer is slightly uneven, varying from $<1 \mathrm{~mm}$ to $2 \mathrm{~mm}$ and consists of a white limewash. The backing mortar from each sample was selected for further analysis and assigned new sample numbers $\mathrm{AOC} / 3$ and $\mathrm{AOC} / 4$ respectively.

Type 2 Sample of rendering from blocking of archway (context 136, Period V), and other material, mostly from bulk samples. Off-white coloured mortar with frequent aggregate, occasionally up to $10 \mathrm{~mm}$, moderate voids, occasional shell fragments and lime ball inclusions. The sample from the blocking of the archway contains very occasional fine orange hairs.

Type 3 Hard greyish brown coloured mortar with frequent aggregate and occasional burnt coal. Possibly cementitious. From context 099, midden deposit, Period IV-V.

Type 4 Light orange coloured fine grained clay with impressions of fine organic matter, from room 6 (Period IV). This was selected for further analysis and assigned the sample number AOC 1.

\subsection{Analysis by removal of lime}

Samples AOC/2-5 all contain shell fragments in the aggregate. As shell dissolves in hydrochloric acid, the percentage in each sample was estimated before the sample was dissolved and this figure incorporated into the results.

AOC / 1 This Type 4 clay sample was dissolved in hydrochloric acid to determine if it was a clay mortar containing lime. There was no significant reaction and so it is concluded that the sample contained no lime.

AOC / 2-5 The analysis of these samples confirms the initial identification of the two mortar types. The grain size distribution graphs for $\mathrm{AOC} / 3$ \& 4 (both Type 1) showed a strong similarity. Both are a limerich plaster containing a fine aggregate. AOC/2 \& 5 (both Type 2) have similar size distribution curves, but are different to AOC/3 \& 4, with coarser aggregate. The aggregate in all the samples consists of grains of sandstone, schist and granite in the coarser fractions with mainly quartz, mica and other minerals degraded from the different rock types in the finer fractions. The geology suggests a local source and the presence of shell indicates that the aggregate is a beach sand.

\subsection{Discussion}

The examination of the mortar samples suggests that throughout the different phases of building the same source of local sand was used for the mortars and plasters. Type 1, a fairly fine plaster, was used in room 4 in Period II and covered with a white limewash. Fragments of this also occur in the fill of the construction trench for the blocking of the archway in that room in Period V (see 4.6.2 Room 4 $\& 6)$. The rendering used on the blocking of this archway in Period V (context 136) consists of a coarser whiter mortar, Type 2. Fragments from most of the bulk sediment samples, ranging in date from Period I to Period V, resemble this type. It is difficult to determine whether this apparent chronological spread is due to continuity in use of material sources through time or to complex processes of deposition and disturbance. A small cementitious Type 3 fragment from Period V, is probably 19 th $/ 20$ th-century in date. The Type 4 material, which is a clay rather than a clay lime mortar, derives from room 6 in Period IV (see 4.5.3 Room 6). 


\section{Plant remains by Dorothy Rankin}

\subsection{Methodology}

Forty-three sediment samples were processed using a system of flotation and wet-sieving, adapted from the Siraf system (Williams 1973). They ranged in size from 1 litre to 26 litres. The floating debris (flot) was collected in mesh sizes $0.3 \mathrm{~mm}$ and $1 \mathrm{~mm}$ and the non-floating residue (retent) was wet-sieved through a $1 \mathrm{~mm}$ mesh. Identifications of weed seeds and cereals were made using modern comparative material from the reference collection of AOC Archaeology Ltd. The nomenclature for wild species follows that of the Flora Europaea (Tutin et al 1964-80).

\subsection{Samples}

Thirty-eight samples produced plant remains, spanning the occupation, rebuilding and abandonment of the abbey. At least thirteen samples originated from the midden deposits and, except for three samples thought to relate to Periods I or IV/V, all of these derived from Period IV (see especially 4.7.1 Middens). Seven of the samples derived from fills of the great drain. These are mainly thought to belong to Periods IV and V, although there may be some reworking of these deposits. (4.7.2 Great drain fills). Indeed, the fills themselves appear to reflect a phase when the drain had fallen into disuse, having been allowed to silt up. The remaining samples derive mainly from floor deposits and most of these are linked to Period IV. The results are described below and summarised in Table 3.

\subsection{Results}

\subsubsection{Charred plant remains}

This component was dominated by cultivated plants or weed species associated with cereal production. Oats predominated, with lesser amounts of barley and wheat. No remains of chaff were recovered. The non-cereal element included segetal and ruderal species, together with those more commonly associated with aquatic environments, as well as moors and bogs.

\subsubsection{Uncharred plant remains}

Uncharred remains were recovered from 26 samples. There were no cereal testa or uncarbonised cereal grains. The remains were dominated by mud-loving species, and semi-aquatics. Nineteen samples contained such species, predominantly Ranunculus scleratus L. (celery-leaved crowfoot) and Callitriche sp. (water star-wort), of which seven samples produced a large quantity of remains.

Some of the species represented in the samples were of a very robust nature, such as seeds of raspberry and elderberry. Intriguingly, deposits of uncarbonised fig were recovered; their presence, in that fig is not a commonly growing species in Scotland, suggests that at least some of the assemblage of uncarbonised remains does represent monastic waste rather than later, intrusive material. However, although fig is not usually found as a modern contaminant, this possibility cannot be totally ruled out (Dickson \& Dickson 1996, 631).

\subsection{Discussion}

The composition of the charred plant assemblage through all phases of deposition reflects a striking consistency. Oats predominate throughout with lesser quantities of barley, wheat and weed seeds. This probably reflects the use of these cereals throughout the occupation of the site, with oats being the most popular in all periods. Indeed this shows very much the trend for the high medieval period in Scotland (Boyd 1988). Investigations at Perth, for instance, found that oats and barley were the most frequently recovered cereals there too (Robinson 1987).

Unfortunately it has not been possible to determine whether the crops at Dundrennan were locally grown. Certainly, the weed assemblage, indicating sandy acid soils, could have come from local fields. The chaff debris normally associated with cereal processing is absent (whereby heat is applied to the grain to remove enclosing lemmas and paleas) and this suggests an already fully processed crop. Furthermore, there is no evidence for bulk storage and drying of grain. Thus, these plant remains probably represent domestic refuse or the sweepings of kitchen hearths rather than the debris of crop processing.

The use of turf as a fuel is suggested by some carbonised weed seeds found in association with carbonised earthworm eggs, as the practice of using turf to bank fires was widespread in the medieval period (pers comm, J Miller).

Much of the uncarbonised material was recovered from deposits in the great drain or associated middens, including possible latrine waste. Although cereal bran can be an indicator of such deposits, cereal testa were absent in the present case. 
Table 3 Plant remains

\begin{tabular}{|c|c|c|c|c|c|c|}
\hline & & Phase & $\mathbf{I}$ & IV & IV/V & $\mathbf{V}$ \\
\hline \multicolumn{7}{|l|}{ Charred remains } \\
\hline Species/Genus & Common name & Plant part & & & & \\
\hline Cerealia indet & indet. cereal & caryopsis & & 17 & 2 & 4 \\
\hline Cerealia indet & indet. cereal & $\begin{array}{l}\text { vesicular } \\
\text { fragments }\end{array}$ & & $* * *$ & & * \\
\hline cf Cerealia indet & cf indet. cereal & caryopsis & $*$ & 2 & & $*$ \\
\hline Hordeum vulgare indet & barley & caryopsis & & 2 & 1 & \\
\hline $\begin{array}{l}\text { Hordeum vulgare indet } \\
\text { (asymmetrical) }\end{array}$ & six-row barley & carlopsis & & 2 & & \\
\hline $\begin{array}{l}\text { Hordeum vulgare hulled, } \\
\text { symmetrical }\end{array}$ & six-row hulled barley & caryopsis & & 1 & 1 & \\
\hline $\begin{array}{l}\text { Hordeum vulgare hulled, } \\
\text { asymmetrical }\end{array}$ & six-row hulled barley & caryopsis & & & 1 & \\
\hline $\begin{array}{l}\text { Hordeum vulgare naked, } \\
\text { symmetrical }\end{array}$ & six-row hulled barley & caryopsis & & 2 & & \\
\hline Avena sp & oat & caryopsis & 4 & $145(127)$ & 15 & 3 \\
\hline cf Avena sp & cf oat & caryopsis & 2 & 3 & 1 & $*$ \\
\hline Triticum cf aestivo-compactum & cf bread/club wheat & caryopsis & & 1 & & 1 \\
\hline Triticum sp & wheat & caryopsis & & 1 & & \\
\hline cf Triticum sp & cf wheat & caryopsis & & & & \\
\hline Hordeum/Triticum sp & barley/wheat & caryopsis & & 2 & & \\
\hline Secale/Triticum sp & rye/wheat & caryopsis & & 2 & & \\
\hline Corylus avellana $\mathrm{L}$ & hazel & shell & 1 & 6 & & \\
\hline cf Corylus avellana & cf hazel & bud & & & 1 & \\
\hline Rubus idaeus $\mathrm{L}$ & raspberry & achene & & 3 & & 1 \\
\hline Vitis vinifera $\mathrm{L}$ & common grape & pip & & & & \\
\hline Sambucus nigra / racemosa & elderberry & drupe & & 1 & & \\
\hline cf Ficus carica & cf common fig & pip & & 1 & & \\
\hline Euphorbia helioscopia L & sun spurge & seed & & & & 2 \\
\hline Chysanthemum segetum $\mathrm{L}$ & corn marigold & achene & 1 & 1 & & 3 \\
\hline Rumex acetosella agg & sheep's sorrel & nutlet & & 1 & & \\
\hline Scleranthus annuus L & annual knawel & seed & & 1 & & \\
\hline Brassica cf nigra & black mustard & seed & & 1 & & \\
\hline $\begin{array}{l}\text { Ranunculus repens / acris / } \\
\text { bulbosus }\end{array}$ & $\begin{array}{l}\text { creeping/meadow } \\
\text { buttercup }\end{array}$ & achene & 1 & & & \\
\hline Stellaria media (L) Vill & chickweed & seed & & & & \\
\hline $\begin{array}{l}\text { Polygonum persicaria/ } \\
\text { lapathifolium }\end{array}$ & $\begin{array}{l}\text { persicaria/pale } \\
\text { persicaria }\end{array}$ & nutlet & & & & \\
\hline Polygonum cf minus & bistort & nutlet & & & & \\
\hline Polygonum sp & bistolt & nutlet & & 1 & & \\
\hline Chenopodium album L & fat hen & seed & & 3 & & \\
\hline Atriplex/Chenopcdium sp & orache/goosefoot & seed & & 1 & & \\
\hline Rumex sp & dock & nutlet & & & & \\
\hline Polygonaceae indet & bistort & nutlet & & 1 & & \\
\hline Silene cf alba & white campion & seed & & 1 & & \\
\hline
\end{tabular}


Table 3 (cont.) Plant remains

\begin{tabular}{|c|c|c|c|c|c|c|}
\hline & & Phase & $\mathbf{I}$ & IV & IV/V & $\mathbf{V}$ \\
\hline Galium aparine $\mathrm{L}$ & cleavers & seed & & 1 & & \\
\hline Rumex longifolius/obtusifolius & dock & nutlet & & 1 & & \\
\hline Potentilla sp & cinquefoil & achene & & 1 & & \\
\hline Rosaceae indet & rose family & seed & & 1 & & \\
\hline Poa sp & meadow grass & caryopsis & & 1 & & \\
\hline Gramineae indet & grass family & caryopsis & & 3 & & 2 \\
\hline cf Gramineae indet & cf grass family & caryopsis & $*$ & & & \\
\hline Compositae indet & daisy family & achene & & 2 & 1 & \\
\hline cf Compositae indet & cf daisy family & achene & & 1 & & \\
\hline Vicia/Lathyrus / Pisum sp & vetch/tare/pea & seed & & 1 & & \\
\hline Leguminosae indet & pea family & seed & & 1 & & \\
\hline cf Leguminosae indet & cf pea family & seed & & 1 & & \\
\hline Calluna vulgaris / Erica sp & ling/heather & stem/leaflets & & $22(13)$ & & \\
\hline Calluna vulgaris (L) Hull & ling & bud & & 6 & & \\
\hline cf Calluna vulgaris / Erica sp & ling/heather & misc. parts & & & & \\
\hline Carex $\mathrm{sp}-$ biconvex & sedge & nutlet & & 2 & 1 & 1 \\
\hline Carex $\mathrm{sp}$ - trigonous & sedge & nutlet & & 13 & 1 & 2 \\
\hline Cyperaceae indet & sedge & inard & & 6 & & \\
\hline Cyperaceae indet & sedge & nutlet & & 1 & & \\
\hline Menyanthes trifoliata $\mathrm{L}$ & bogbean & seed & & 1 & & \\
\hline cf Eleocharis sp & cf spike rush & seed & 1 & & & \\
\hline Juncaceae indet & rush & seed & & 1 & & \\
\hline Indeterminate & indeterminate & bud & & 6 & $* *$ & \\
\hline Indeterminate & indeterminate & seed/inard & 2 & 36 & 3 & 4 \\
\hline Indeterminate & indeterminate & misc parts & & 11 & & 3 \\
\hline \multicolumn{7}{|l|}{ Uncharred remains } \\
\hline Species/Genus & Common name & Plant part & & & & \\
\hline Rubus idaeus $L$ & raspberry & achene & & & 1 & \\
\hline Urtica dioica $\mathrm{L}$ & common nettle & seed & 11 & $154(28)$ & & \\
\hline Urtica $\mathrm{sp}$ & nettle & seed & & 1 & 1 & \\
\hline cf Urtica $\mathrm{sp}$ & cf nettle & seed & 1 & 1 & & \\
\hline Ranunculus scleratus L & celery-leaved crowfoot & achene & 149 & $5894(1124)$ & 2 & 2 \\
\hline Callitriche sp & water star-wort & nutlet & 6 & 136 & & \\
\hline Sonchus asper & prickly sowthistle & achene & & 1 & 1 & \\
\hline Sambucus nigra / racemosa & elderberry & drupe & & $52(16)$ & & 2 \\
\hline Potentilla $\mathrm{sp}$ & cinquefoil & achene & & $75(15)$ & & \\
\hline cf Potentilla sp & cf cinquefoil & achene & & $10(1)$ & & \\
\hline Rosaceae indet & rose family & achene & & 2 & & \\
\hline Indeterminate & indeterminate & seed & 3 & $28(4)$ & & \\
\hline Ficus carica & fig & pip & 1 & $20(2)$ & & \\
\hline cf Ficus carica & $\mathrm{cf}$, tig & pip & & $50(5)$ & & \\
\hline $\begin{array}{l}\text { Polygonum persicaria / } \\
\text { lapathifolium }\end{array}$ & $\begin{array}{l}\text { persicaria/pale } \\
\text { persicaria }\end{array}$ & nutlet & & $20(2)$ & 1 & \\
\hline
\end{tabular}


Table 3 (cont.) Plant remains

\begin{tabular}{|c|c|c|c|c|c|c|}
\hline & & Phase & $\mathbf{I}$ & IV & IV/V & $\mathbf{V}$ \\
\hline Polygonum sp & perslcarla & nutlet & & 3 & & \\
\hline Chenopodium album & fat hen & seed & & $20(2)$ & 1 & \\
\hline Chenopodium/Atriplex sp & goosefoot/orache & seed & & $15(3)$ & & \\
\hline Atriplex sp & orache & seed & & $22(4)$ & & \\
\hline Rumex sp & dock & nutlet & & $70(7)$ & & \\
\hline Umbelliferae indet & carrot family & achene & & 1 & & \\
\hline Caryophyllaceae indet & & & & $26(14)$ & & \\
\hline $\begin{array}{l}\text { cf Leguminosae/ } \\
\text { Cruciferae indet }\end{array}$ & pea/mustard family & seed & & 3 & 1 & \\
\hline Carex sp & sedge & nutlet & & & & \\
\hline Bryophyta & moss & fruiting capsule & & $15(6)$ & & \\
\hline
\end{tabular}

Notes to Table 3

1. Asterisks denote relative quantity using a DAFOR scale: * rare, ** occasional, *** frequent, **** abundant, ***** dominant.

2. One large sample (context 193) was riddled, using a standard sampling riddle, into various fractions of its original size. For totals including seeds from this sample, in Period IV, numbers in brackets represent the actual number of seeds recovered while unbracketed numbers represent estimates of totals which would have been recovered using $100 \%$ of all samples.

However, this does not necessarily mean that the material was not faecal in origin. In general, the recovery techniques were more appropriate to unwaterlogged deposits and the conditions for preservation were far from ideal. Cereal bran is very delicate and does not always survive, even in wet or anaerobic conditions. Thus some of the deposits containing uncarbonised edible plant remains - such as raspberry, elderberry and fig - may after all represent human faeces in the great drain or in reworked garderobe deposits.

The similarity of the deposits of the great drain to those elsewhere, predominantly the midden complex, even in their inclusion of the uncharred remains of Ranunculus scleratus L., may indicate that the latter sediments originated from the drain itself. That is, they represent silts removed from a clogged drainage system. This would also mean that the midden deposits had been reworked in antiquity, rather than found in a primary, undisturbed state.

There are doubts as to the age of some of the uncharred assemblage. Part of the assemblage may be ancient and waterlogged (Holden 1995). Many of the weed seeds represented are those with fairly robust seed coats such as elderberry, raspberry and fig (and as suggested above some of these may be inclusions in faecal deposits). These durable seeds could have survived for some time without waterlogging, mineralisation or charring. Should this be the case, their presence probably reflects their persistence in the primary archaeological sediments, rather than contamination either by redeposition or by biological activity. In contrast, the presence of semi-aquatic species such as Callitriche sp. and Ranunculus scleratus L. in great numbers, particularly from midden deposits, could represent secondary inclusions introduced by earthworm activity, animal burrows and root systems. Alternatively, these semiaquatic species could have been deposited into the drainage channel during its use. These plants grow in the muddy edges of streams and ponds and the seeds could have been deposited into the stream channel which flushed through the great drain, collecting in the sediments which formed in this channel while it was in use and, afterwards, as it began to silt up completely. The presence of iron salts on some of these seeds probably results from the fluctuating local water table, indicating episodic waterlogging. 


\section{Mammals and birds by Tanya O'Sullivan}

\subsection{Methodology}

Bone material was recovered both by hand on site, and from sieved samples. Bones were identified using the reference collection at AOC Archaeology Ltd and National Museums of Scotland. Bone measurements and age determination followed standard guidelines (von den Dreisch 1976; Silver 1979).

\subsection{Large mammals}

The majority of large mammal bones were recovered from contexts attributed to Periods IV and V, with a smaller concentration from Period I. Two sheep long bone fragments were the only animal remains recovered from Period III contexts, and no bones from Period II were present in the assemblage. The bones were in good condition, although fragmented and broken to such a degree that biometrical and ageing data was limited. All of the bones recovered are listed in Table 4.

Period I The bone bearing contexts from Period I did not represent a homogenous group. The samples were from the floor of Room 5 , the fill of the great drain, and masonry associated with the drain. Each context yielded a minimum of one cow and one sheep.

Period IV Animal bones were recovered from 27 contexts in Period IV. However, most of these yielded just a few fragments of either cattle or sheep bone. A minimum of two cows and two sheep were represented from the drain fills, one cow and one sheep from the midden deposits, and two sheep and one cow from Period IV floor deposits.

Period $V$ Twenty contexts yielded animal bone in Period V. Again no more than a minimum of one or two cattle or sheep were present, including a complete cow skeleton from the upper fill of the drain.

\subsubsection{Livestock husbandry}

Although the Dundrennan sample as a whole was substantial, it consisted of small, spatially distinct groups of broken bone. Pig remains, apart from a tooth, are absent from the assemblage. Pigs do not appear to have played a large part in the economy of Cistercian communities in Scotland. Houses of other orders - such as the Observantine friars at Jedburgh appear to have eaten pork in small quantities (Groves forthcoming). There are a number of reasons why one would not expect to find pig at Dundrennan. In the early days the Cistercians' strict diet forbade the eating of meat from four legged beasts except for inmates of the infirmary (Cook 1961, 153). This was relaxed in later years and consumption of meat was allowed on Sundays, Tuesdays and Thursdays. A survey of the percentage of fragment distribution on Scottish castle sites (McCormick 1996; McCormick 1997; and McCormick forthcoming) also reveals small numbers of pig. The absence of oak forest is generally thought to be the reason for the lack of pig remains on these sites, as pigs need oak and beech mast to forage successfully. Similarly, the practice of clearing woodland for agricultural purposes would have depleted the availability of woods for pannage in the vicinity of the monasteries.

Unlike pig, both cattle and sheep had uses other than as meat animals. In fact, cattle were mainly kept for draught purposes and the chief function of the cow was to breed plough oxen (Symon 1959, 57). Sheep were kept largely for their milk and wool, as well for meat. The intensive breeding of stock and production of wool were likely activities at Dundrennan, in keeping with the Cistercian tradition as observed at Melrose, Newbattle, Kelso and Coupar Angus. The Cistercians at Melrose derived much of their revenue from the pasturing of stock and, for example, in 1180 were given the right to build a vaccaria for 100 cows in Threipwood; while Newbattle Abbey had the right of pasturage for 1000 sheep and 60 cattle; and Kelso Abbey had 80 cows at Witelaw (ibid). The bones from Dundrennan, although not adding much to the picture, do not imply any great divergence from this pattern. However, where the Minimum Number of Individuals (MNI) could be ascertained it would appear that sheep outnumbered cattle by two to one in some contexts and appeared in equal numbers in others. Some data on bone fusion for both cattle and sheep could be gleaned and is given by Table 5 .

\subsubsection{Butchery}

All skeletal elements were represented in the sample, indicating that animals were brought in on the hoof for slaughter rather than as pre-processed meat coming into the abbey in the form of jointed carcasses. The bone distribution does not provide evidence for specialised butchery dumps. The only notable feature of the butchery evidence was that not only did the bones display all the signs of both primary and secondary butchery but there was evidence that they were further cut after the meat was consumed, presumably to extract marrow or make broth. One split cattle proximal radius from Period I shows cut marks on its inner surface. Marrow was an 
Table 4 Mammal bones

\begin{tabular}{|c|c|c|c|c|c|c|c|c|c|}
\hline Species & Element & Break & Age & Butch. & Taph. & $\mathbf{R F}$ & LBF & $\mathbf{U} / \mathbf{I}$ & Comments \\
\hline \multicolumn{10}{|l|}{ Period 1} \\
\hline cattle & $c d v$ & 1 & & & & & & & \\
\hline cattle & cev & 1 & & & & & & & \\
\hline cattle & thv & 1 & & & & & & & \\
\hline cattle & femur & $3 p$ & & & & & & & \\
\hline cattle & scapula & $3 p$ & $\mathrm{f}$ & & & & & & \\
\hline cattle & pelvis & 1 & & $\operatorname{chp}$ & & & & & \\
\hline cattle & pelvis & 1 & & & & 10 & & & \\
\hline cattle & femur & $1 d$ & & & & & & & \\
\hline cattle & femur & $1 d$ & & & & & & & \\
\hline cattle & humerus & $3 p$ & & & & & & & \\
\hline cattle & femur & $3 p$ & & & & & & & \\
\hline cattle & humerus & $3 d$ & & & & & & & \\
\hline cattle & & & & & & & & & $\mathrm{r}$ all unid \\
\hline cattle & ph1 & & & & & & & & $\mathrm{r}$ \\
\hline cattle & radius & $2 p$ & & & & 2 & & 16 & \\
\hline cattle & $\mathrm{mc}$ & & & & & & & & \\
\hline cattle & radius & $2 p$ & & $\operatorname{chp}$ & & 12 & & & inner surface \\
\hline cattle & radius & $2 \mathrm{~d}$ & & & & & & & \\
\hline cattle & ph1 & & & & & & & & \\
\hline cattle & $\mathrm{mc}$ & & & & & & & & \\
\hline cattle & $\mathrm{mt}$ & $2 p$ & & $\operatorname{chp}$ & & & & & \\
\hline cattle & $\mathrm{mt}$ & $2 \mathrm{~d}$ & & & & & & & \\
\hline cattle & $\mathrm{ph} 2$ & & & & & & & & \\
\hline cattle & ph3 & & & & & & & & \\
\hline cattle & cev & & & & & & & & \\
\hline cattle & ulna & & & $\operatorname{chp}$ & & & & & \\
\hline cattle & calcaneus & & & & & & & & \\
\hline cattle & astragalus & & & & & 1 & 2 & & \\
\hline cattle & $\mathrm{mt}$ & $1 p$ & & & & & & & $\begin{array}{l}2 \text { frgs burnt } \\
\text { bn }\end{array}$ \\
\hline sheep & & & & & & 5 & & & \\
\hline sheep & humerus & $3 \mathrm{~d}$ & & & & & & & \\
\hline sheep & teeth & 1 & & & & & & & \\
\hline sheep & & & & & & & & & $\mathrm{r}$ all unid \\
\hline sheep & scapula & & & & & & & & \\
\hline sheep & tooth & & & & & & & & \\
\hline sheep & tibia & $2 p$ & & & & & & & \\
\hline sheep & $\mathrm{mt}$ & $2 p$ & & & & & & & \\
\hline sheep & tibia & $8 \mathrm{~s}$ & & & & & & & \\
\hline sheep & radius & $8 s$ & & & & & & & \\
\hline sheep & radius & $8 \mathrm{~s}$ & & & & & & & \\
\hline
\end{tabular}


Table 4 (cont.) Mammal bones

\begin{tabular}{|c|c|c|c|c|c|c|c|c|c|}
\hline Species & Element & Break & Age & Butch. & Taph. & $\mathbf{R F}$ & LBF & $\mathbf{U} / \mathbf{I}$ & Comments \\
\hline sheep & $\mathrm{mc}$ & $8 \mathrm{~s}$ & & & & & & & \\
\hline sheep & $\mathrm{mc}$ & $8 \mathrm{~s}$ & & & & & & & \\
\hline sheep & tibia & $2 d$ & & & & & & & \\
\hline sheep & humerus & $2 \mathrm{~d}$ & & & & & & & \\
\hline sheep & mandible (2) & & & & & & & & \\
\hline sheep & teeth (4) & & & & & & & & \\
\hline sheep & calcaneus & & & $\operatorname{chp}$ & & & & & \\
\hline sheep & ulna & & & & & & & & \\
\hline sheep & humerus & $2 \mathrm{~d}$ & & & $\mathrm{~g}$ & & & & \\
\hline sheep & humerus & $2 p$ & & & & & & & \\
\hline sheep & pelvis & & & & & & & & \\
\hline sheep & scapula (12) & & & & & & & & \\
\hline sheep & mandible & & & & & 4 & & & $\begin{array}{l}4 \text { teeth, } \\
\text { malfor. }\end{array}$ \\
\hline \multicolumn{10}{|l|}{ Period II } \\
\hline sheep & cev & & & & & & & & \\
\hline sheep & teeth (12) & & & & & & & 6 & \\
\hline sheep & & & & & & & & & $\mathrm{r}$ all unid \\
\hline \multicolumn{10}{|c|}{ Period IV } \\
\hline cattle & astragalus & & & & & & & & \\
\hline cattle & $\mathrm{mt}$. & $2 \mathrm{~d}$ & & & & & 3 & & \\
\hline cattle & ulna & $2 p$ & & & & & & & \\
\hline cattle & $\mathrm{mt}$. & $2 p$ & & & & & & & \\
\hline cattle & humerus & $2 \mathrm{~d}$ & & & & & & & \\
\hline cattle & tooth & & & & & & & & \\
\hline cattle & & & & & & 1 & & & \\
\hline cattle & & & & & & 1 & & & \\
\hline cattle & vert & & $\mathrm{u}$ & & & & & & $\mathrm{r}$ \\
\hline \multicolumn{10}{|l|}{ cattle } \\
\hline cattle & & & & & & 2 & & & $\mathrm{r}$ all unid \\
\hline cattle & ph3 & & & & & & & & \\
\hline cattle & skull & & & & & 7 & 8 & 5 & \\
\hline cattle & tibia & $2 \mathrm{~d}$ & & & & & & & \\
\hline cattle & ulna & & $\mathrm{u}$ & & & 3 & & & \\
\hline cattle & ulna & & & & & & & & \\
\hline cattle & skull (12) & & & & & & & & \\
\hline cattle & pelvis & & & & & & & & \\
\hline cattle & scapula & & & & & & & & \\
\hline cattle & radius & $3 d$ & & & & 3 & 2 & & \\
\hline cattle & pelvis (3) & & & $\operatorname{chp}$ & & & & & \\
\hline cattle & $\mathrm{mt}$ & $2 p$ & & & & & & & \\
\hline cattle & ph (3) & & & & & & & & \\
\hline
\end{tabular}


Table 4 (cont.) Mammal bones

\begin{tabular}{|c|c|c|c|c|c|c|c|c|c|}
\hline Species & Element & Break & Age & Butch. & Taph. & $\mathbf{R F}$ & LBF & $\mathbf{U} / \mathbf{I}$ & Comments \\
\hline cattle & $\mathrm{mt}$ & $2 \mathrm{~d}$ & & & & & & & \\
\hline cattle & tibia & $2 d$ & $\mathrm{u}$ & & & & & & \\
\hline cattle & femur & $2 d$ & & & & & & & \\
\hline cattle & femur & $2 p$ & & & & 12 & 7 & 19 & \\
\hline cattle & ph3 & & & & & & & & \\
\hline cattle & $\mathrm{mc}$ & $2 \mathrm{~d}$ & & & & & & & \\
\hline cattle & $\mathrm{mc}$ & $2 p$ & & & & & & & \\
\hline cattle & thv & & & & & & & & \\
\hline cattle & & & & & & 5 & & & $r$ \\
\hline cattle & carpal (2) & & & & & & & & $\mathrm{r}$ \\
\hline cattle & & & & & & 6 & 10 & & \\
\hline cattle & & & & & & 1 & & & $\mathrm{r}$ \\
\hline cattle & lbv & & & & & 7 & 6 & & \\
\hline cattle & scapula & & $\mathrm{u}$ & & & & & & \\
\hline cattle & $c d v$ & & & & & & & & \\
\hline cattle & astragalus & & & & & & & 100 & $\mathrm{r}$ \\
\hline cattle & ph1 & & & & & & & & $\mathrm{r}$ \\
\hline cattle & ph2 & & & & & & & & $\mathrm{r}$ \\
\hline cattle & ph3 & & & & & & & & $\mathrm{r}$ \\
\hline cattle & scapula (2) & & & & & & & & $\mathrm{r}$ \\
\hline cattle & mandible (2) & & & & & & & & $\mathrm{r}$ \\
\hline cattle & calcaneus & & & & & & & & $\mathrm{r}$ \\
\hline cattle & ph2 & & & & & 1 & & & \\
\hline cattle & ph1 & 1 & & & & & & & \\
\hline cattle & ph2 & & & & & & & & \\
\hline cattle & tibia & $1 \mathrm{~s}$ & & & & & & & \\
\hline cattle & ph1 (2) & & & & & & & & \\
\hline cattle & tibia & $2 \mathrm{~s}$ & & & & & & & \\
\hline cattle & $\mathrm{mc}$ & $2 \mathrm{~s}$ & & & & & & & \\
\hline cattle & pelvis & & & & & & & & \\
\hline cattle & $\mathrm{mt}$ & $2 p$ & & & & & & & \\
\hline cattle & scapula (2) & & & & & & & & \\
\hline cattle & astragalus & & & & & & & & \\
\hline cattle & tibia & $2 d$ & & & & & & & $r$ \\
\hline cattle & pelvis & & & & & & & & $\mathrm{r}$ \\
\hline cattle & ph1 & & & & & 4 & & & \\
\hline cattle & $\mathrm{ph} 2$ & & & & & & & & \\
\hline cattle & & & & & & & & & $\mathrm{r}$ all unid \\
\hline cattle & tibia & $2 \mathrm{~d}$ & & & & & & & \\
\hline cattle & $\mathrm{mc}$ & $2 \mathrm{p}$ & & & & & & 6 & \\
\hline cattle & humerus & $2 \mathrm{~d}$ & & $\operatorname{chp}$ & & & & & \\
\hline cattle & femur & $3 p$ & & & & 3 & & & \\
\hline
\end{tabular}


Table 4 (cont.) Mammal bones

\begin{tabular}{|c|c|c|c|c|c|c|c|c|c|}
\hline Species & Element & Break & Age & Butch. & Taph. & $\mathbf{R F}$ & LBF & $\mathbf{U} / \mathbf{I}$ & Comments \\
\hline cattle & & & & & & & & & $\mathrm{r}$ all unid \\
\hline cattle & $\operatorname{cev}(2)$ & & & & & & & & \\
\hline cattle & femur & $2 \mathrm{~d}$ & $\mathrm{u}$ & & & & & & \\
\hline cattle & scapula (2) & & & $\operatorname{chp}$ & & & & & \\
\hline cattle & ulna & & & $\operatorname{chp}$ & g & & & & \\
\hline cattle & humerus & $2 d$ & & & & & & & \\
\hline cattle & cev & & & & & & & & \\
\hline cattle & astragalus & & & $\operatorname{chp}$ & & & & & \\
\hline cattle & thv & & & & & & 1 & 13 & \\
\hline cattle & skull (3) & & & & & & & & \\
\hline cattle & $\mathrm{cdv}$ & & $\mathrm{u}$ & & & 36 & 4 & 17 & \\
\hline cattle & ph2 & & & & & & & & \\
\hline cattle & skull & & & & & & & & \\
\hline cattle & femur & $3 d$ & & & & 10 & 2 & & \\
\hline cattle & tibia & $1 \mathrm{p}$ & & & & & & & \\
\hline cattle & pelvis & 1 & & & & & & & \\
\hline cattle & ph1 & & & & & & & & \\
\hline cattle & thv & & & & & & & & \\
\hline cattle & pelvis & & & & & & & & \\
\hline cattle & & & & & & & 2 & & $\mathrm{r}$ all unid \\
\hline cattle & humerus & $2 p$ & & & & 16 & & & \\
\hline cattle & astragalus & & & & & & & & \\
\hline cattle & scapula & & & & & & & & $\mathrm{r}$ \\
\hline cattle & vert (2) & & & & & & & & $\mathrm{r}$ \\
\hline cattle & $\mathrm{mt}$ & $3 d$ & & & & & & & \\
\hline cattle & $\mathrm{mt}$ & $3 p$ & & & & & & & \\
\hline cattle & $\mathrm{mt}$ & $3 p$ & up & & & & & 4 & \\
\hline cattle & teeth & & & & & & & & \\
\hline cattle & & & & & & & & & $\mathrm{r}$ all unid \\
\hline $\operatorname{dog}$ & tooth & & & & & & & & $\mathrm{r}$ \\
\hline hare & humerus & $8 d$ & & & & & & & \\
\hline sheep & pelvis & & & & & 2 & & & \\
\hline sheep & tooth & & & & & & & 5 & \\
\hline sheep & & & & & & & & & r unid. \\
\hline sheep & ph2 & & & & & & & 19 & \\
\hline sheep & & & & & & 2 & & & \\
\hline sheep & humerus & $2 d$ & & & & & 2 & & \\
\hline sheep & mandible (2) & & & & & 18 & & 13 & m3 unerupted \\
\hline sheep & femur & $2 p$ & & & & & & & \\
\hline sheep & cev & 1 & & & & & 1 & 50 & \\
\hline sheep & calcaneus & & & & & & & & $\mathrm{r}$ \\
\hline sheep & humerus & $2 \mathrm{~d}$ & & & & & & & \\
\hline
\end{tabular}


Table 4 (cont.) Mammal bones

\begin{tabular}{|c|c|c|c|c|c|c|c|c|c|}
\hline Species & Element & Break & Age & Butch. & Taph. & $\mathbf{R F}$ & LBF & $\mathbf{U} / \mathbf{I}$ & Comments \\
\hline sheep & skull & & & & & & & & \\
\hline sheep & carpal & & & & & & & & \\
\hline sheep & pelvis & & & & & & & & \\
\hline sheep & pelvis & & & & & & 11 & & $\mathrm{r}$ \\
\hline sheep & pelvis & & & & & & & & $r$ \\
\hline sheep & tibia & $2 p$ & & & & & & & $r$ \\
\hline sheep & tooth & & & & & & & & \\
\hline sheep & tibia & $2 d$ & $\mathrm{u}$ & & & & & & \\
\hline sheep & tibia & $2 d$ & $f$ & $\operatorname{chp}$ & & & & & \\
\hline sheep & femur & $2 p$ & & & & & & & \\
\hline sheep & tibia & $2 p$ & & & & & & & \\
\hline sheep & mc. & $2 d$ & & & & & & & \\
\hline sheep & mc. & $2 p$ & & & & & & & \\
\hline sheep & mandible & & & & & & & & \\
\hline sheep & tibia & $1 d$ & & & & & & & \\
\hline sheep & tibia & $3 d$ & & & & & & & \\
\hline sheep & pelvis & & & & & & & & \\
\hline sheep & tooth & & & & & 7 & & & \\
\hline sheep & tibia & $3 p$ & & & & & & & \\
\hline sheep & radius & $3 d$ & $\mathrm{u}$ & & & & & & \\
\hline sheep & humerus & $3 d$ & & & & & & & \\
\hline sheep & humerus & $2 d$ & & & & & & & \\
\hline 0sheep & mandible (2) & & & & & & & & \\
\hline sheep & radius & $2 p$ & & & & & & & \\
\hline sheep & scapula (6) & & & $\operatorname{chp}$ & & & & & \\
\hline sheep & ulna & & & & & & & & \\
\hline sheep & pelvis (2) & & & & & & & & \\
\hline sheep & humerus & $3 d$ & $\mathrm{f}$ & & & & & & \\
\hline sheep & humerus & $2 p$ & & & & 10 & & & \\
\hline sheep & vert & & & & & & & & \\
\hline sheep & radius & $8 \mathrm{~s}$ & & & & 8 & 3 & & \\
\hline sheep & radius & $3 d$ & & & & & & & \\
\hline sheep & tibia & $8 \mathrm{~s}$ & & & & & & & \\
\hline sheep & pelvis & & & & & & & & \\
\hline sheep & teeth (3) & & & & & 2 & & & \\
\hline \multicolumn{10}{|l|}{ sheep } \\
\hline sheep & & & & & & & & & $\mathrm{r}$ all unid \\
\hline sheep & scapula & & & & & & & & $\mathrm{r}$ \\
\hline sheep & skull & & & & & & & & $\mathrm{r}$ \\
\hline sheep & teeth (6) & & & & & & & & $\mathrm{r}$ \\
\hline sheep & humerus & $2 d$ & & & & 4 & & & $\mathrm{r}$ \\
\hline sheep & tibia & $2 p$ & & & & & & & $\mathrm{r}$ \\
\hline
\end{tabular}


Table 4 (cont.) Mammal bones

\begin{tabular}{|c|c|c|c|c|c|c|c|c|c|}
\hline Species & Element & Break & Age & Butch. & Taph. & $\mathbf{R F}$ & LBF & $\mathbf{U} / \mathbf{I}$ & Comments \\
\hline sheep & mandible & & & & & & & & $\mathrm{r}$ \\
\hline sheep & vert & & & & & & & & $\mathrm{r}$ \\
\hline sheep & scapula & & & & & 7 & 8 & & $\mathrm{r}$ \\
\hline sheep & mandible (2) & & & & & & & & $\mathrm{r}$ \\
\hline sheep & tibia & $2 p$ & & & & & & & $\mathrm{r}$ \\
\hline sheep & teeth (10) & & & & & & & & $\mathrm{r}$ \\
\hline sheep & astragalus & & & & & & & & $\mathrm{r}$ \\
\hline sheep & teeth (14) & & & & & & & & $\mathrm{r}$ \\
\hline sheep & mandible & & & & & & & & $\mathrm{r}$ \\
\hline sheep & radius & $2 p$ & & & & 7 & & 100 & $\mathrm{r}$ \\
\hline sheep & $\mathrm{mc}$ & $1 \mathrm{~s}$ & & & & & & & \\
\hline sheep & radius & $9 d$ & & & & & & & \\
\hline sheep & humerus & $3 d$ & & & & & & & \\
\hline sheep & tibia & $8 s$ & & & & & & & \\
\hline sheep & humerus & $2 \mathrm{~d}$ & & & & & & & \\
\hline sheep & teeth $(6)$ & & & & & & & & \\
\hline sheep & tibia & $8 s$ & & & & & & 20 & \\
\hline sheep & femur & $3 d$ & & & & & & & \\
\hline sheep & $\mathrm{mc}$ & $8 s$ & & & & & & & \\
\hline sheep & ulna & & & & & & & & $\mathrm{r}$ \\
\hline sheep & pelvis (4) & & & & & & & & $\mathrm{r}$ \\
\hline sheep & mandible & & & & & & & & $\mathrm{r}$ \\
\hline sheep & ph2 & & & & & & & & \\
\hline sheep & tibia & $2 p$ & & & & & & & \\
\hline sheep & & & & & & & & & $r$ unid \\
\hline sheep & ph2 & & & & & & & & \\
\hline sheep & pelvis (2) & & & & & & 1 & 20 & \\
\hline tblsheep & $\mathrm{mt}$ & 8 & & & & & & & \\
\hline sheep & teeth $(6)$ & & & & & & & & \\
\hline sheep & humerus & $2 p$ & & & & & & & \\
\hline sheep & & & & & & 1 & & & $r$ unid \\
\hline sheep & tibia & $2 d$ & & & & & & & \\
\hline sheep & $\mathrm{mc}$ & $2 p$ & & & & & & & \\
\hline sheep & $\mathrm{mc}$ & $2 \mathrm{~d}$ & & & & & & & \\
\hline sheep & thv & & & & & & & & \\
\hline sheep & scapula & & & & & & & 3 & \\
\hline sheep & pelvis & & & & & & & & $\mathrm{r}$ \\
\hline sheep & humerus & $2 \mathrm{~d}$ & & & $\mathrm{~g}$ & & & & \\
\hline sheep & radius & $2 d$ & & & & & & & \\
\hline sheep & $\mathrm{mc}$ & $2 p$ & & & & 1 & & 6 & \\
\hline sheep & $\mathrm{mc}$ & $2 \mathrm{~d}$ & & & & & & & \\
\hline sheep & tibia & $2 p$ & & & & & & & \\
\hline
\end{tabular}


Table 4 (cont.) Mammal bones

\begin{tabular}{|c|c|c|c|c|c|c|c|c|c|}
\hline Species & Element & Break & Age & Butch. & Taph. & $\mathbf{R F}$ & LBF & $\mathbf{U} / \mathbf{I}$ & Comments \\
\hline sheep & tibia & $2 d$ & & & & & & & \\
\hline sheep & tibia & $2 \mathrm{~d}$ & & & & & & & \\
\hline sheep & tibia & $2 p$ & $\mathrm{u}$ & & & & & & \\
\hline sheep & calc & & & & & & & & r num unid \\
\hline sheep & pelvis & & & & & & & & \\
\hline sheep & tibia & $3 p$ & & & & & & 2 & \\
\hline sheep & tibia & $3 d$ & & & & & & & \\
\hline sheep & tibia & $3 d$ & & & & & & & \\
\hline sheep & tibia & $3 d$ & & & & & & & \\
\hline sheep & tibia & & & & & 6 & & & $\mathrm{r}$ \\
\hline sheep & pelvis (2) & & & & & & & & \\
\hline sheep & mandible & & & & & & & & m2 unerrup \\
\hline sheep & mand (2) & & & & & & & & \\
\hline sheep & cev & & & & & & & & \\
\hline sheep & scapula (5) & & & & & & & & \\
\hline sheep & ulna & 8 & & & & & & & \\
\hline sheep & ulna & $2 p$ & $\mathrm{f}$ & & & & & & \\
\hline sheep & calcaneus & & & & & & & & \\
\hline sheep & skull (2) & & & & & & & & \\
\hline sheep & atlas & & & & & & & & \\
\hline sheep & radius & $2 d$ & & & & & & & \\
\hline sheep & radius & $2 p$ & $\mathrm{f}$ & & & & & & \\
\hline sheep & radius & $2 d$ & $\mathrm{f}$ & & & & & & \\
\hline sheep & radius & $2 p$ & $\mathrm{u}$ & & & & & & \\
\hline sheep & humerus & $2 p$ & $\mathrm{u}$ & & & 18 & & & \\
\hline sheep & humerus & $2 d$ & & & & & & & \\
\hline sheep & humerus & $2 d$ & & & & & & & \\
\hline sheep & humerus & $2 d$ & & & & & & & \\
\hline sheep & cev & & & & & & & & \\
\hline sheep & skull (2) & & & & & & & & \\
\hline sheep & atlas (2) & & & & & & & & \\
\hline sheep & astragalus & & & $\operatorname{chp}$ & & & & & \\
\hline sheep & ulna (2) & & & & & & & & \\
\hline sheep & $\mathrm{cdv}$ & & $\mathrm{u}$ & & & & & & \\
\hline sheep & pelvis (3) & & & & & & & & \\
\hline sheep & thv & & & & & & & & \\
\hline sheep & ph1 & & & & & & & & \\
\hline sheep & humerus & $2 d$ & & & & 1 & & & \\
\hline sheep & humerus & $2 p$ & & & & & & & \\
\hline sheep & tibia & $2 d$ & & & & & & & \\
\hline sheep & tibia & $2 d$ & & & & & & & \\
\hline sheep & tibia & $2 p$ & & & & & & & \\
\hline
\end{tabular}


Table 4 (cont.) Mammal bones

\begin{tabular}{|c|c|c|c|c|c|c|c|c|c|}
\hline Species & Element & Break & Age & Butch. & Taph. & $\mathbf{R F}$ & LBF & $\mathbf{U} / \mathbf{I}$ & Comments \\
\hline sheep & tibia & $2 p$ & & & & & & & \\
\hline sheep & radius & $2 p$ & & & & 4 & 1 & 18 & \\
\hline sheep & radius & $2 p$ & & & & & & & \\
\hline sheep & radius & $2 \mathrm{~d}$ & & & & & & & \\
\hline sheep & tibia & $2 p$ & & & & & & & \\
\hline sheep & femur & $2 \mathrm{~d}$ & & & & & & & \\
\hline sheep & femur & $2 d$ & & & & & & & \\
\hline sheep & pelvis (2) & & & & & & & & \\
\hline sheep & ulna (2) & & & & & & & & \\
\hline sheep & $\mathrm{mc}$ & & & & & & & & \\
\hline sheep & scapula (3) & & & & & & & & \\
\hline sheep & $\operatorname{cev}(2)$ & & & & & & & & \\
\hline sheep & humerus & $3 d$ & & & & 22 & 1 & & \\
\hline sheep & atlas & & & & & & & & $\mathrm{r}$ \\
\hline sheep & axis & & & & & & & & $\mathrm{r}$ \\
\hline sheep & thv & & & & & & & & $\mathrm{r}$ \\
\hline sheep & scapula & & & & & & & & $r$ \\
\hline sheep & $\mathrm{mc}$ & $3 d$ & & & & 8 & & & $\mathrm{r}$ \\
\hline sheep & humerus & $8 \mathrm{~s}$ & & & & & & & $\mathrm{r}$ \\
\hline sheep & pelvis (2) & & & & & & & & \\
\hline sheep & thv & & & & & & & & $\mathrm{r}$ \\
\hline sheep & humerus & $3 d$ & & & & & & & \\
\hline sheep & vert (5) & & & & & & & & $\mathrm{r}$ \\
\hline sheep & $\operatorname{cev}(3)$ & & & & & & & & \\
\hline sheep & humerus & $3 d$ & & & & & & & \\
\hline sheep & radius & $2 p$ & up & & & & & & \\
\hline sheep & femur & $2 p$ & & & & & & & \\
\hline sheep & scapula (3) & & & & & & & & \\
\hline sheep & axis & & & & & & & & r broken \\
\hline sheep & skull (2) & & & & & & & & \\
\hline sheep & $\mathrm{mc}$ & $2 \mathrm{~d}$ & & & & & & & $\mathrm{r}$ \\
\hline sheep & femur & $2 p$ & & & & & & & \\
\hline sheep & tooth & & & & & & & & \\
\hline sheep & pelvis & & & & & & & & $\mathrm{r}$ \\
\hline sheep & mandible & & & & & & & & \\
\hline sheep & teeth (2) & & & & & & & & \\
\hline sheep & radius & $3 \mathrm{~d}$ & & & & & & & \\
\hline sheep & pelvis & & & & & & & & $\mathrm{r}$ \\
\hline sheep & $\mathrm{mc}$ & $2 p$ & & & & 2 & 1 & 16 & \\
\hline sheep & teeth (1) & & & & & & & & \\
\hline sheep & $\mathrm{mc}$ & $2 \mathrm{~d}$ & & & & & & & \\
\hline sheep & & & & & & & & & $r$ unid \\
\hline
\end{tabular}


Table 4 (cont.) Mammal bones

\begin{tabular}{|c|c|c|c|c|c|c|c|c|c|}
\hline Species & Element & Break & Age & Butch. & Taph. & $\mathbf{R F}$ & LBF & $\mathbf{U} / \mathbf{I}$ & Comments \\
\hline \multicolumn{10}{|c|}{ Period IV-V } \\
\hline cattle & & & & & & 1 & & & \\
\hline cattle & astragalus & & & & & & & & \\
\hline cattle & ph1 & & & $\operatorname{chp}$ & & & 5 & & \\
\hline cattle & radius & $8 \mathrm{~s}$ & & & & 1 & & & \\
\hline cattle & scapula & & & & & & & & \\
\hline cattle & femur & $2 d$ & & & & 39 & & & \\
\hline cattle & radius & $2 d$ & & & & & & & \\
\hline cattle & humerus & $1 p$ & & & & & & & \\
\hline cattle & $\operatorname{thv}(2)$ & & & $\operatorname{chp}$ & & & & & \\
\hline cattle & mandible & & & & & & & & \\
\hline cattle & $\operatorname{cev}(2)$ & & & & & & & & \\
\hline cattle & scapula & & & & & & & & \\
\hline cattle & pelvis & & & & & & & & \\
\hline cattle & calcaneus & & & & & & & & \\
\hline cattle & skull & & & & & 8 & & & \\
\hline cattle & & & & & & 2 & & 8 & \\
\hline sheep & & & & & & & & & $r$ unid \\
\hline sheep & scapula (2) & & $\mathrm{u}$ & & & 9 & & 6 & \\
\hline sheep & & & & & & & & & $\mathrm{r}$ unid \\
\hline sheep & mandible & & & & & & & & \\
\hline sheep & & & & & & 1 & & & \\
\hline sheep & thv & & & & & & & & \\
\hline sheep & tooth & & & & & & & & \\
\hline sheep & pelvis & & & & & & & & \\
\hline sheep & pelvis & & & & & & & & \\
\hline sheep & pelvis (2) & & & & & & & & \\
\hline sheep & tibia & $2 d$ & & & & & & & \\
\hline sheep & tibia & $2 d$ & & & & & & & \\
\hline sheep & tibia & $8 s$ & & & & & & & \\
\hline sheep & mandible & & & & & & & & $\mathrm{m} 2$ unerrupt \\
\hline sheep & thv & & & & & & & & \\
\hline sheep & scapula (6) & & & & & & & & \\
\hline sheep & femur & & & & & & & & $\mathrm{r}$ \\
\hline sheep & calcaneus & & & & & 24 & 8 & 12 & \\
\hline sheep & tibia & $3 p$ & & & & & & & $\mathrm{r}$ \\
\hline sheep & vert & & & & & & & & \\
\hline sheep & axis & & & $\operatorname{chp}$ & & & & & \\
\hline sheep & atlas & & & & & & & & \\
\hline sheep & sacrum frg & & & & & & & & \\
\hline sheep & radius & $2 p$ & & & & 12 & 3 & & \\
\hline sheep & tibia & $3 p$ & & & & & & & \\
\hline
\end{tabular}


Table 4 (cont.) Mammal bones

\begin{tabular}{|c|c|c|c|c|c|c|c|c|c|}
\hline Species & Element & Break & Age & Butch. & Taph. & $\mathbf{R F}$ & LBF & $\mathbf{U} / \mathbf{I}$ & Comments \\
\hline sheep & radius & $2 p$ & & & & & & & \\
\hline sheep & femur & $2 \mathrm{~d}$ & & & & & & & \\
\hline sheep & tibia & $8 \mathrm{~s}$ & & & & & & & \\
\hline sheep & ulna & & & & & & & & $\mathrm{r}$ \\
\hline sheep & scapula & & & & & 5 & 7 & & $\mathrm{r}$ \\
\hline sheep & astragalus & & & & & & & & $\mathrm{r}$ \\
\hline sheep & $\mathrm{mc}$ & $2 p$ & $\mathrm{u}$ & & & 22 & & 100 & $\mathrm{r}$ \\
\hline sheep & humerus & $8 s$ & & & & & & & $\mathrm{r}$ \\
\hline sheep & humerus & $2 d$ & & & & & & & \\
\hline sheep & humerus & $2 p$ & $\mathrm{u}$ & & & & & & \\
\hline sheep & radius & $2 d$ & & & & & & & \\
\hline sheep & tibia & $2 \mathrm{~d}$ & $\mathrm{u}$ & & & & & & \\
\hline sheep & horn & & & & & & & & \\
\hline sheep & mandible & & & & & & & & \\
\hline \multicolumn{10}{|l|}{ sheep } \\
\hline sheep & ulna & & & & & & & & \\
\hline sheep & scapula (6) & & & & & & & & \\
\hline sheep & $\operatorname{cev}(9)$ & & & & & & & 1 & burnt \\
\hline sheep & $\operatorname{thv}(6)$ & & & & & & & & \\
\hline sheep & calc (2) & & & & & & & & \\
\hline sheep & skull & & & & & & & & \\
\hline sheep & Ph1 & & & & & & & & \\
\hline sheep & tibia & $2 p$ & & & & & & & \\
\hline sheep & tooth & & & & & & & & \\
\hline sheep & thv & & & & & & & & \\
\hline sheep & scapula & & & & & & & & \\
\hline sheep & scapula & & & & & 5 & & & \\
\hline \multicolumn{10}{|c|}{ Period V } \\
\hline cat & femur & & $\mathrm{u}$ & & & & & & \\
\hline cat & tibia & 1 & $\mathrm{u}$ & & & & & 100 & $\mathrm{r}$ \\
\hline cattle & mc. & $2 p$ & & & & & & & \\
\hline cattle & mc. & $2 d$ & & & & & & & \\
\hline cattle & tibia & $2 p$ & & & & & & & \\
\hline cattle & tibia & $3 d$ & & & & & & & \\
\hline cattle & ph2 & 1 & & & & & & & \\
\hline cattle & ph1 & 1 & & & & & & & \\
\hline cattle & ph1 & & & & & & & & \\
\hline cattle & tibia & $2 \mathrm{~d}$ & & & & & & & \\
\hline cattle & skull & & & & & & & & \\
\hline cattle & cev & & & & & & & & \\
\hline cattle & scapula & & & & & & & & \\
\hline cattle & ulna & & & & & 1 & & & \\
\hline
\end{tabular}


Table 4 (cont.) Mammal bones

\begin{tabular}{|c|c|c|c|c|c|c|c|c|c|}
\hline Species & Element & Break & Age & Butch. & Taph. & $\mathbf{R F}$ & LBF & $\mathbf{U} / \mathbf{I}$ & Comments \\
\hline cattle & femur & $8 \mathrm{~s}$ & & & & & & & \\
\hline cattle & femur & $2 p$ & & & & 3 & & & \\
\hline cattle & thv & & & & & & & 2 & \\
\hline cattle & radius & & & & & & & & \\
\hline cattle & radius & & $\mathrm{u}$ & & & 1 & & & \\
\hline cattle & humerus & $2 p$ & & & & 2 & & 15 & \\
\hline cattle & mc. & $2 p$ & & & & & & & \\
\hline cattle & mc. & $2 \mathrm{~d}$ & & & & 1 & & & \\
\hline cattle & skull & & & & & & & & \\
\hline cattle & mandible & & & & & & & & m2 half erupt. \\
\hline cattle & radius & $2 p$ & & & & & & & \\
\hline cattle & tibia & $3 p$ & & & & 6 & & 24 & \\
\hline cattle & ulna & & & & & & & & \\
\hline cattle & ph1 & & & & & & & & \\
\hline cattle & scapula & & & & & & & & \\
\hline cattle & lbv & & & & & & & & \\
\hline cattle & thv & & $\mathrm{u}$ & & & & & & \\
\hline cattle & ph3 & & & & & & & & \\
\hline cattle & pelvis (2) & & & & & & & & \\
\hline cattle & & & & & & & & 3 & \\
\hline cattle & humerus & $2 p$ & & & & & & 2 & \\
\hline cattle & tibia & $8 \mathrm{~s}$ & & & & & & & \\
\hline cattle & humerus & $2 \mathrm{~d}$ & & & & & & & \\
\hline cattle & carpal & & & & & & & & \\
\hline cattle & & & & & & 1 & & & $\mathrm{r}$ all unid \\
\hline cattle & astragalus & & & $\operatorname{chp}$ & & 1 & & & \\
\hline cattle & radius & $3 p$ & & & & & & & \\
\hline cattle & tibia & $2 \mathrm{~d}$ & & & & 4 & & 11 & \\
\hline cattle & calcaneus & & & & & & & & 7 frgs burnt bn \\
\hline cattle & & & & & & 1 & & & \\
\hline cattle & pelvis & & & & & & & & \\
\hline cattle & femur & $3 p$ & & & & & & & \\
\hline cattle & $\operatorname{cdv}(2)$ & & & & & & & & \\
\hline cattle & cad & & & & & & & & \\
\hline cattle & ph2 & & & & & 2 & 13 & 8 & \\
\hline cattle & carpal frag. & & & & & & & & \\
\hline cattle & atlas frag. & & & & & & & & \\
\hline cattle & femur & $3 p$ & up & & & & & & \\
\hline cattle & pelvis (3) & & & $\operatorname{chp}$ & & & & & \\
\hline cattle & femur & $3 d$ & & $\operatorname{chp}$ & & & & & \\
\hline cattle & $\mathrm{mt}$ & $3 \mathrm{~d}$ & & & & & & & \\
\hline cattle & ph3 & 1 & & & & & & & \\
\hline
\end{tabular}


Table 4 (cont.) Mammal bones

\begin{tabular}{|c|c|c|c|c|c|c|c|c|c|}
\hline Species & Element & Break & Age & Butch. & Taph. & RF & LBF & $\mathbf{U} / \mathbf{I}$ & Comments \\
\hline cattle & $c d v$ & 1 & & & & & & & \\
\hline cattle & scapula (3) & & & & & & & & \\
\hline cattle & $\operatorname{cev}(2)$ & & & & & & & & \\
\hline cattle & teeth $(4)$ & & & & & & & & \\
\hline cattle & radius & $3 p$ & & & & & & & \\
\hline cattle & ulna & & & & & & & & \\
\hline cattle & $\mathrm{mc}$ & $2 d$ & & & & & & & \\
\hline cattle & thv & & & & & & & & \\
\hline cattle & $\mathrm{mc}$ & $2 p$ & $\mathrm{u}$ & & & & & & \\
\hline cattle & femur & $2 p$ & $\mathrm{u}$ & & & 13 & 4 & 68 & \\
\hline cattle & tibia & $3 d$ & & & & & & & \\
\hline cattle & astragalus & 1 & & & & & & & \\
\hline cattle & humerus & $3 \mathrm{~d}$ & & & & 2 & & & \\
\hline cattle & ph2 & & & & & & & & \\
\hline cattle & tibia & & & & & & & & \\
\hline cattle & radius & $2 p$ & & & & 3 & & 6 & \\
\hline cattle & $\mathrm{mp}$ & 1 & & & & & & & \\
\hline cattle & cev & & & & & & & 4 & \\
\hline cattle & tibia & $2 p$ & & & & & & & \\
\hline cattle & tibia & $2 p$ & & & & & & & \\
\hline cattle & skull (11) & & & & & & & & \\
\hline cattle & hyoid & & & & & & & & \\
\hline cattle & scapula & & & & & & & & \\
\hline cattle & cev & & & & & & & & \\
\hline cattle & radius & $3 p$ & & & & & & & \\
\hline cattle & humerus & $2 p$ & & & & & & & \\
\hline cattle & ph2 & & & & & & & & \\
\hline cattle & tibia & $3 d$ & & & & & & & \\
\hline cattle & cev & & $\mathrm{u}$ & & & & & & \\
\hline cattle & tibia & $3 p$ & & & & 10 & 4 & & \\
\hline cattle & tibia & $3 \mathrm{~d}$ & & & & & & & \\
\hline cattle & phal. & & & & & & & & \\
\hline cattle & scapula (2) & & & & & & & & \\
\hline cattle & ulna & & & $\operatorname{chp}$ & & & & & \\
\hline cattle & femur & $2 p$ & & & & & & & \\
\hline cattle & femur & $2 p$ & & & & & & & \\
\hline cattle & radius & $2 p$ & & $\operatorname{chp}$ & & & & & \\
\hline cattle & humerus & $2 d$ & & & & & & & \\
\hline cattle & humerus & $2 p$ & & & 4 & 13 & & & \\
\hline cattle & skull & & & & & & & & \\
\hline pig & tooth & & & & & & & & \\
\hline sheep & tooth & & & & & 1 & & & \\
\hline
\end{tabular}


Table 4 (cont.) Mammal bones

\begin{tabular}{|c|c|c|c|c|c|c|c|c|c|}
\hline Species & Element & Break & Age & Butch. & Taph. & $\mathbf{R F}$ & LBF & $\mathbf{U} / \mathbf{I}$ & Comments \\
\hline sheep & $\mathrm{mt}$ & $2 p$ & & & & & & & \\
\hline sheep & calcaneus & 1 & & & & & & & \\
\hline sheep & thv & & & & & & & & \\
\hline sheep & pelvis & & & & & & & & \\
\hline sheep & tibia & $2 \mathrm{~d}$ & & & & 3 & & 6 & \\
\hline sheep & femur & $2 p$ & & & & & & & \\
\hline sheep & femur & $8 \mathrm{~s}$ & & & & & & & \\
\hline sheep & ulna & & $\mathrm{u}$ & & & 5 & & 4 & \\
\hline sheep & tibia & & & & & & & & \\
\hline sheep & $\mathrm{mt}$ & & & & & & & & \\
\hline sheep & mandible & & & & & & & & \\
\hline sheep & cev & & & & & & & & \\
\hline sheep & thv & & & & & & & & \\
\hline sheep & & & & & & & & & \\
\hline sheep & tooth & & & & & & & & \\
\hline sheep & $\mathrm{mt}$ & $2 p$ & & & & & & & \\
\hline sheep & & & & & & & & 3 & \\
\hline sheep & tibia & $2 \mathrm{~d}$ & & & & & & 4 & \\
\hline sheep & & & & & & 8 & & 40 & \\
\hline sheep & tibia & $2 p$ & & & & & & & \\
\hline sheep & pelvis & & & & & & & 8 & \\
\hline sheep & ulna & & & & & 3 & & & \\
\hline sheep & $\mathrm{mt}$. & $2 \mathrm{~d}$ & & & & & & & \\
\hline sheep & $\mathrm{mt}$. & $2 p$ & & & & 1 & & & \\
\hline sheep & calcaneus & & & & & & & & $\mathrm{r}$ all unid \\
\hline sheep & & & & & & & & 2 & 2 frgs burnt \\
\hline sheep & scapula & & & & & 2 & & 4 & \\
\hline sheep & tibia & $8 \mathrm{~s}$ & & & & & & & \\
\hline sheep & & & & & & & 4 & & \\
\hline sheep & ph1 & & & & & & & & \\
\hline sheep & scapula & & & & & & & & \\
\hline sheep & teeth (2) & & & & & & & & \\
\hline sheep & skull & & & & & & & & \\
\hline sheep & pelvis (2) & & & & & & & & \\
\hline sheep & femur & $3 p$ & up & & & & & & \\
\hline sheep & & & & & & & & & $r$ all unid \\
\hline sheep & tibia & $3 \mathrm{~d}$ & & & & & & & \\
\hline sheep & thv & & & & & & & & \\
\hline sheep & $\mathrm{mt}$ & $2 \mathrm{~d}$ & & & & & & & \\
\hline sheep & teeth (3) & & & & & 17 & 7 & 21 & \\
\hline sheep & pelvis (3) & & & & $\mathrm{g}$ & & & & \\
\hline sheep & mandible & & & & & & & & \\
\hline
\end{tabular}


Table 4 (cont.) Mammal bones

\begin{tabular}{|c|c|c|c|c|c|c|c|c|c|}
\hline Species & Element & Break & Age & Butch. & Taph. & $\mathbf{R F}$ & LBF & $\mathbf{U} / \mathbf{I}$ & Comments \\
\hline sheep & scapula (2) & & & & $\mathrm{g}$ & & & & \\
\hline sheep & & & & & & & & & \\
\hline sheep & tooth (1) & & & & & & & & \\
\hline phasheep & mandible & & & & & & & & \\
\hline sheep & $\mathrm{mc}$ & 1 & $\mathrm{u}$ & & & & & & \\
\hline sheep & humerus & $3 d$ & & & & & & & \\
\hline sheep & humerus & $3 d$ & & & $\mathrm{~g}$ & 1 & & 3 & \\
\hline sheep & & & & & & & 2 & & \\
\hline sheep & pelvis & & & & & 1 & & 3 & \\
\hline sheep & & & & & & 2 & & 1 & \\
\hline sheep & pelvis & & & & & & & & \\
\hline sheep & atlas & & & $\operatorname{chp}$ & & & & & \\
\hline sheep & humerus & $3 d$ & & & & & & 6 & \\
\hline sheep & humerus & & & & & & & & \\
\hline sheep & humerus & & & & & 1 & & & \\
\hline sheep & radius & $2 d$ & $\mathrm{u}$ & & & & & & \\
\hline sheep & radius & $2 p$ & & & & & & & \\
\hline sheep & ulna & & & & & & & & \\
\hline sheep & atlas & & & & & & & & \\
\hline sheep & femur & head & & & & & & & \\
\hline
\end{tabular}

Key

Element calc: calcaneus; cdv: caudal vertebra; cev: cervical vertebra; lbv: lumbar vertebra; mc: metacarpal; mt: metatarsal; ph1: phalanx 1; phal: phalanx; thv: thoracic vertebra

Break (breakage) 2p: $20 \%$ of shaft present plus proximal epiphysis; $2 \mathrm{~d}: 20 \%$ of shaft present plus distal epiphysis; $8 \mathrm{~s}$ : $80 \%$ of shaft (only) present; 1: complete bone

Age u: unfused; f: fused; up: unfused proximal

Butch. (butchery) chp: chop mark present

Taph (taphonomy) g: evidence of gnawing

$R F$ number of rib fragments

$L B F$ number of broken long bone fragments

$U / I$ number of unidentified fragments.

Comments r: material from sieved samples; unid: unidentified; bn: bone; unerrup: unerrupted.

important source of food and it has been noted (Smith 1877, 112) that bones of slaughtered animals were stored after the meat was removed and kept for periods of food shortage. Evidence of excessive chopping of the bone occurs in Periods IV and V also, indicating that this was not just a phenomenon associated with the early years.

A large number of sheep long bones displayed evidence of gnawing, suggesting that they were finally used to feed cats or dogs.

\subsection{Small mammals}

Cat (Felis catus) was represented by an unfused femur and tibia respectively. Mature hare (Lepus timidus), common house mouse (Mus domesticus), common shrew (Sorex araneus) and field vole (Microtus agrestis) were also present. As most of these contexts show signs of disturbance it can be said that the majority of the mouse bones are likely to be intrusive.

The cat bones, unlike those found at Pluscarden Priory or Rattray Castle (McCormick 1994, 412; McCormick forthcoming) did not display any cut marks so it cannot be said if skinning took place or if the Dundrennan cat was eaten (as may have been the case at Pluscarden). The hare bone did not display any visible signs of butchery either but this species is known to have been hunted widely as game.

\subsection{Birds}

A large quantity of bird bones was recovered from Period IV and V contexts. The majority of the bones were of domestic fowl (Gallus gallus, 72\%), followed by domestic goose (Anser anser, 13.8\%). Other 
Table 5 Fusion of cattle and sheep bones

\begin{tabular}{|c|c|c|c|c|}
\hline Cattle & months & element & fused & unfused \\
\hline \multicolumn{5}{|c|}{ Period 1} \\
\hline & \multirow[t]{2}{*}{$7-10$} & scapula & & 1 \\
\hline & & pelvis & & 2 \\
\hline & \multirow[t]{2}{*}{$12-18$} & humerus d & & 1 \\
\hline & & radius $\mathrm{p}$ & & 2 \\
\hline & $24-30$ & metac d & & \\
\hline & \multirow[t]{2}{*}{$27-36$} & metat d & & 1 \\
\hline & & tibia d & & \\
\hline & $36-42$ & calc & & 1 \\
\hline & 42 & femur & & 2 \\
\hline & \multirow[t]{4}{*}{$42-48$} & humerus $\mathrm{p}$ & & 1 \\
\hline & & radius $\mathrm{d}$ & & 1 \\
\hline & & femur d & & 2 \\
\hline & & ulna $\mathrm{p}$ & & \\
\hline \multicolumn{5}{|c|}{ Period 2} \\
\hline & \multirow[t]{2}{*}{$7-10$} & scapula & 1 & 1 \\
\hline & & pelvis & 3 & 1 \\
\hline & \multirow[t]{2}{*}{$12-18$} & humerus d & 2 & \\
\hline & & radius $\mathrm{p}$ & 1 & \\
\hline & \multirow[t]{2}{*}{$24-30$} & metac d & 2 & \\
\hline & & tibia d & 2 & \\
\hline & $27-36$ & metat d & 1 & \\
\hline & $36-42$ & calcaneus & 1 & 1 \\
\hline & 42 & femur $p$ & 1 & \\
\hline & $42-48$ & humerus $p$ & 1 & \\
\hline & & radius d & & \\
\hline & & femur d & 1 & \\
\hline & & ulna $\mathrm{p}$ & 1 & \\
\hline \multicolumn{5}{|c|}{ Period V } \\
\hline & \multirow[t]{2}{*}{$7-10$} & scapula & & \\
\hline & & pelvis & & \\
\hline & \multirow[t]{2}{*}{$12-18$} & humerus d & 2 & \\
\hline & & radius $\mathrm{p}$ & 3 & \\
\hline & \multirow[t]{2}{*}{$24-30$} & metac d & 2 & \\
\hline & & tibia d & 6 & 1 \\
\hline & $27-36$ & metat d & 1 & \\
\hline & $36-42$ & calcaneus & 1 & \\
\hline & 42 & femur $p$ & 1 & 1 \\
\hline & \multirow[t]{4}{*}{$42-48$} & humerus $\mathrm{p}$ & 3 & \\
\hline & & radius $\mathrm{d}$ & 4 & \\
\hline & & femur d & 1 & \\
\hline & & ulna $\mathrm{p}$ & 1 & \\
\hline
\end{tabular}

\begin{tabular}{|c|c|c|c|c|}
\hline Sheep & months & element & fused & unfused \\
\hline \multicolumn{5}{|c|}{ Period II } \\
\hline & \multirow[t]{4}{*}{$6-10$} & scapula & 1 & \\
\hline & & radius $\mathrm{p}$ & & \\
\hline & & pelvis & & \\
\hline & & humerus $\mathrm{d}$ & 3 & \\
\hline & \multirow[t]{3}{*}{$18-28$} & metac & & \\
\hline & & tibia d & 1 & \\
\hline & & metat & 1 & \\
\hline & \multirow[t]{7}{*}{$30-42$} & radius $d$ & & \\
\hline & & femur d & & \\
\hline & & humerus $\mathrm{p}$ & 1 & \\
\hline & & femur $p$ & & \\
\hline & & tibia $\mathrm{p}$ & 1 & \\
\hline & & ulna & 1 & \\
\hline & & calcaneus & 1 & \\
\hline \multicolumn{5}{|c|}{ Period IV } \\
\hline & \multirow[t]{4}{*}{$6-10$} & scapula & 3 & \\
\hline & & radius $p$ & 3 & 1 \\
\hline & & pelvis & 6 & \\
\hline & & humerus d & 5 & \\
\hline & \multirow[t]{3}{*}{$18-28$} & metac & 7 & \\
\hline & & tibia d & 8 & 1 \\
\hline & & metat & 1 & \\
\hline & \multirow[t]{6}{*}{$30-42$} & radius $\mathrm{d}$ & 4 & \\
\hline & & femur d & 2 & \\
\hline & & humerus $\mathrm{p}$ & & 1 \\
\hline & & femur $p$ & 2 & 1 \\
\hline & & tibia $\mathrm{p}$ & 7 & 1 \\
\hline & & ulna & 0 & \\
\hline \multicolumn{5}{|c|}{ Period V } \\
\hline & \multirow[t]{4}{*}{$6-10$} & scapula & 2 & \\
\hline & & radius $\mathrm{p}$ & 4 & 1 \\
\hline & & pelvis & 8 & \\
\hline & & humerus d & 6 & \\
\hline & \multirow[t]{3}{*}{$18-28$} & metac & & 1 \\
\hline & & tibia $d$ & 7 & \\
\hline & & metat & 3 & \\
\hline & \multirow[t]{7}{*}{$30-42$} & radius d & 3 & 3 \\
\hline & & femur d & & \\
\hline & & humerus $\mathrm{p}$ & 1 & 3 \\
\hline & & femur $p$ & 2 & 1 \\
\hline & & tibia $p$ & 5 & 1 \\
\hline & & ulna & 1 & 3 \\
\hline & & calcaneus & 1 & \\
\hline
\end{tabular}

Key

d: distal; metac: metacarpal; metat: metatarsal; p: proximal 
species included teal (Anas crecca, 2\%), mallard (Anas platyrhynchos 1.3\%), whimbrel (Numenius phaeopus, $1.3 \%$ ), jackdaw (Corvus monedula, 1.8\%) and snipe (Gallinago gallinago, 1.3\%). A single humerus morphologically similar and matching in size to merlin (Falco columbarius) was present (representing $1.3 \%$ of the assemblage). A list of all species and parts present is given by Table 6 .

Poultry was eaten extensively by the monks who were officially allowed to eat the meat of two- but not four-legged creatures. Domestic fowl and goose appeared also as the primary bird remains in excavated assemblages from the Observantine friary at Jedburgh and a Valliscaulian house at Pluscarden (Groves forthcoming; Hamilton-Dyer 1994, 414). Some jackdaw bones were also noted at Pluscarden. None of the Dundrennan fowl tarsometatarsii remained intact, but where it could be ascertained from the lower distal shaft area, it was noted that no spurs or spur scars were present, indicating the presence of female birds only in these instances. Records from the rental of Braemar dating from 1557 , mention ' 176 reik hens at 4 $\mathrm{d}$ each'. Reik hens are farmyard hens and formed part of the rent paid in kind by tenants (Shirley 1926, 25). The majority of the Dundrennan bones were mature, indicating that the birds were likely to have been kept until later in life as suppliers of eggs.

A number of the fowl humeri displayed cut marks on the proximal bicippital surface, and a further few displayed cuts on the distal condyles of the tibiotarsii. Cut marks in these areas are consistent with the removal of the wing bones and leg bones, probably after cooking. All skeletal elements were present indicating the chickens were likely to have been cooked whole in the pot. A number of the fowl bones display tooth marks in the area of the distal condyles, indicating that the bones were finally chewed by cats or dogs.

The presence of teal and mallard imply that the monks enjoyed wild game on occasion. Wild birds recorded as having been eaten in religious houses are quite varied and included curlew and snipe (Black 1993). This may account for the presence of snipe and whimbrel (small curlew) in the sample.

The merlin (the smallest of the falcons) may have been used for hunting. That monks and neighbouring landowners sometimes came into dispute over hunting rights is illustrated by an agreement in 1235, between the monks of Melrose and Roger Avenel, regarding rights to the eyries of goshawks and sparrow hawks (Shirley 1926, 15). The records attest also to the widespread protection of hawks. Hawking may have been an important occupation of the monks, not only for sport, but to provide small birds for the table on those days when other meat was forbidden.
Table 6 Bird bone

\begin{tabular}{|c|c|c|c|c|}
\hline Species & Element & Break & Age & Butchery Taphonomy \\
\hline \multicolumn{5}{|c|}{ Period II } \\
\hline & $\mathrm{cmc}$ & & & \\
\hline \multicolumn{5}{|c|}{ Period IV } \\
\hline & tibio-t & & & \\
\hline & $\mathrm{cmc}$ & & & \\
\hline & sternum & & & \\
\hline & tooth & & & \\
\hline & femur & $2 \mathrm{p}$ & & \\
\hline & pelvis & & & \\
\hline & skull & & & \\
\hline & radius & $9 p$ & & \\
\hline & scapula & & & \\
\hline & pelvis & & & \\
\hline & pubis & & & \\
\hline & sternum & & & \\
\hline $\mathrm{df}$ & sternum frg & & & \\
\hline $\mathrm{df}$ & tibia & & & \\
\hline $\mathrm{df}$ & femur & $3 p$ & & \\
\hline $\mathrm{df}$ & humerus & & & $\operatorname{chp}$ \\
\hline $\mathrm{df}$ & scapula frg & & & \\
\hline $\mathrm{df}$ & ulna & & & \\
\hline $\mathrm{df}$ & coracoid & & & \\
\hline $\mathrm{df}$ & tibio-t & $9 \mathrm{~d}$ & & \\
\hline $\mathrm{df}$ & pelvis frg & & & \\
\hline $\mathrm{df}$ & tibio-t & 1 & & \\
\hline $\mathrm{df}$ & tibio-t & 1 & & \\
\hline $\mathrm{df}$ & humerus & $8 \mathrm{~s}$ & $\mathrm{u}$ & \\
\hline $\mathrm{df}$ & $\operatorname{tmt}$ & 1 & & \\
\hline df & humerus & $3 p$ & & \\
\hline $\mathrm{df}$ & & $9 \mathrm{~d}$ & & $\mathrm{~g}$ \\
\hline $\mathrm{df}$ & sternum & & & \\
\hline $\mathrm{df}$ & & & & \\
\hline $\mathrm{df}$ & tmt & $9 \mathrm{~d}$ & & \\
\hline $\mathrm{df}$ & humerus & $2 \mathrm{p}$ & $\mathrm{u}$ & \\
\hline df & $\mathrm{cmc}$ & & & \\
\hline $\mathrm{df}$ & ulna & 1 & & \\
\hline $\mathrm{df}$ & ulna & $2 \mathrm{~d}$ & & \\
\hline $\mathrm{df}$ & femur & $2 \mathrm{~d}$ & & \\
\hline $\mathrm{df}$ & femur & 1 & & \\
\hline $\mathrm{df}$ & coracoid & 1 & & \\
\hline $\mathrm{df}$ & ulna & & & \\
\hline $\mathrm{df}$ & radius & & & \\
\hline $\mathrm{df}$ & humerus & $9 \mathrm{~d}$ & $\mathrm{u}$ & \\
\hline $\mathrm{df}$ & ulna & $9 \mathrm{~d}$ & & \\
\hline $\mathrm{df}$ & sternum & & & \\
\hline $\mathrm{df}$ & furcula frgs & & & \\
\hline $\mathrm{df}$ & pelvis & & & \\
\hline $\mathrm{df}$ & tibia & $9 p$ & & \\
\hline
\end{tabular}




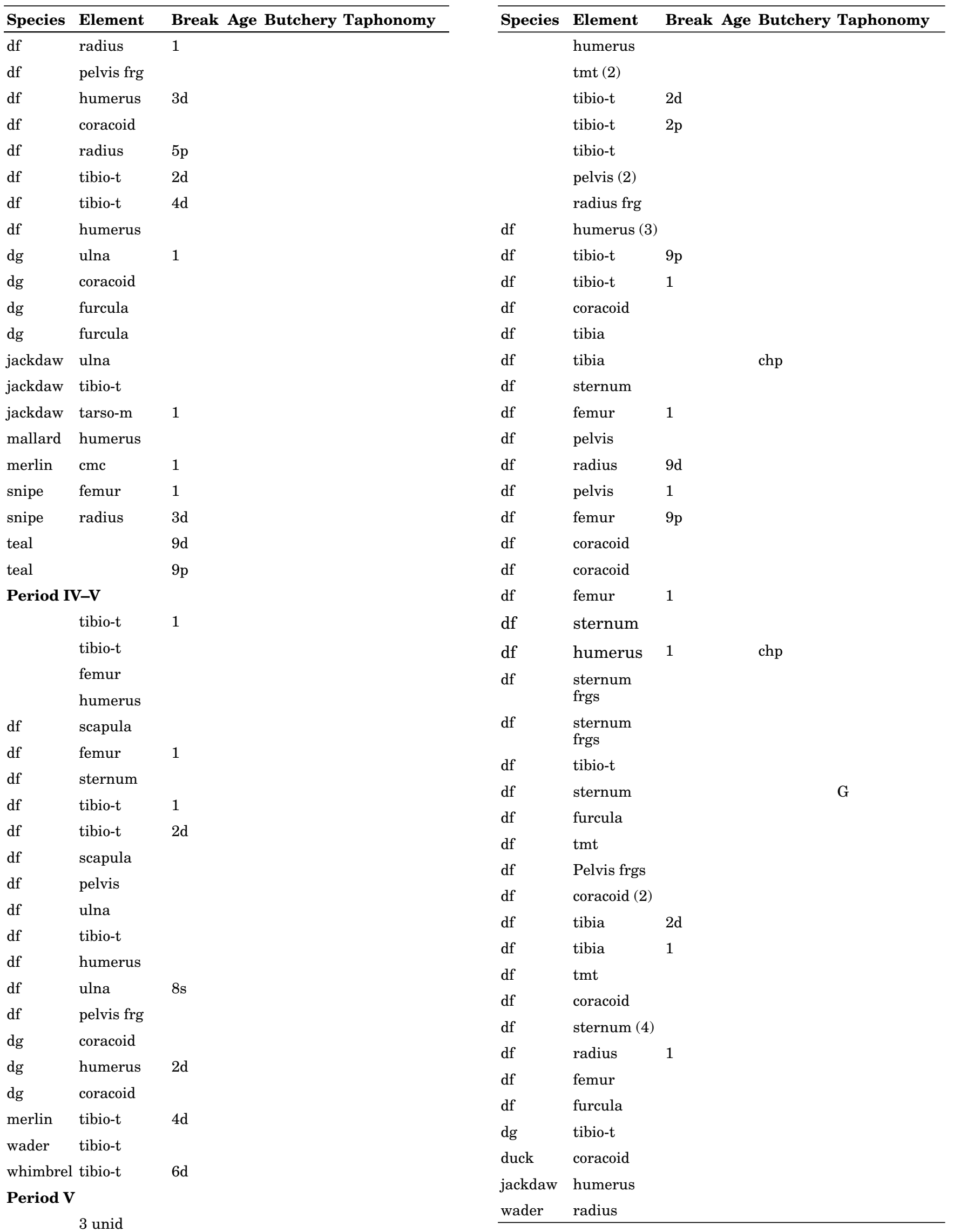

3 unid

femur

shaft

cmc (2) 1

humerus

Species: dg: domestic goose; df: domestic fowl

Break (breakage) 2p: $20 \%$ of shaft present plus proximal epiphysis; $2 \mathrm{~d}$ : $20 \%$ of shaft present plus distal epiphysis; $8 \mathrm{~s}: 80 \%$ of shaft (only) present; 1: complete bone

Age u: unfused Butch. (butchery) chp: chop mark present

Taph (taphonomy) g: evidence of gnawing 


\section{Fish and crustaceans by Ruby Céron Carrasco}

Sieved samples from 36 contexts produced fish remains. The samples were sieved through a $1 \mathrm{~mm}$ mesh for retents and $300 \mu \mathrm{m}$ for flots. Twelve samples were hand-collected on site. All the fish bone recovered was examined and identified to species where possible or to family level. Identification was done by comparison with a modern fish bone collection and by reference to relevant guides (Boyle et al in press; Rosello-Izquierdo 1988). The incidence of species in each period is given in Table 7.

The size of identified non-Gadoid species was calculated by comparison to modern specimens of known size. The size of Gadoid species has been calculated by giving an approximate size range. This was done by matching the archaeological material to modern fish skeletons of known size based on 'total body length'. Therefore, the elements were categorised as 'very small' ( $<15 \mathrm{~cm})$, 'small' (15-30 $\mathrm{cm})$, 'medium' (30-60 cm), 'large' $(60-120 \mathrm{~cm})$ and 'very large' ( $>120 \mathrm{~cm}$ ).

Where appropriate, the major paired elements were assigned to the left or right side of the skeleton. All elements were examined for signs of butchery, and burning was also noted. The condition of the bone was recorded in all cases. The recording of condition was based on two characteristics: texture on a scale of 1 to 5 (fresh to extremely friable), and erosion on a scale of 1 to 5 (none to extreme). The sum of both was used as an indication of bone condition; fresh to extremely poorly preserved on a scale of 1 to 10 (after Jones 1991). The details of these analyses are tabulated in the archive of the project records at the National Monuments Record of Scotland and only a few of the main points are summarised here.

Table 7 Fish bones

\begin{tabular}{lccc}
\hline Species & Period I & Period IV & Period V \\
\hline Gadidae (cod family) & 49 & 861 & 143 \\
cf Gadidae & 0 & 22 & 0 \\
Gadus morhua (cod) & 0 & 50 & 3 \\
cf Gadus morhua & 1 & 20 & 0 \\
Melanogrammus aeglefinus (haddock) & 0 & 8 & 5 \\
cf Melanogrammus aeglefinus & 0 & 2 & 0 \\
Pollachius virens (saithe/coal fish) & 11 & 21 & 4 \\
Pollachius Pollachius (pollack) & 116 & 142 & 0 \\
cf Pollachius Pollachius & 0 & 0 & 23 \\
Clupea heringus (herring) & 141 & 478 & 82 \\
Limanda limanda (dab) & 5 & 180 & 158 \\
cf. Limanda limanda & 0 & 197 & 319 \\
Pleuronectidae (right-eyed flatfishes) & 0 & 150 & 16 \\
Raja clavata (rocker) & 14 & 26 & 6 \\
Gurnardus gurnardus (gurnard) & 20 & 24 & 3 \\
Zeus faber (john dory) & 0 & 0 & 5 \\
Salmonidae & 59 & 9 & 10 \\
Perca fluviatilis (perch) & 37 & 42 & 114 \\
Rutilus rutilus (roach) & 0 & 6 & 0 \\
Anguilla anguilla (eel) & 0 & 15 & 10 \\
Petromyzonidae (lamprey) & 0 & 2254 & 901 \\
Total & 453 & &
\end{tabular}


Period I Although only three contexts from Period I contained fish remains, ten different species were identified, of which the most abundant were herring (Clupea harengus) and 'small' size pollack (Pollachius pollachius).

Period IV Thirty contexts from this period contained fish remains, with fifteen different species identified. Gadidae were the most abundant, with pollack (Pollachius pollachius) being one of the dominant species identified. Other important species were the flatfishes of the Pleuronectidae family including dab (Limanda limanda). Herring (Clupea harengus) was also important.

Period V Five contexts from this period contained fish remains. Fourteen different species were identified, of which the dominant species present was the flatfish dab (Limanda limanda). The other important taxa were the Gadidae and herring (Clupea harengus).

\subsection{Freshwater fish}

The freshwater fishes present at Dundrennan were Salmonidae (salmon or trout), perch (Perca fluviatilis), eel (Anguilla anguilla) and roach (Rutilus rutilus). While salmon, trout and eel are flowing-river fish and may have been caught at burn entrances, perch and roach are lake and slow-moving river inhabitants and easily adapt to living in canals and ponds (Wheeler 1978). The use of fish ponds by medieval monasteries in Scotland has not been widely studied. The possible presence of fish ponds at Dundrennan and the recovery of fish elements from species such as perch and roach open interesting perspectives in the study and understanding of the economy and dietary rules of the monastic houses throughout Scotland.

Perch and roach were mainly represented by scale remains. Very few vertebrae were recovered from these species, which may indicate that the fish were scaled before preparation for food.

Period IV deposits contained the remains of the keratinized teeth of lamprey. This is the only hard part of lampreys and may survive in some archaeological deposits (Wheeler \& Jones 1989). Although this species of the superclass Agnatha $(A=$ without, gnathos = jaws), has quite an unprepossessing appearance, it has been commonly eaten in Europe. Scotland is no exception; in 1304 lampreys were imported from France to supply the king while staying at St. Andrews (Anson 1950).

\subsection{Marine fish}

Herring is particularly numerous in Period IV, and was represented almost entirely by vertebrae. Vertebrae are the most robust elements and so may have survived preferentially. Dundrennan may have been supplied with herring from a variety of sources. One of these could have been Loch Ryan, some $70 \mathrm{~km}$ to the west, where a prolific herring industry formerly flourished.
Gadidae were generally represented by 'small' specimens - mainly haddock, pollack and saithe. Some elements from 'large' cod were also recovered; some of these were large enough to be handretrieved on site. Period IV contained most of the Gadidae and included elements identified to pollack, saithe, cod and haddock. These have a long history as important sources of food and may either have been consumed fresh or as salted or dried products This industry had been in practice from at least Norse times and expanded during postmedieval times to cater for Christian dietary norms, especially for Lent and other religious events, in which eating of meat was forbidden.

Flatfish from the Pleuronectidae family (righteyed flatfishes), in particular dab (Limanda limanda), were especially abundant in Periods IV and V. Dab live over sandy ground and are found inshore all the year round. It is not surprising therefore that so much dab was recovered at Dundrennan, with the proximity of sandy coast around the Solway Firth.

\subsection{Fish in economy and diet}

Fish resources have played an important part in the religious and social history of Scotland. Many abbeys and other religious houses were granted fishing rights by the kings of Scotland, for example the Valliscaulian houses of Pluscarden, Beauly and Ardchattan derived a large part of their incomes from salmon fisheries from their foundation early in the 13th century (Anson 1950, 37).

In addition it is well-known that the Cistercians were experts in fish-farming. Many abbeys appointed a frater piscatorius for managing their fishponds and the sale of their products (Tobin 1995, 128). The presence of possible fishpond species at Dundrennan is therefore compatible with the historical evidence, although the evidence from Dundrennan is for consumption on site. It is not known whether the products of the fish-ponds were also traded.

The products of sea fishing were consumed at the abbey and could have derived from local areas, for example around the Solway Firth and the wellknown herring fishery at Loch Ryan. The presence and abundance of flatfish in Periods IV and V may be indicative of a change in dietary rules or preferences at the abbey.

\subsection{Crustaceans}

Three fragments of crustacean remains were recovered from Period IV deposits. These fragments may have belonged to the edible crab (Cancer pagurus) but were too small for size determination or accurate identification. The species can be found among rocks and would have been readily available nearby. 


\section{Molluses by Stephen Carter}

\subsection{Marine molluscs}

\subsubsection{Methods}

Marine shells were recovered by hand-retrieval and from sieved samples. The bulk samples were sieved through a $1 \mathrm{~mm}$ mesh and all apical and non-apical fragments were recovered. The apical fragments were identified to species using a reference collection and standard guides; and frequency was estimated by counting shell apices for gastropods and valve umbos for bivalve species (Campbell 1989; Carter 1992; Moreno-Nuno 1994a; Moreno-Nuno 1994b)

\subsubsection{Results}

In the hand-collected material only whole specimens were recovered, which indicates that they were refuse from foodstuff. The sieved materials contained remains of food debris and mortar-related shell fragments. The mortar-related shells were very fragmented, preventing precise quantification: instead a relative scale of abundance was adopted. Mortar-related shell fragments were also recognisable because they are usually burnt, thus acquiring a distinctive grey colour, and often have mortar lumps attached to them. The incidence of species in each period is given by Table 8 .

\subsubsection{Discussion}

The material derives from domestic refuse and from mortar components. In the domestic material, the most common species are the common cockle (Cerastoderma edule) and the common mussel (Mytilus edulis). Most of the species present are sand burrowing species and would have been easily collected from the sandy beaches of the Solway Firth.

Table 8 Marine molluscs

\begin{tabular}{|c|c|c|c|c|c|c|}
\hline Species & Retrieval & Period I & Period II & Period IV & Per. IV-V & Period V \\
\hline \multirow[t]{2}{*}{ Ostrea edulis (oyster) } & by hand & 1 & 2 & 38 & 5 & 15 \\
\hline & sieved & 1 & & 14 & 9 & 1 \\
\hline \multirow{2}{*}{$\begin{array}{l}\text { Littorina littorea (edible } \\
\text { periwinkle) }\end{array}$} & by hand & & & 17 & 6 & 139 \\
\hline & sieved & $* * *$ & & $* * * * 24$ & 4 & 1 \\
\hline \multirow{2}{*}{$\begin{array}{l}\text { Littorina littorinas (flat } \\
\text { periwinkle) }\end{array}$} & by hand & & & & & \\
\hline & sieved & & & $* * * * *$ & & \\
\hline \multirow{2}{*}{$\begin{array}{l}\text { Cerasto-derma edule } \\
\text { (common cockle) }\end{array}$} & by hand & & 5 & 53 & 16 & \\
\hline & sieved & $* * * 2$ & & $* * * * 109$ & $* * * 11$ & $* * 5$ \\
\hline \multirow{2}{*}{$\begin{array}{l}\text { Buccinum undatum (common } \\
\text { whelk) }\end{array}$} & by hand & 1 & & 7 & 2 & 2 \\
\hline & sieved & & & 6 & 2 & \\
\hline \multirow{2}{*}{$\begin{array}{l}\text { Mytilus edulis (common } \\
\text { mussel) }\end{array}$} & by hand & & & 8 & 18 & 24 \\
\hline & sieved & $* * *$ & & $* * * * 13$ & 31 & 2 \\
\hline \multirow[t]{2}{*}{ Patella sp. (limpet) } & by hand & & & 1 & 1 & 2 \\
\hline & sieved & & & & 1 & 9 \\
\hline \multirow{2}{*}{$\begin{array}{l}\text { Turritella communis (tower } \\
\text { shell) }\end{array}$} & by hand & & & 1 & & 1 \\
\hline & sieved & $* * 1$ & & $* * * * 7$ & & \\
\hline \multirow[t]{2}{*}{ Spisula solida (trough shell) } & by hand & & & 1 & & 1 \\
\hline & sieved & & & $* * * 1$ & & \\
\hline \multirow{2}{*}{$\begin{array}{l}\text { Eliminus modestus } \\
\text { (barnacles) }\end{array}$} & by hand & & & & & 1 \\
\hline & sieved & & & & & \\
\hline \multirow[t]{2}{*}{ Gari depressa (sunset shell) } & by hand & & & & & \\
\hline & sieved & & & 2 & & \\
\hline
\end{tabular}

Key: * indicates relative abundance of fragments in one or more contexts per period 
Table 9 Non-marine molluses

\begin{tabular}{|c|c|c|c|c|c|c|c|c|}
\hline \multirow{2}{*}{$\begin{array}{l}\text { Period (various contexts) } \\
\text { Taxa }\end{array}$} & \multirow{2}{*}{$\begin{array}{c}I \\
\text { floors }\end{array}$} & \multicolumn{5}{|c|}{ IV } & \multirow{2}{*}{$\begin{array}{l}\text { IV-V } \\
\text { floors }\end{array}$} & \multirow{2}{*}{$\begin{array}{r}\mathrm{V} \\
\text { fills }\end{array}$} \\
\hline & & fills & middens & Drain & floors & demol. & & \\
\hline Carychium spp. & & & 2 & 10 & & & & \\
\hline Gyralus albus & & & & 5 & & 6 & & \\
\hline Succinea / Oxyloma spp. & & & & 1 & & & & \\
\hline Cochlicopa spp. & & & 9 & 79 & 1 & 9 & & \\
\hline Vertigo antivertigo & & & 1 & & & & & \\
\hline Lauria cylindracaea & 1 & & 222 & 238 & & 44 & & 13 \\
\hline Vallonia pulcella & & & & 7 & & 2 & & \\
\hline Vallonia spp. & & & 1 & 7 & & 2 & & \\
\hline Discus rotundatus & 5 & 1 & 168 & 217 & 2 & 47 & 1 & 9 \\
\hline Vitrina pellucida & & & 2 & 3 & & & & \\
\hline Vitrea spp. & 1 & & 35 & 95 & & 79 & 7 & 2 \\
\hline Aegopinella nitidula & & & 22 & 16 & & 6 & 1 & \\
\hline Oxychilus spp. & 3 & & 96 & 229 & & 47 & 5 & 3 \\
\hline Clausilia bidentata & & & 1 & 3 & & 13 & & \\
\hline Balea perversa & 1 & & 111 & 14 & & 2 & & \\
\hline Clausiliidae & & & 4 & & & & & \\
\hline Trichia hispida & & & 2 & 2 & & & & \\
\hline Cepaea / Arianta spp. & & & 1 & 1 & & 1 & & \\
\hline Sample vol. (litres) all contexts & 10 & 2 & 161 & 133 & 25 & 8 & 23 & 12 \\
\hline Apices per litre all contexts & 1.1 & 0.1 & 8.7 & 5.1 & 0.1 & 33.3 & 0.8 & 2.3 \\
\hline
\end{tabular}

Mussels may have been collected from rocks in estuaries. Although a great variety of species were identified from Dundrennan Abbey, their low numbers may reflect a lack of preference for marine molluscs in the monks' diet.

Mortar-related shell fragments derived from most of the sieved samples. The marine shells used in the mortar component were from sand burrowing species which could easily have been dug out of sandy beaches. Marine shell left as food debris may also have been used for the mortar mixture as the most common species present in the mortar-related shell fragments, again, are common cockle and mussel.

\subsection{Terrestrial and freshwater molluses}

Terrestrial and freshwater mollusca are generally studied in order to investigate the nature of the local environment in which the animals lived. In the case of Dundrennan Abbey the basic environment is clear: the snails were living in a large collection of mortared stone buildings which experienced periods of decay, refurbishment and demolition. The intention in studying this assemblage is therefore to attempt to add some detail to this broad picture, in particular the conditions in the great drain.

\subsubsection{Methods}

Shells of terrestrial and freshwater molluscs were retrieved from bulk sediment samples during sorting of flots and retents; flots were collected in a $300 \mu \mathrm{m}$ mesh sieve and retents in a $1 \mathrm{~mm}$ mesh. A mesh size of $500 \mu \mathrm{m}$ is recommended for the retrieval of terrestrial mollusc shells but, because the majority of shell apices floated, the recovery technique is judged to be adequate. In addition to the shells recovered from sediment samples, a very few shells of large species were hand-retrieved during excavation. All shell apices were identified to species, genus or family level (nomenclature follows Kerney 1976). In general specific identifications were not attempted for taxa where this would prove time-consuming or add little to the interpretation of the assemblage. Specimens of Cochlicopa are probably all C. lubrica and Vitrea appears to be all $V$. contracta. Of the three possible 
species in the genera Cepaea and Arianta, only $C$. nemoralis was positively identified from handretrieved specimens.

\subsubsection{Results}

Shells were widely distributed through the excavated sediments and were recovered from 30 of the 42 bulk samples processed by AOC Archaeology Ltd. In most cases shells were present in very low concentrations; only 11 samples contained more than two apices per litre of sediment and this may account for the lack of shells from certain small samples. The incidence of species in the assemblage is given by Table 9 .

\subsubsection{Discussion}

Taking the assemblage as a whole, it is dominated by taxa typical of disturbed but shaded habitats associated with stone buildings or rubble. Five taxa account for most of the shells: Lauria cylindracea, Discus rotundatus, Vitrea spp., Oxychilus spp. and Balea perversa. Comparison of those assemblages with more than 100 apices reveals two groups with distinct compositions. The Period IV midden deposits are dominated by Lauria with subordinate Discus, Oxychilus and Balea perversa. The Period IV and V drain fills are dominated by a mixture of Lauria, Discus, Vitrea and Oxychilus. Lauria and Balea exploit rock faces and stone walls (Kerney \& Cameron 1979) and their relative abundance in the first group reflects the presence of stone wall faces around these deposits. The relative abundance of Discus, Vitrea and Oxychilus in the second group matches assemblages from either a rubble or more strictly subterranean environment (Evans \& Jones
1973). As these are drain fills, this result is not unexpected.

The assemblages from the drain fills, although dominated by the characteristic subterranean taxa of local origin, also contain rarer examples of taxa that suggest water/marsh conditions or water transport of shells. The most obvious example is Gyraulus albus, a species of ramshorn snail that is widespread in all types of freshwater, flowing and still. This occurs in low numbers in four drain-fill assemblages and presumably inhabited the watercourse that supplied the drain. Three other taxa in the drain-fill assemblages, none of them strictly aquatic, may also reflect the presence of flowing water. There is a single shell of Succinea/Oxyloma, both genera typical of marsh or wet grassland. Four contexts contain shells of the genus Vallonia which is clearly $V$. pulcella in all examples identified to species level; this is also a species that inhabits wetland. Finally, all except one of the shells of Carychium were found in drain fills. These were not identified to species level but could be the marsh species $C$. minimum rather than the strictly terrestrial $C$. bidentatum. These three marsh species are unlikely to have lived in the covered drain but could easily have been washed into it from its banks, upstream of the abbey. A fourth marsh species, Vertigo antivertigo, is represented only by a single shell in a midden deposit; there is no obvious explanation for its presence.

The abundant fragments of lime mortar in many of the excavated sediments have created calcium-rich, high $\mathrm{pH}$ conditions suitable for the preservation of mollusc shells. Therefore the general rarity of shells must indicate that few became incorporated into the sediments. The most likely explanation of this is that the drain sediments and associated middens accumulated rapidly, and only in a few cases did these remain accessible long enough for snails to accumulate. 


\section{Insects by Harry Kenward}

Insect and other invertebrate remains from sediment samples were submitted for identification and cataloguing, to ascertain whether they were ancient or modern and, if ancient, to establish their interpretative value. The samples were principally from the great drain and associated middens.

A series of small groups of invertebrate remains was identified. The material was generally of little interpretative significance and in some cases clearly of modern origin. The insects with more-or-less entire appendages and the Euophryum weevil (a wood-borer from Australasia) are certainly modern. Indeed, the entire fauna may be intrusive.

The remains from the great drain were diverse and rather abundant (see 4.7.2 Great drain fills). They fell into two groups: free remains and a single rounded compressed pellet measuring about $21 \mathrm{~mm}$ by $13 \mathrm{~mm}$ by $5 \mathrm{~mm}$. The latter was composed of centipede (Lithobius sp.) and woodlouse (Oniscus asellus) remains, some still associated as almost entire individuals and some separated. The quantities of the two species were about equal. This was clearly a pellet or dropping from an insect-feeding vertebrate. Possible sources are frogs and toads, mammalian insectivores (perhaps hedgehog), and birds. The lack of a fine matrix perhaps indicates a bird pellet rather than faeces, unless some process has differentially removed fine matter. In contrast, the species present suggest a ground-feeder, perhaps a large amphibian or (more probably) a hedgehog. There were no obvious indications that this material was of recent contaminative origin, nor that it was ancient. The presence of Megaselia fly puparia indicate some kind of decaying matter, but it is suspected that the invertebrate corpses themselves might have provided food for these very catholic flies.

Some of the woodlouse remains were well preserved, but others, both in the pellet and the free material, showed characteristic decay which casts light on the puzzle of the rarity of fossils of these animals in most assemblages preserved by anoxic waterlogging. The cuticles were clearly eroded. Some areas had an appearance reminiscent of very decayed oyster shell, and were extremely fragile and crumbly. Such fossils would undoubtedly disappear from the record very easily. It was also observed that some of the centipede remains appeared to have mineral deposits forming on them, perhaps an early stage of mineral replacement. 


\section{Burnt Fuel Remains by Ruby Céron Carrasco and Coralie Mills}

Samples of burnt fuel residues were examined both by the naked eye and under low power binocular microscopy. There are two types of probable fuel residue from the site. One is a fused mixture of organic materials (from a range of contexts in Periods I, IV and V) and the other, less frequent, type is represented by fragments of probable burnt coal (from midden deposits in Period IV-V).

The burnt, fused, organic remains are formed of a mixture of charred plant remains, including stems, straw (some of which seems to contain insects), twigs, roots and wood. The remains are mostly highly friable and appear as dark-coloured lumps of variable size, ranging from $0.5 \mathrm{~mm}$ to $30 \mathrm{~mm}$ on the longest axis. The texture and appearance is variable, even within the same fragment, sometimes being comparable to compressed ash or otherwise appearing to be somewhat glassy and solidified. The latter type is slightly vesicular and of vitreous appearance which may be explained by the fact that straw has a high silica content. There are no clear differences between contexts in the nature of the material.

Some remains are interpreted as representing burnt fuel of mixed composition. This could derive from such sources as byre waste, dung, peat and firewood. The fusion of the different materials suggests that more than one fuel type was being used to feed the same fires. An alternative explanation is that the material result from the conflagration of a building or buildings constructed with various organic materials. However, it has been suggested that the appearance of the glassy, vesicular component indicates burning under moderate and controlled temperatures (pers comm., A Clydesdale).

Coal was represented in a few Period IV contexts only. 


\section{General discussion by Gordon Ewart}

The results of the excavation have been expressed as a simple sequence of building, repair and decline, but clearly also demonstrate the evolution of the house within key historic periods. In discussing the significance of the findings, evidence of this evolution is reviewed in terms of specific episodes of construction work on the site. There are three historical periods against which the episodic development of the buildings within the abbey complex can be best reviewed, in as much as prevailing conditions enabled the abbey to be successful, and which also more acutely prescribed and determined the scale and nature of the changes to the buildings.

\subsection{Colonisation and early success: 12 th to late 13th centuries}

As suggested above the foundation of the abbey by Fergus, Lord of Galloway in 1142 is likely to have been inspired, at least in part, by David I of Scotland's support for the Cistercian Order. However, it should be borne in mind that Dundrennan was essentially part of the Lordship of Galloway, whereas the Border Abbeys of Kelso, Jedburgh and Melrose were all seen by their royal patron as being at the heart of his kingdom. The king had close associations with England and these latter foundations were intended to serve territories on either side of what was to become the Scottish border. Their subsequent role as sites close to the frontier between two hostile powers was not a factor, therefore, in their original foundation. In contrast, Dundrennan was seen as an expression of the aspirations of an independent lord, representing a distinct territory, in Galloway. With the emergence of Fergus during the early decades of the 12th century, a line of succession was established for Galloway, culminating with Alan (d.1234), himself buried at Dundrennan. Over almost a century Dundrennan was closely associated with Fergus and his heirs, although it was Fergus himself who was the most pious and generous to the foundation, granting it extensive lands and estates, reflected in the later parish of Rerrick. It is probable that concern for the welfare of his immortal sole was a prime concern for Fergus, but as a lord and patron to the abbey, he was an individual who considered himself of the same degree of nobility as the royal house itself. The scale of the donations to Dundrennan at once identify Fergus as a man of considerable means, as well as sincere piety.

The sequence of building and conversion revealed in the excavations indicates how the independence of the Cistercian Order initially functioned alongside, and later became a function of, Gallovidian interests from the 12 th to the 16 th century. The family of Fergus were of Hiberno-Norse stock, and they appear to have owed much of the structure of their lordship of Galloway to earlier Celtic customs. They depended on a strong and active fleet for the maintenance of their power-base, and in their campaigns against Norse and mainland Irish neighbours. Alan of Galloway was regarded as the greatest warrior of his time, and as a successful ruler was able to protect Gallovidian interests and secure its frontiers after the various attempts to invade by English and Scottish forces. It was only his failure to produce a legitimate male heir which brought the line of Fergus, and with it that of the early lords of Galloway, to an end. The consequent uncertainty and political instability which developed, as factions strove to lay a claim to the lordship, heralded not only the demise of the lordship of Galloway, but the onset of war between England and Scotland. This larger conflict subsumed the particular interests of the ancient lordship of Galloway, as many of the active participants, the Baliols, de Lacys, Stewarts and Bruces, had strong connections with southwestern Scotland, and the territorial cohesion of the early lordship was soon lost.

It is significant therefore that the burgeoning success of the early lords, seen in Fergus and his heirs, coincided almost exactly with the development of the abbey up until the completion of the major building works of Period II ( $c$ 1230-1320). The prestigious rebuilding work within the nave and chapter house in particular reflects the ongoing success of the Cistercian Order, as the conversi and increasing revenue enabled expensive reinvestment in the fabric of originally more austere buildings. The most dramatic examples of this period of high-quality building work found during the excavation comprise rooms 4 and 5 (see 4.3.2 Room 4 and 4.3.3 Room 5), featuring fine architectural details, both in situ and implied by the quantities of worked stones from the stone vaulting. Within the typical Cistercian plan, these rooms are likely to represent the monks' and novices' day rooms, respectively (illus 5). The relatively high quality of the architecture in rooms 4 and 5 can be compared to that of the more elaborate extant work in the chapter house, giving the Period II east range a very impressive appearance. After the church, the chapter house was the most important structure in the hierarchy of monastic buildings, followed by the refectory.

The abbey's prosperity could only be achieved, however, within a secure socio-political context, and the requirements for effective trade and estate management saw increased economic integration with the local area. It has been argued that disciplinary 
measures taken against superiors of the house during the 13 th century were inspired by their affiliation with the interests of Thomas of Galloway, the illegitimate son of Alan. Whatever the facts of this particular matter, it is certain that recruitment by the Cistercians within Galloway would have given the community a particular social allegiance which would not have impinged on its European network of interests with other houses of the Order. The choice of Dundrennan for the burial place of Alan of Galloway confirms this central role for the abbey as the pre-eminent foundation for his dynastic group. It in turn became part of the landscape of secular power, alongside early castle sites such as Buittle, the Motte of Urr, Threave and Kirkcudbright, which formed an important defensive line for the early lordship. The abbey resides within a landscape rich in early medieval prestige sites, reflecting the power and status of its patrons, yet within its wooded valley it remained sufficiently secluded to meet the requirements of the Order.

In considering to what extent local factors, other than the provision of sufficient economic resources and physical security from attack, influenced the design and character of the Cistercian planned architecture, comparison with Irish foundations is enlightening. It is probably as appropriate to review Dundrennan in an Irish/western seaboard context as it is in relation to Anglo-Norman influences via Rievaulx, given the role of St Malachy (see 3. Historical context) and the distinct separation between the lordship of Galloway and the rest of mainland Scotland. Yet there is little which can be identified with native building traditions in the architecture of contemporary Irish Cistercian houses. Any comparisons therefore between Dundrennan and Irish houses of the Cistercians reside within the motives of Irishbased patrons who, like Fergus, favoured the Order in their attempts to rationalise the existing systems of Celtic Christian observance. In the case of Galloway, the importance of Whithorn and the veneration of St Ninian represented well-established Christian interests which the Cistercian Order was able to exploit to its benefit, and the later (13th-century) Bishops of Whithorn display a distinct Cistercian bias. In due course, with the foundation of its daughter houses at Glenluce and Sweetheart, Cistercian interests were extended during the 13th century, allowing Dundrennan increased influence in greater Galloway, probably as part of an established tradition of pilgrimage to Whithorn. The success of the Order in Ireland and Galloway may be regarded in part as a product of the existing and welldeveloped Christian tradition of these areas, onto which the highly centralised administrative and economic regime of the Cistercian order could be superimposed.

The hybridised nature of the government of Galloway - a 'kingdom within a kingdom' - where feudal duty and traditional overlordship were coincident, is also paralleled by the colonisation of Ireland by Anglo-Norman lords. It is possible that alongside the need to fulfil the criteria for the enclosed, ascetic life of the community in the 12th century, the broader life of such a community within a Celtic society would inevitably influence the character of that community. The brethren at Dundrennan may have existed within a self-defining spiritual community over the first 100 years of the abbey's life. With the inevitable increase in integration with the local community through trade, and also through the progressive dilution of original ideals, the character of the house may well have owed as much to western seaboard culture as it did to rules and policies imposed from the mother house. Existing traditions of pilgrimage and trade, alongside the links with France and Spain and combined with the independence of Galloway, remained consistent factors in the later history of the house, and of the area as a whole.

Local factors apart, and in keeping with general Cistercian trends prior to the later 14th century (Period III), the house benefited from the increased wealth generated within the Order as a whole, particularly by the exploitation of the conversi. At Dundrennan the lay brothers' dormitory is thought to have extended along the west range, and the increased size of the community is certainly implied by the changes to the great drain. This was modified in Period II to serve a variety of waste-disposal functions, probably centring on the lay brothers' ranges further to the west (see 4.3.6 Great drain modified). Prestige building works within the nave and the chapter house are seen as part of the general completion of the abbey buildings in stone (Period II). Although the excavated evidence for Period I was slight and the work may well have progressed in stages over an extended period, a distinction is maintained in the archaeological account between an earlier cloister layout and its completion (Period II).

From colonisation to the mid 13th century, the gradual extension and refinement of the abbey, featuring an important example of Early Gothic in Scotland, was facilitated by the continuity of the lordship of Galloway.

\subsection{Remodelling in the 14th- century}

The evident remodelling of Dundrennan in the 14th century fits well with our knowledge of the religious and economic conditions which prevailed at the time. The monasteries of Galloway suffered much during the wars with England. In 1299 the abbeys of Dundrennan and Sweetheart petitioned Edward I on a number of issues including confirmation of their lands 'held by charter of their founder and others' and for 'relief from seignurages and talliages imposed contrary to their franchise and founder's charter, to their great impoverishment, whereby they can neither maintain themselves, the service of God, nor the alms of the house' (Calendar II, no. $1123,286)$. It is not known when these taxes were imposed, but it was undoubtedly the case that their 
collection in time of war must have placed a substantial burden on monastic resources. The abbeys suffered at the hands of both English and Scottish troops. The abbot of Sweetheart sought 'restoration of 8 sacks of good wool taken for the king Edward I by Sir Harsculf de Cleseby out of a grange at Holm Cultram where they had placed it for safety from the Scots'; and both Dundrennan and Sweetheart also sought reparation for their respective destruction and burnings in the war - the abbot of Sweetheart estimated that the destruction cost his abbey $£ 5,000$, whereas the abbot of Dundrennan sought $£ 8,000$ (ibid). Unfortunately, the exact nature of the damage is unknown; on one hand it may have referred to destruction wrought on the buildings of the monastic complex itself, on the other, it may have referred to the burning of crops and the destruction or spoilation of monastic granges and food reserves. Moreover, at the outbreak of hostilities the monks of Dundrennan were ejected from the abbey's Irish possessions 'for no other reason than that they were Scots' (Calendar V.i, no. 2414, 479). Dundrennan would have lost all income from those lands.

While it is true to say that the wars with England had a detrimental affect on Dundrennan and the abbey's ability to successfully exploit its agrarian and economic resources, the decline in the monastery's fortunes had set in well before the 1290s and involved a series of factors apart from the dislocation caused by war. The number of lay brothers in the Order (the normal workforce of the abbey) declined during the 13th century to such an extent that by 1300 they no longer played a role in monastic organisation. By the 14th century the great age of monastic construction and endowment was at an end. The huge blocks of territory such as those which had been donated to the abbeys in the 12 th and 13 th centuries were no longer available. More importantly, the nobility no longer looked to monastic patronage as a means of demonstrating their piety or noble status and, consequently, donations to the monasteries declined markedly over the course of the 13 th century.

Furthermore, after 1350 Scotland experienced a period of general economic decline which must have had an appreciable influence on monastic economy: in a revision of land values undertaken in 1366 the Church's total assessment was reduced by $37 \%$ ' (Grant 1984, 95). After 1400 income from wool also fell, and considering the importance of wool as the chief monastic trading commodity, it is perhaps safe to assume that the abbeys would have experienced a dramatic fall in income.

Overall, an increasing number of financial burdens during the 13th century, the loss of lay brothers (leaving areas of the monastic complex on the west side of the cloister underused) and the dislocation and destruction brought about by war with England led eventually to the necessity for remodelling of the monastic buildings in the 14th century. Of course, there is evidence that at least one French stonemason worked in Galloway in the years around 1400 , and it is tempting to think that he may have worked at Dundrennan, although this cannot be proven. John Morow of Paris is known from an inscription at Melrose Abbey where he listed his name, place of birth and the places where he had worked in Scotland. These included St Andrews, Glasgow, Melrose, Paisley, Nithsdale and Galloway.

The precise causes of damage which prompted the repairs to the latrine block are not known, but there is good circumstantial evidence to suggest that it was the destabilisation of the south and east façades of the Period II buildings in this part of the site which necessitated those measures. The east and south walls of the two-storey latrine block appear to have been located at the extreme edges of the preferred building platform for the cloister. Shallow terracing is evident in a progressive step-system along the rooms of the south range, and also leading down from the chapter house towards the south-east corner of the cloister. The net effect of these shallow steps is an overall drop in level between the cloister and the floor of room 5. One of the important roles of the south and east walls of the latrine block therefore was to retain the weight of masonry coming from both directions (west and north) and to revet the building terraces. In Period III it is clear that the additional buttresses, and room 12, served in part to strengthen the south side of the latrine block, as well as to mitigate the loss of a significant part of room 5 and the storey above (see 4.4.3 Room 12). In functional terms these measures can be seen as an attempt to reduce the east/west alignment by a critical amount, and to reinforce a north/south alignment for this, the junction of the east and south ranges. The natural flood plain of the meandering river to the east was clearly artificially enhanced to receive the stone ranges. The present boggy nature of the terrain to the east of the abbey and the indications that terracing was also required for secondary abbey buildings to the east suggests that drainage in this area was always a difficulty (see 5. Geophysics and trial trenches). Later agricultural evidence from the 17 th and 18th centuries suggests that the ground was extensively top-dressed to alleviate this tendency. The presence of a likely monastic pond towards the angle of the river bend to the east of the site also tends to confirm the natural propensity of the area to flooding.

There was a need to carry out the repairs outlined above, therefore, but prevailing economic factors at the end of the 14th-century were apparently far from conducive to extensive rebuilding. The effects of almost 100 years of war with England, in terms of loss of trade, as well as damage to the abbey buildings themselves, the effects of the Black Death after 1350 , and the loss of a free labour force in the form of the conversi, all combined to deplete the resources of the house and the Order in general during the later 14 th century. The needs of the reduced community were very different, therefore, from those of the earlier colonists.

The character of the Order towards the beginning of the 15th century changed, being more inclined 
towards the 'individual' in terms of residential requirements in the absence of a permanent contingent of servants. Consequently the great communal spaces of the refectory and dormitory were of declining importance. The tendency towards individual accommodation does not, however, necessarily imply any decline in the conduct of the brethren, nor the dedication of their faith. However, at this time the new house of Stewart - in the person of King Robert II - saw advantages in maintaining, or in recreating a stable framework for the re-establishment of trade and social order after the relative chaos of the decades of the Wars of Independence. From this perspective there would have been mutual advantages in the preservation of this and other Cistercian communities. The depredations of war and disease had affected royal resources considerably and it is testament to the efficient organisation of the king's vastly reduced revenues that the work at Dundrennan and other great buildings, both secular and religious, was commissioned under Robert II. The close mutual interests of the royal house of Scotland and the Cistercian Order were further cemented by their mutual adherence to the Avignon Papacy during the Great Schism. As an Order with French origins, the Cistercians plainly had to affiliate themselves with a French Pope, a policy which was also followed by the Scottish kings, in contrast to their English counterparts.

So in considering the changes made during Period III, they may well reflect straightforward maintenance, but they occurred at a time when the evolving interests and character of the Order could be accommodated by the adaptation of the earlier monastic plan. The changes in day-to-day routine are defined through the progressive sub-division of the rooms excavated, toward less and less communal access and function, even ultimately replacing communal latrines with cruder, but separate external garderobes (see 4.4.4 Great drain and garderobes). This trend is evinced on most monastic sites, but it is all the more marked at Dundrennan, given the extreme asceticism and regularity of the original Cistercian regime, and consequent impact on its 12 th- and 13th-century layout. Thereafter, an important role for Dundrennan in both regional and national affairs was maintained, by adapting to the requirements of a new regime.

\subsection{Commendatorship}

The role of abbatial estates as potential sources of revenue and political advantage was an increasing aspect of the later years of the 15th century. In addition, the practice of appointing lay administrators recruited from the local nobility - or commendators became well established in the early decades of the 16th century. This trend, along with the gradual decline of numbers of monks within the monastic houses in general, heralded the demise of the monastic tradition. The progress of the Reformation in
Scotland did not, however, echo the cathartic changes of the English Reformation, and the role of the abbeys again reflects a gradual, rather than a dramatic shift of emphasis, from serving the needs of a dwindling community of monks to those of a landlord in residence. Despite the fact that the abbey as a monastic institution came to an end with the Reformation of 1560, some of the monks continued to live there alongside successive commendators.

The long-standing trade links with France and Spain emanating from the great network of associated houses thrived throughout the 16th century, particularly in the movement of wine and luxury goods. It was only with the Union of Crowns in 1603 that the trade between mainland Europe and southwest Scotland diminished to any significant degree. This economic background, coupled with the maintenance of monastic estates, enabled the commendators at Dundrennan to prosper and to develop a particular political agenda, based on their Catholic faith.

The changes enacted at Dundrennan show how the large open spaces in the ranges were now subdivided further, given timber floors and ultimately blocked-off, creating cellars, arguably for the storage of goods deriving from the still intact, formerly monastic estates around the abbey (see 4.6.1 Rooms 1 and 3; and 4.6.2 Rooms 4 and 6). Edward Maxwell, who was commendator between 1562 and 1598, may have lived at the abbey, at least until his marriage. The wealth of 16th-century deposits found in association with the sub-divided warming house and novice's day room could well date from this period. It is known that Edward Maxwell had a considerable household of servants, who in part were maintained to protect his own livestock, pastured on the old abbey estates. Edward in turn was an active Catholic in the political arena alongside his father, Sir John Maxwell of Terregles, 4th Lord Herries. Dundrennan was valued by the Maxwells to the extent that his appointment as commendator had occurred when he was a minor, to ensure that the estate remained within family hands. The importance of the house of Dundrennan and its estates is reflected by the findings of the excavation. Despite the high degree of disturbance, due primarily to the effects of demolition and stone robbing programmes of the 17th and 18th centuries, the continued occupation of the site throughout the 16th century is reflected by the assemblages retrieved.

To conclude, a relatively cursory examination of the archaeological sequence at Dundrennan has provided a useful addition to the corpus of archaeological evidence relating to the Cistercian Order in Scotland. The results represent both a sequence of building adaptation within the abbey and also its changing role within a wider historical context: the condition of the Cistercian house at Dundrennan was critical both to the community within its walls and to the wider community of Galloway. The combined motivations of an imposed, alien model (the Cistercian foundation), fully formed and 
independent, alongside the political aspirations of its patrons and ultimately its owners, engendered the progressive building programmes identified as Periods I-V. The abbey buildings certainly ceased to be of significance with the establishment of the temporal lordship in 1606, and their swift demolition soon followed (other than the church) as most of the buildings served no useful function within the new parish of the Reformed church. With the archaeological investigations of the site during the 19th and earlier 20th centuries, the abbey was once again heralded as a great cultural and community resource. 


\section{Acknowledgements by Gordon Ewart}

The author would like to thank all those specialists who contributed to the success of the project, both in the field and during the compilation of this report. Special thanks should go to the field staff: J Triscott, P Sharman, D Stewart, D Montador, D Connolly, F Baker, A Levy, D Murray, A Radley and to GeoQuest Associates for the geophysical survey. David Caldwell, Nigel Ruckley, Nicholas McQ Holmes, deserve special mention for their helpful advice and general assistance in the interpretation of the results of the fieldwork, as well as in the identification of the various assemblages. I would like to thank Coralie Mills and her team from AOC Archaeology Ltd and Bill McQueen for their support and enthusiasm for the project during the postexcavation period, and for guiding the author to reasonable conclusions. Thanks also to Doreen Grove, Chris Tabraham, Richard Welander and Richard Fawcett of Historic Scotland for their advice, encouragement and support. Finally, I would like to thank my colleagues Andrew Dunn and Andrew Hollinrake for their efforts in bringing this paper to completion, and those people in Galloway who helped make the excavation such an enjoyable experience - John Anderson, Lachie, Bill (Custodian), Bill (Orchardton) and all at The Smuggler's Arms, Auchencairn.

The project was funded throughout by Historic Scotland. 


\section{Bibliography}

Anson, P F 1950 Scots Fisherfolk. Banffshire.

Black, M (ed) 1993 A Taste of History: 10,000 years of food in Britain. London.

Boyd, W 1988 'Cereals in Scottish antiquity', Circaea 5(2), 101-10.

Boyle, P, Pierce, G \& Watt, J in press 'Guide for the identification of premaxillae and vertebrae of the fish from the North Sea'. Aberdeen.

Brooke, D 1994 Wildmen and Holy Places: St Ninian, Whithorn and the medieval realm of Galloway. Edinburgh.

Calendar Bain, J (ed) 1881-84 Calendar of Documents Relating to Scotland in the Public Record Office and The British Library. Edinburgh.

Campbell, A C 1989 Seashores and Shallow Seas of Britain and Europe. Hamlyn, London.

Carter, S 1992 [unpubl] St Boniface: Mollusc shell. Edinburgh [ = AOC Archaeology Ltd technical report].

Christie, A 1914 The Abbey of Dundrennan. Dalbeattie.

Cook, G H 1961 English Monasteries in the Middle Ages. London.

Daniel, W 1978 The Life of Ailred of Rievaulx. Oxford.

Dickson, J H \& Dickson, C A 1996 'Ancient and modern occurrences of common fig (Ficus carica) in Britain', Quaternary Science Reviews $15,623-33$.

Emery, J 1976 European Spoons Before 1700. Edinburgh.

Evans, J G \& Jones, H 1973 'Subfossil and modern land snail faunas from rock-rubble habitats', $J$ Conchology 28, 103-29.

Grant, A 1984 Independence and Nationhood: Scotland 1306-1469. London.

Graves, C P 1995 'Window glass', in Lewis J \& Ewart G, Jedburgh Abbey: the archaeology and architecture of a Border abbey, 110-113. Edinburgh [ = Soc Antiq Scot monogr ser 10].

Groves, $\mathrm{R}$ forthcoming 'Animal bones', in Dixon, $\mathrm{P}$, O’Sullivan, J \& Rogers, I Jedburgh Friary: excavations 1983-85 and 1990-91. Edinburgh [ = Scottish Trust Archaeol Res monogr ser].

Haggarty G \& Will R 1996 'Pottery', in Lewis, J, 'Excavations at St. Andrews, Castlecliffe, 1988-90', Proc Soc Antiq Scot, 126 (1996), 60588.

Hamilton-Dyer, S 1994 'Bird remains', in McCormick, F, 'Excavations at Pluscarden Priory, Moray', Proc Soc Antiq Scot, 124 (1994), 391-432.

Holden, T G 1995 [unpubl] 'Plant remains', in Duffy, A, 'Dundrennan Abbey post-sorting assessment report for Kirkdale Archaeology'. Edinburgh [ = AOC Archaeology Ltd technical report].

Jones, A K J 1991 [unpubl] Fish Remains from Freswick Links, Caithness. York [ = PhD dissert, University of York].

Kerney, M P 1976 Atlas of the Non-Marine Mollusca of Britain and Ireland. Cambridge.

Kerney, M P \& Cameron, R A D 1979 A Field Guide to the Land Snails of Britain and NorthWest Europe. London. Collins.

McCormick, F 1994 'Animal remains', in McCormick, F , 'Excavations at Pluscarden Priory, Moray', Proc Soc Antiq Scot, 124 (1994), 391-432.

McCormick, F 1996 'Mammal bones', in Lewis, J H, 'Excavations at St. Andrews, Castlecliffe, 1988-90', Proc Soc Antiq Scot, 126 (1996), 60588.

McCormick, F 1997 'Mammal bone tables', in Driscoll, S T \& Yeoman, PA, Excavations within Edinburgh Castle in 1988-91, microfiche 2:C1-D3. Edinburgh [ = Soc Antiqs Scot monogr ser 12].

McCormick, F forthcoming 'Mammal bones from Rattray Castle, Aberdeenshire'

MacGibbon, D \& Ross, T 1896-97 The Ecclesiastical Architecture of Scotland from the Earliest Times to the Seventeenth Century, 3 vols. Edinburgh.

Moreno-Nuno, M R 1994a Arqueomalacologia: identificacion de moluscos. Madrid [ = Informe No. 1994/18. Laboratorio de Arqueozoologia. Informe tecnico. Universidad Autonoma.]

Moreno-Nuno, M R 1994b Arqueomalacologia: cuantificacion de moluscos. Madrid [ = Informe No. 1994/19. Laboratorio de Arqueozoologia. Informe tecnico. Universidad Autonoma.]

Robinson, D 1987 'Botanical remains', in Holdsworth, P (ed), Excavations in the Medieval burgh of Perth 1979-81, 199-209. Edinburgh [ = Soc Antiqs Scot monogr ser 5].

Rosello-Izquierdo, E 1988 'Contribucion al atlas osteologico de los Teleosteos Ibericos: dentario y articular', Coleccion de estudios 14. Ediciones de la Universidad Autonoma de Madrid.

Scott, J G 1988 'The origins of Dundrennan and Soulseat Abbeys', Trans Dumfries \& Galloway Natur Hist \& Antiq Soc, 63 (1988), 35-44.

Shirley, G W 1926 'Birds mentioned in the Acts of Parliament of Scotland 1124-1707', Trans Dumfries \& Galloway Natur Hist \& Antiq Soc, vol 3 [third ser], (1924-25), 15-25. 
Silver, I A 1969 'Ageing of domestic animals', in Brothwell, D \& Higgs, B (eds), Science in Archaeology, 283-302. London.

Smith, J A 1877 'Notes on 'kitchen middens' recently discovered in the monastery and the nunnery on the island of Iona', Proc Soc Antiq Scot, 12 (1876-7), 103-177.

Steane, J M \& Foreman, M 1988 'Medieval fishing tackle', in Aston, M (ed), Medieval Fish, Fisheries and Fishponds in England, 137-81 Oxford [ = BAR Brit Ser 182(i)].

Stevenson, J 1991 A Medieval Chronicle of Scotland: the Chronicle of Melrose. Lampeter.

Symon, J A 1959 Scottish Farming. Edinburgh \& London.

Thomson, J 1845 'Parish of Rerrick', in Gordon, J (ed), New Statistical Account of Scotland, vol. IV, 354-68. Edinburgh \& London.
Tobin, S 1995 The Cistercians: monks and monasteries of Europe. London.

Tutin, T G, Heywood, V H, Burges, N A, Moore, D M, Valentine, D H, Walters, S M \& Webb, D A (eds) 1964-1980 Flora Europaea, vols 1-5. Cambridge.

Tylecote, R F 1972 'A contribution to the metallurgy of 18th- and 19th-century brass pins', Post- Medieval Archaeol, 6 (1972), 183-91.

Von den Dreisch, A 1976 A Guide to the Measurement of Animal Bones from Archaeological Sites. Peabody.

Wheeler, A 1978 Key to the Fishes of Northern Europe. London.

Wheeler, A \& Jones, A K G 1989 Fishes. Cambridge [ = Cambridge Manuals in Archaeology].

Williams, D 1973 'Flotation at Siraf', Antiquity, 47(1973), 198-202. 


\section{Index}

Abbey Burn 3, 5

harbour 5

agriculture $3,26,57,85$

post-medieval 37

rig \& furrow 37

Alan, Lord of Galloway 8, 82, 83

architectural details 18, 82

fragments 50 , Table 1

masons' marks 50, 51, Table 2

Ardchattan Priory, Argyll 76

aumbry/recess 18, 24

Balliol family 82

bead, copper-alloy 45

Beauly Priory, Inverness-shire 76

belt loop, iron 44

bird bones 73, Table 6

domestic fowl 71

merlin 73

wild 26,73

Black Death 84

bones, see birds, fish, mammals

gnawed by cats or dogs 71,73

Bruce family 82

building periods:

Period I 9-12, 15, 83

Period II 9, 12, 15-20, 82

Period III 9, 18, 20-26, 83, 84

Period IV 9, 26-31, 84

Period V 9, 31, 84

buttresses 18, 20, 24

cames, see windows

castle sites 57, 83 (Buittle, Motte of Urr, Threave and Kirkcudbright)

cellars 31,85

cereals 54, Table 3

barley 53

oats 53

wheat 53

chapter house 15,82

Christie, Reverend Alex, excavations 8, 12, 15

Cistercian Order in Scotland 3, 7, 8, 82, 83, 84-85

criteria for siting of abbeys $3-4,83$

diet 73,76

fishponds 76

lay brothers, see conversi

political influences $6-7,82-83$

Rule 83

supported Avignon Papacy 85

coins

James IV billon penny 36,45

Mary \& Francis hardhead 42

commendators \& ministers at Dundrennan 8, 85 accommodation 31 conversi (lay brothers) 7, 8, 82, 83, 84

decline in number 7,84

copper-alloy objects, see bead, fish hook, hinge, ingot, lace tags, nails, needle, pins, plaques

Coupar Angus Abbey, Perthshire 57

counters

slate 45

stone, decorated cross \& circle 47

cross head, carved stone 47

crustaceans $15,75,76$

David I 7, 82

day room, monks' 18,82

day room, novices' $9,18,82$

day stair 24

doorways $15,18,24,26$

bolts, iron, holes for 18

drain, great $15,24,26,31,83$

capstones $15,20,35$

contents 9

fill 36

geophysical survey 37

insect remains 36,80

drainage systems

agricultural 37,84

sub-floor 18, 20, 24, 26

Dundrennan Abbey, Kirkcudbrightshire, daughter house of Rievaulx

affected by Wars of Independence 84

annexed to deanery of Chapel Royal, Stirling 8

building periods, see separate entry

church becomes parish church 8,86

cloister 3

construction of manse 8,26

damage \& repairs 84

decline 8, 84-85

development $82-86$

$\operatorname{diet} 26,36,71,73,76$

drainage 84

estates owned and managed 7, 82, 84

example of Early Gothic 83

excavation, management \& conservation 8 , 86

foundation 3, 7-8

Irish connections 83

involved in political affairs 6

19th-century landscaping 8,37

plan of Abbey 6

pottery manufacture, stimulated local 39

private accommodation provided 26

siting 3-4

stone robbing from $3,9,12,20,24,26,85$

taxation 83-84

trade, see separate entry 
Edward I of England 7, 8, 83

Edward III 7

environmental evidence, see cereals, bones (birds, mammals, fish), crustaceans, insects, plants, soils

fauna, see birds, crustaceans, fish, mammals, molluses

Fergus, Lord of Galloway 7, 8, 82

fireplace 12,31

fish bones 15, 26, 75-76, Table 7

freshwater 75,76

lampreys 76

marine 75,76

bone in middens 36

fish hook, copper-alloy 44

floors

flagged 15

sprung timber 31,85

fruits 26 , Table 3

elderberry 53

fig 53

raspberry 53

fuel

charcoal 35

coal 81

organic materials 81

peat ash 36,81

turf 53

Galloway, Lordship of 7, 82, 83 and see Alan and Fergus of Galloway

gaming piece, stone 47

garderobes $30-31,35,85$

geophysical survey 37

glass, vessel, rim sherds and other 47

see windows for window glass

Glenluce Abbey, Dumfries \& Galloway, daughter house of Dundrennan 8, 83

grave slabs

reused as drain capping 26

sword motif on 26

grisaille, see window glass

handle? iron 45

harbour, Abbey Burn Foot 5

hearth 12,31

heel support, iron 42

hinge, copper-alloy 45

hot water bottle, ceramic 39

ingot, copper alloy/lead compound 44 analysis 42

ink pots, ceramic 39

insect remains 36,80

Ireland 7

Cistercian influence 83

Dundrennan property $7,8,84$

iron objects, see belt loop, handle, heel support, key, ring/quoit, spearhead

plate fragments 44 jar, ceramic, of hair restorer 39

Jedburgh Abbey, Roxburghshire (Borders) 48, $49,57,82$

Kelso Abbey, Roxburghshire (Borders) 57, 82

key, iron 42

lace tags, copper-alloy $42,44,45$

de Lacy family 82

latrine block 9, 15, 20, 24, 26

abandoned 30

repairs 84

lay brothers, see conversi

lead objects, see plaque, scriptum, seal, window cames

leather

shoes 45

traces in lace tags 42,44

Maitland, Adam of Dundrennan, conveys abbey to state care 8

Malachy, Archbishop and papal legate of Ireland 7, 83

mammal bone $26,57-81$, Table 4

bone in middens 36

butchery 57,71

cat 71

cattle 57

hare 71

marrow from 57,71

rodents 71

sheep 57 and see wool

manse, built on abbey site $3,8,26$

Mary, Queen of Scots at abbey 8

masonry $18,20,24,26$

masons'marks 50, 51, Table 2

Maxwells at Dundrennan 8, 85

Melrose Abbey, Roxburghshire (Borders) 7, 57, 82, 84

midden deposits 9, 31, 35-36

molluscs 77-79

marine $77-78$, Table 8

terrestrial \& freshwater 78-79, Table 9

Morow, John of Paris, stone mason 84

mortar 52

analysis 52

with shell 52, 77, 78

Murray, John, Earl of Annandale \& commendator of Dundrennan Abbey 8

nails, shoe, copper-alloy 45

needle, copper-alloy 42

Newbattle Abbey, Midlothian 76

pebble, see gaming piece

pigs 57

pillar bases 18,20

pins

copper-alloy $42,44,45$

silver 42,45

'pirlie pig' money box, ceramic 40

plant remains 53-56, Table 3, 54-56 
plaques

copper-alloy 44

lead 45

plaster 18, 24

analysis 52

platforms, building for structures 37, 85

Pluscarden Priory, Moray 76

pottery: periods 39; catalogue of illustrations 39-41

13 th century 20

14th century 9

late 15 th century 31

late 16 th to early 17 th century 31

Scottish medieval redwares 39

Scottish white gritty 39

Scottish post-medieval reduced wares 39

iron glaze 39

imported medieval 20

Saintonge, mid 13 th century to late 14 th century 39

French, Loire region, late 14 th century to 15 th century 39, 40

Spanish/Portuguese, late 14 th century to 15 th century 39,40

post-medieval imported 31

Beauvais stoneware 39

Martincamp flask 39

Raeren stoneware copies 39-40

later 19 th century 39

quarry stone 5

recess or aumbry 18,24

refectory

period I 9, 11

period II 15, 82

Reformation (1560) 85

Rerrick, modern parish comprises Dundrennan estates 7, 82

Rievaulx Abbey, North Yorkshire 7, 83

Ailred, abbot 8

ring/ring brooch, copper-alloy 44

ring/quoit, iron 44

Robert II 85

roofs and roofing

rib-vaulted 18, 50

slates 35

vaulted $18,50,82$

St Ninian 83

scriptum/stylus, lead 45 seal, lead 45

Selkirk, Earls of 8

sheep

farming 7,57

and see mammal bones

shoe fragments, leather 45

silver objects, see pins, spoon

slates

counter 45

roofing 35

soils analysed 36

spearhead, iron 44

spoon, silver, ficulate 42

Stewart family 82, 85

Stirling, Chapel Royal deanery annexed Dundrennan Abbey 8

stone objects, see counters, cross head, gaming piece

structures, temporary 9, 26; demolished (no 13), 910

Sweetheart Abbey, Kirkcudbrightshire, daughter house of Dundrennan 83-84

Thomas of Galloway, illegitimate son of Alan 83

timber structures

beam/post-frame 9,12

lean-to 26

trade $7-8,83,85$

England 6, 84

European markets 6, 17, 24

trade, imports

grain 7-8

pottery $20,31,39$

wine $8,39,85$

undercroft, see latrine block

Union of the Crowns (1603) 85

warming house (Rooms 8, 10) 9, 12, 20, 24, 26

Wars of Independence \& effect on monasteries 8 , 83-84, 85

water supply 3,5

weeds, in plant remains, Table 3, 54-56

Whithorn and pilgrimage 83

windows $18,24,31$

cames 42,45

glass $48-49$

grisaille 48,49

wool production $7,39,57$

income from 84 